\title{
DATA PRIVACY AND DIGNITARY PRIVACY: GOOGLE SPAIN, THE RIGHT TO BE FORGOTTEN, AND THE CONSTRUCTION OF THE PUBLIC SPHERE
}

\author{
ROBERT C. POST $\dagger^{\dagger}$
}

\begin{abstract}
The 2014 decision of the European Court of Justice in Google Spain controversially held that the fair information practices set forth in European Union (EU) Directive 95/46/EC (Directive) require that Google remove from search results links to websites that contain true information. Google Spain held that the Directive gives persons a "right to be forgotten." At stake in Google Spain are values that involve both privacy and freedom of expression. Google Spain badly analyzes both.

With regard to the latter, Google Spain fails to recognize that the circulation of texts of common interest among strangers makes possible the emergence of a "public" capable of forming the "public opinion" that is essential for democratic self-governance. As the rise of American newspapers in the nineteenth and twentieth centuries demonstrates, the press underwrites the public sphere by creating a structure of communication both responsive to public curiosity and independent of the content of any particular news story. Google, even though it is not itself an author, sustains the contemporary virtual public sphere by creating an analogous structure of communication.
\end{abstract}

With regard to privacy values, EU law, like the laws of many nations, recognizes two distinct forms of privacy. The first is data privacy, which is protected by the fair information practices contained

\footnotetext{
Copyright @ 2018 Robert C. Post.

$\dagger$ Sterling Professor of Law, Yale Law School. I am deeply grateful for the research assistance of Jeremy Buotte, Conor Clark, Nina Cohen, Samir Doshi, Jean-Philippe Foegle, Jesse Hogin, Bryn Lese, Bernat Torok, and Andrew Udelsman. I am fortunate indeed to have received helpful and constructive advice from Jack Balkin, Eduardo Bertoni, R. Howard Bloch, Frederik Zuiderveen Borgesius, Pablo Salvador Coderch, Jennifer Daskal, Anuj Desai, David Erdos, Krzysztof Garstka, Dieter Grimm, Amy Kapczynski, Daphne Keller, Leslie Kendrick, Antoni Rubi Puig, Artemi Rallo, Jeffrey Rosen, Timo Ruikka, Reva Siegel, Daniel Solove, Alexander Tsesis, Eugene Volokh, and Patrick Weil. Thanks also to my friend and guide, Paul Schwartz, without whom this never would have been written.
} 
in the Directive. These practices regulate the processing of personal information to ensure (among other things) that such information is used only for the specified purposes for which it has been legally gathered. Data privacy operates according to an instrumental logic, and it seeks to endow persons with "control" over their personal data. Data subjects need not demonstrate harm in order to establish violations of data privacy.

The second form of privacy recognized by $E U$ law is dignitary privacy. Article 7 of the Charter of Fundamental Rights of the European Union protects the dignity of persons by regulating inappropriate communications that threaten to degrade, humiliate, or mortify them. Dignitary privacy follows a normative logic designed to prevent harm to personality caused by the violation of civility rules. There are the same privacy values as those safeguarded by the American tort of public disclosure of private facts. Throughout the world, courts protect dignitary privacy by balancing the harm that a communication may cause to personality against legitimate public interests in the communication.

The instrumental logic of data privacy is inapplicable to public discourse, which is why the Directive contains derogations for journalistic activities. The communicative action characteristic of the public sphere is made up of intersubjective dialogue, which is antithetical both to the instrumental rationality of data privacy and to its aspiration to ensure individual control of personal information. Because the Google search engine underwrites the public sphere in which public discourse takes place, Google Spain should not have applied fair information practices to Google searches. But the Google Spain opinion also invokes Article 7, and in the end the decision creates doctrinal rules that are roughly approximate to those used to protect dignitary privacy. The Google Spain opinion is thus deeply confused about the kind of privacy it wishes to protect. It is impossible to ascertain whether the decision seeks to protect data privacy or dignitary privacy.

Google Spain is ultimately pushed in the direction of dignitary privacy because data privacy is incompatible with public discourse, whereas dignitary privacy may be reconciled with the requirements of public discourse. Insofar as freedom of expression is valued because it fosters democratic self-government, public discourse cannot serve as an effective instrument of self-determination without a modicum of civility. Yet the Google Spain decision recognizes dignitary privacy only in a rudimentary and unsatisfactory way. If it had more clearly focused on the requirements of dignitary privacy, Google Spain would not so sharply have distinguished Google links from the underlying 
websites to which they refer. Google Spain would not have blithely outsourced the enforcement of the right to be forgotten to a private corporation like Google.

\section{TABLE OF CONTENTS}

Introduction

I. A Critical Analysis of Google Spain

A. Data Privacy and Ordinary Life ....

B. Data Privacy, Dignitary Privacy, and the Public Sphere

C. Ambiguities in the Google Spain Opinion ......................1010

II. The Rise of a "Newspaperized World" ........................................1017

III. Google and the Public Sphere..................................................1039

IV. Google, the RTBF, and the Right To Be Forgotten .................1046

A. Google and the RTBF ..................................................1047

B. Google Spain and the Right To Be Forgotten.................1054

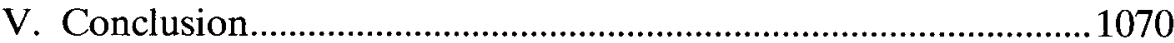

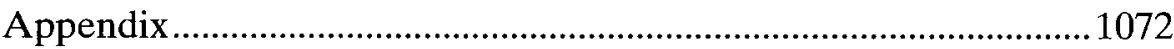

\section{INTRODUCTION}

Lying at the intersection of big data and mass communication, the Internet has become the site of furious tension between data privacy and freedom of expression. The conflict is especially acute in the European Union (EU), which highly prizes the protection of personal information.

Data privacy is typically secured by "fair information practices" that seek to ensure the accuracy, transparency, and instrumental rationality of data processing. ${ }^{1}$ Article 40 of the 1978 French Privacy

1. David H. Flaherty, Governmental Surveillance and Bureaucratic Accountability: Data Protection Agencies in Western Societies, 11 SCI. TECH. \& HuM. VAluEs 7, 8 (1986). "The West German state of Hesse passed the first general data protection law in 1970," followed by "Sweden (1973); United States (1974); Federal Republic of Germany (1977); Canada (1977); France (1978); and the United Kingdom (1984)." Id. at 7-8. "The influential [1981] OECD Guidelines on the Protection of Privacy and Transborder Flows of Personal Data summarize the basic principles for national application in the following terms: collection limitation, data quality, purpose specification, use limitation, security safeguards, openness, individual participation, and accountability." Id. at 8 . 
Law $^{2}$ established "the central principle of the right to be forgotten,"3 providing that "[e]very data subject can ... require the data controller to rectify, complete, update, lock out or erase personal data relating to him or her, where the data is inaccurate, incomplete, ambiguous, expired, or whose collection, use, communication or storage is forbidden." ${ }^{4}$

Fair information practices were consolidated in the EU in 1995 with the adoption of Directive 95/46/EC (Directive), which "is probably the most influential data privacy text in the world." The Directive requires Member States to protect the privacy of "data subjects" by enacting laws that require personal data be "collected [only] for specified, explicit and legitimate purposes and not further processed in a way incompatible with those purposes"; that the processing of data be "adequate, relevant and not excessive in relation to the purposes for which they are collected"; that personal data be maintained accurately and "kept up to date"; and that personal data be "kept in a form which permits identification of data subjects for no longer than is necessary for the purposes for which the data were

2. Loi No. 78-17 du 6 janvier 1978 relative à l'informatique, aux fichiers et aux libertés [Law 78-17 of January 6, 1978 on Information Technology, Data Files and Civil Liberties], JOURNAL OFFICIEL DE LA REPUBLIQUE FRANÇAISE [J.O.] [OFFICIAL GAZETTE OF FRANCE], Jan. 7, 1978, art. 40 .

3. David H. Flaherty, Protecting Privacy in Surveillance Societies: The FEDERAL REPUBlic OF GERMANY, SWEDEN, FRANCE, CANADA, AND THE UNITED STATES 180 (1989). Writing in 1989, Flaherty praised the right to be forgotten as of "inestimable importance for data protection in every country." Id . at 210 . He listed "[ $\mathrm{t}]$ he right to be forgotten, including the ultimate anonymization or destruction of almost all personal information," in his table of "Data Protection Principles and Practices for Government Personal Information Systems." Id. at 380 tbl.7.

4. Loi No. 78-17 du 6 janvier 1978 relative à l'informatique, aux fichiers et aux libertés [Law 78-17 of January 6, 1978 on Information Technology, Data Files and Civil Liberties], JOURNAL OFFICIEL DE LA REPUBLIQUE FRANÇAiSE [J.O.] [OFFICIAL GAZETTE OF FRANCE], Jan. 7, 1978, art. 40. "The Computer, which has a power and memory so superior to man, must be made to forget." FRENCH NAT'L COMM'N ON INFORMATICS \& FREEDOMS, REPORT 98 (1981).

5. Directive 95/46/EC of the European Parliament and of the Council of 24 October 1995 on the Protection of Individuals with Regard to the Processing of Personal Data and on the Free Movement of such Data, 1995 O.J. (L 281) 31 (EC) [hereinafter Directive]. The Directive was designed to implement the Council of Europe Data Protection Convention of 1981. Convention for the Protection of Individuals with Regard to Automatic Processing of Personal Data, Jan. 1, 1981, E.T.S. No. 108.

6. Stefan Kulk \& Frederik Zuiderveen Borgesius, Privacy, Freedom of Expression, and the Right To Be Forgotten in Europe, in CAMBRIdGE HANDBOOK OF CONSUMER PRIVACY (Jules Polonetsky, Omer Tene \& Evan Selinger eds., forthcoming 2018) (manuscript at 14), https:// papers.ssrn.com/sol3/papers.cfm?abstract_id=2652171 [https://perma.cc/T72H-EVG5]. 
collected." The Directive provides that data subjects can rectify, erase, or block the use of data processed in ways that violate its requirements. ${ }^{8}$

A decade after the promulgation of the Directive, the EU entrenched its commitment to data privacy by ratifying Article 8 of the Charter of Fundamental Rights of the European Union (Charter), ${ }^{9}$ which came into effect with the 2009 Treaty of Lisbon. ${ }^{10}$ Article 8 is entitled "Protection of Personal Data," and it provides that:

1. Everyone has the right to the protection of personal data concerning him or her.

2. Such data must be processed fairly for specified purposes and on the basis of the consent of the person concerned or some other legitimate basis laid down by law. Everyone has the right of access to data which has been collected concerning him or her, and the right to have it rectified.

3. Compliance with these rules shall be subject to control by an independent authority. ${ }^{11}$

Article 8 codifies the essence of fair information practices and in effect mandates that they be enforced by independent data protection agencies.

Although there was always a potential contradiction between data privacy and freedom of expression, that tension remained largely latent until it burst into public view in 2014 when the Court of Justice of the European Union (CJEU) decided the monumental case of Google

7. Directive, supra note 5, art. 6(1).

8. Id. art. 12(b).

9. Charter of Fundamental Rights of the European Union art. 8, December 7, 2000, 2000 O.J. (C 364) 1, 10 [hereinafter Charter].

10. See Treaty of Lisbon Amending the Treaty on European Union and the Treaty Establishing European Community, Dec. 13 2007, 2007 O.J. (C 306) 1 [hereinafter Treaty of Lisbon]. The Consolidated Version of the Treaty on the Functioning of the European Union, 2012 O.J. (C 326) 47 reiterates:

1. Everyone has the right to the protection of personal data concerning them.

2. The European Parliament and the Council, acting in accordance with the ordinary legislative procedure, shall lay down the rules relating to the protection of individuals with regard to the processing of personal data by Union institutions, bodies, offices and agencies, and by the Member States when carrying out activities which fall within the scope of Union law, and the rules relating to the free movement of such data. Compliance with these rules shall be subject to the control of independent authorities. Id. at 55 .

11. Charter, supra note 9 , art. 8. 
Spain SL v. Agencia Española de Protección de Datos. ${ }^{12}$ The CJEU held that the Directive, as well as Articles $7^{13}$ and 8 of the Charter, authorize a "data subject" to require the operator of a search engine "to remove from the list of results displayed following a search made on the basis of his name" links to web pages published lawfully by third parties and containing true information relating to him, "on the ground that ... he wishes it to be 'forgotten' after a certain time."14

Google Spain did not focus on the processing of personal data collected by the Google search engine (Google) from its own customers. ${ }^{15}$ It instead applied the right to be forgotten to constrain Google's public communication of public information. Insofar as Google Spain relied on Article 8 and the Directive, the decision vastly expanded the reach of fair information practices. This expansion was reaffirmed in April 2016 when the EU promulgated the General Data Protection Regulation (GDPR) ${ }_{1}^{16}$ which will become the law of all EU member states on May 25, 2018. ${ }^{17}$ The GDPR replaces the Directive

12. Case C-131/12, Google Spain SL v. Agencia Española de Protección de Datos, 2014 E.C.R. 317 [hereinafter Google Spain]. For a discussion of previous tension between data protection laws and new digital media, see David Erdos, Data Protection Confronts Freedom of Expression on the "New Media" Internet: The Stance of European Regulatory Authorities, 40 EUR. L. REV. 531 (2015).

13. Article 7 is entitled "Respect for private and family life," and it provides that "[e]veryone has the right to respect for his or her private and family life, home and communications." Charter, supra note 9 , art. 7 .

14. Google Spain, supra note 12, para. 89; see id. at para. 99. In January 2012, the European Commission had proposed to the European Parliament fair information practices that included a "Right to be forgotten and to erasure," essentially based upon the French right to be forgotten described in supra note 2 and accompanying text. See Proposal for a Regulation of the European Parliament and of the Council on the Protection of Individuals with Regard to the Processing of Personal Data and on the Free Movement of Such Data (General Data Protection Regulation), art. 17, COM (2012) 11 final (Jan. 25, 2012) [hereinafter Proposed GDPR].

15. On Google's collection of data about its customers, see Elisabeth A. Jones \& Joseph W. Janes, Anonymity in a World of Digital Books: Google Books, Privacy, and the Freedom To Read, 2 POL. \& INTERNET 43 (2010) and Bart van der Sloot \& Frederik J. Zuiderveen Borgesius, Google and Personal Data Protection, in GOOGLE AND THE LAW: EMPIRICAL APPROACHES TO LEGAL ASPECTS OF KNOWLEDGE-ECONOMY BuSINESS MODELS 75 (Aurelio Lopez-Tarruella ed., 2012). On the application of the Directive to Google's gathering of "user data," see ARTICLE 29 DATA Prot. WORKING PARTY, OPINION 1/2008 ON DATA PROTECTION ISSUES Related TO SEARCH ENGINES (2008), http:/ec.europa.eu/justice/data-protection/article-29/documentation/ opinion-recommendation/files/2008/wp148_en.pdf [https:/perma.cc/C23U-B9WB].

16. A version of the right to be forgotten had already been included in previous drafts of the GDPR. See Proposed GDPR, supra note 14, art. 17.

17. Regulation (EU) 2016/679 of the European Parliament and of the Council of 27 April 2016 on the Protection of Natural Persons with Regard to the Processing of Personal Data and on the Free Movement of Such Data, and Repealing Directive 95/46/EC (General Data Protection Regulation), 2016 O.J. (L 119) 1, 43-45, 87 [hereinafter GDPR]. 
and contains a right to be forgotten that will likely be interpreted in light of Google Spain. ${ }^{18}$ The GDPR marks the triumph of a distinctive EU variant of the right to be forgotten that derives directly from data privacy and that can be expected to have massive international consequences. ${ }^{19}$ It sharply poses the general theoretical question of how fair information practices can be reconciled with freedom of expression. $^{20}$

18. Article $\mathbf{1 7}$ of the GDPR, which is entitled "Right to erasure ('right to be forgotten')," is an explicit gesture toward the holding of Google Spain. It provides:

1. The data subject shall have the right to obtain from the controller the erasure of personal data concerning him or her without undue delay and the controller shall have the obligation to erase personal data without undue delay where one of the following grounds applies:

(a) the personal data are no longer necessary in relation to the purposes for which they were collected or otherwise processed;

(b) the data subject withdraws consent on which the processing is based according to point (a) of Article 6(1), or point (a) of Article 9(2), and where there is no other legal ground for the processing;

(c) the data subject objects to the processing pursuant to Article 21(1) and there are no overriding legitimate grounds for the processing, or the data subject objects to the processing pursuant to Article 21(2);

(d) the personal data have been unlawfully processed;

(e) the personal data have to be erased for compliance with a legal obligation in

Union or Member State law to which the controller is subject;

(f) the personal data have been collected in relation to the offer of information society services referred to in Article 8(1).

2. Where the controller has made the personal data public and is obliged pursuant to paragraph 1 to erase the personal data, the controller, taking account of available technology and the cost of implementation, shall take reasonable steps, including technical measures, to inform controllers which are processing the personal data that the data subject has requested the erasure by such controllers of any links to, or copy or replication of, those personal data.

3. Paragraphs 1 and 2 shall not apply to the extent that processing is necessary:

(a) for exercising the right of freedom of expression and information;

(b) for compliance with a legal obligation which requires processing by Union or Member State law to which the controller is subject or for the performance of a task carried out in the public interest or in the exercise of official authority vested in the controller;

(c) for reasons of public interest in the area of public health in accordance with points (h) and (i) of Article 9(2) as well as Article 9(3);

(d) for archiving purposes in the public interest, scientific or historical research purposes or statistical purposes in accordance with Article 89(1) in so far as the right referred to in paragraph 1 is likely to render impossible or seriously impair the achievement of the objectives of that processing; or

(e) for the establishment, exercise or defence of legal claims.

Id. art. 17.

19. On the international consequences of European data privacy regulations, see Communication from the Commission to the European Parliament and the Council: Exchanging and Protecting Personal Data in a Globalised World, COM (2017) 7 final (Jan. 10, 2017).

20. Google Spain strongly suggests that the GDPR will be interpreted to control the use of Internet search engines. See Recent Case, C-131/12, Google Spain SL v. Agencia Española de Protección de Datos (May 13, 2014), 128 HARV. L. ReV. 735, 742 (2014). 
Google Spain's extension of fair information practices to Internet search engines has been intensely controversial. ${ }^{21}$ Since June 2014, Google Spain has prompted Google to process at least 703,910 requests to remove $1,948,737$ URLs from its search engine, and to erase from searches made under the name of the person requesting removal at least 43.2 percent of those URLs. ${ }^{22}$ In the past several years, the right to be forgotten has been asserted by a vicar who resigned after villagers accused him of standing naked at a vicarage window and swearing at children; by a doctor convicted of attempting to spike his pregnant mistress' drinks with drugs to cause a miscarriage of their son; and by a butcher convicted of blackmail for threatening to send his estranged wife's wealthy parents videos of her participating in group sex. ${ }^{23}$ The right to be forgotten has even been asserted against articles about the right to be forgotten. ${ }^{24}$

21. Steptoe Cyberlaw Podcast - Interview with David Hoffman, STEPTOE CYBERLOG (Sept. 3, 2014), at 00:34:39, http://www.steptoe.com/staticfiles/SteptoeCyberlawPodcast-032.mp3 [https://perma.cc/U3A9-F99H] (providing a breakdown of Google Spain with one commentator calling it "clinically insane"); see also Michael Wolff, Wolff: The Right To Be Forgotten by Google, USA TODAY (May 18, 2014, 7:00 PM), http:/www.usatoday.com/story/moncy/columnist/wolff/ 2014/05/18/a-big-setback-for-google-in-europe/9172941 [https://perma.cc/8DJT-XXRJ] ("The world reaction, or at least the reaction among the technologically elite and ambitious, is that this is merely a spasm from European Luddites and protectionists.").

22. Google used to provide a detailed report describing its efforts to comply with EU data protection law. See Search Removals Under European Privacy Law, GoOGLE, https:// www.google.com/transparencyreport/removals/europeprivacy/?hl=en [https:/perma.cc/D5E7GEVT ] (last updated Sept. 28, 2017).

23. Rhiannon Williams, Telegraph Stories Affected by EU 'Right to be Forgotten,' TEleGraPH (Sept. 3, 2015, 9:52 AM), http:/www.telegraph.co.uk/technology/google/11036257/ Telegraph-stories-affected-by-EU-right-to-be-forgotten.html [https://perma.cc/J2NM-RCWN]; see James Ball, EU's Right To Be Forgotten: Guardian Articles Have Been Hidden by Google, GUARDIAN (July 2, 2014), https:/www.theguardian.com/commentisfree/2014/jul/02/eu-right-tobe-forgotten-guardian-google [https://perma.cc/UQ4N-ZRL5]; Caitlin Dewey, Pianist Asks The Washington Post To Remove a Concert Review Under the E.U.'s "Right To Be Forgotten" Ruling, WASH. POST (Oct. 31, 2014), https:/www.washingtonpost.com/news/the-intersect/wp/2014/10/31/ pianist-asks-the-washington-post-to-remove-a-concert-review-under-the-e-u-s-right-to-be-forgot ten-ruling/ [https://perma.cc/Z5H3-XUZM].

24. The right was asserted by the plaintiff in the Google Spain decision to suppress links to comments about the opinion. Miquel Peguera, No More Right-to-be-Forgotten for Mr. Costeja, Says Spanish Data Protection Authority, CTR. FOR INTERNET \& SOC'Y (Oct. 3, 2015, 8:24 AM), http://cyberlaw.stanford.edu/blog/2015/10/no-more-right-be-forgotten-mr-costeja-says-spanishdata-protection-authority [https://perma.cc/M2ZC-VD7J]; see also Mike Masnick, Google Disappears Techdirt Article About Right To Be Forgotten Due to Right To Be Forgotten Request, TECHDIRT (Aug. 25, 2015, 8:35 AM), https://www.techdirt.com/articles/20150824/13495432050/ google-disappears-techdirt-article-about-right-to-be-forgotten-due-to-right-to-be-forgottenrequest.shtml [https://perma.cc/4P56-5SDS] (describing how shortly after posting an article about Google "being asked to 'forget' articles," Techdirt was itself notified that the same article "has been similarly stuffed down the memory hole."). 
The Index on Censorship denounced Google Spain as "akin to marching into a library and forcing it to pulp books." ${ }^{25}$ The European Union Committee of the British House of Lords responded to Google Spain by concluding (in bold-faced type) that "the 'right to be forgotten' ... must go. It is misguided in principle and unworkable in practice." ${ }^{26}$ Jimmy Wales, the cofounder of Wikipedia, condemned the right to be forgotten as "deeply immoral" because "[h]istory is a human right." ${ }^{27}$ The American legal scholar Jeffrey Rosen has observed that Google Spain and the GDPR portend a "titanic clash" with American free speech principles. ${ }^{28}$

25. Index Blasts EU Court Ruling on "Right to be Forgotten," INDEX (May 13, 2014), https:/www.indexoncensorship.org/2014/05/index-blasts-eu-court-ruling-right-forgotten [https:// perma.cc/Y4EG-YW9W].

26. European Union Comm., 2D Report, EU Data Protection LAw: A 'Right To Be FORGOTTEN'?, 2014-15, HL-40, 62 (UK).

27. Sophie Curtis \& Alice Philipson, Wikipedia Founder: EU's Right To Be Forgotten Is 'Deeply Immoral,' TELEGRAPH (Aug. 6, 2014, 12:07 PM), http:/www.telegraph.co.uk/technology/ wikipedia/11015901/EU-ruling-on-link-removal-deeply-immoral-says-Wikipedia-founder.html [https://perma.cc/7VMU-KAWJ].

28. Jeffrey Rosen, The Right To Be Forgotten, ATLANTIC (July/Aug. 2012), hitp:// www.theatlantic.com/magazine/archive/2012/07/the-right-to-be-forgotten/309044/ [https://perma. cc/RV4F-8WVC]. The clash with First Amendment values is especially stark in light of the decision of the French Data Protection Agency, the Commision Nationale de l'Informatique et des Libertés ("CNIL"), that the right to be forgotten requires Google universally to delist links in every domain served by Google, and not, as is presently the case, merely in domains governed by EU law. Compare Search Removals Under European Privacy Law, supra note 22 ("We delist URLs from all European Google Search domains (google.fr, google.de, google.es, etc.)."), and Samuel Gibbs, Google To Extend 'Right to be Forgotten' to All Its Domains Accessed in EU, GUARDIAN (Feb. 11 2016), https://www.theguardian.com/technology/2016/feb/11/google-extendright-to-be-forgotten-googlecom [https://perma.cc/92LQ-3LZQ] ("If a German resident successfully requests Google remove a search result under queries for their name, the link will not be visible on any version of Google's website, including Google.com, when the search engine is accessed from Germany. Google will use the browser's IP address to determine their location."), with Press Release, Commision Nationale de l'Informatique et des Libertés, CNIL Orders Google To Apply Delisting on All Domain Names of the Search Engine (June 12, 2015), https://www.cnil.fr/fr/node/15790 [https://perma.cc/F8GR-W3P9] ("Although the company has granted some of the requests, delisting was only carried out on European extensions of the search engine and not when searches are made from 'google.com' or other non-European extensions."). Google appealed the CNIL decision to the highest French administrative court, the Conseil d'Etat, see Alex Hern, Google Takes Right To Be Forgotten Battle to France's Highest Court, GUARDIAN (May 19, 2016), https:/www.theguardian.com/technology/2016/may/19/google-rightto-be-forgotten-fight-france-highest-court [https://perma.cc/P6G3-8RS9], which has in turn referred the question to the CJEU. See Alex Hern, ECJ To Rule on Whether 'Right To Be Forgotten' Can Stretch Beyond EU, GUARDIAN (July 20, 2017), https:/www.theguardian.com/ technology/2017/jul/20/ecj-ruling-google-right-to-be-forgotten-beyond-eu-france-data-removed [https://perma.cc/E7DU-E7XC]. For a recent world-wide injunction against Google affirmed by the Canadian Supreme Court, see Google Inc. v. Equustek Sols. Inc., 2017 S.C.C. 34 (Can.).

The right to be forgotten has already spread to Argentina, Edward L. Carter, Argentina's 
In this Article, I shall not seek to resolve this epic clash. I shall instead defend two limited claims about the application of the right to be forgotten to Internet search engines. First, I shall argue that critics of Google Spain are correct to be alarmed about the conceptual architecture of the decision, because the CJEU misunderstands the relationship between Google and the construction of the contemporary public sphere. Google Spain dismisses Google as a mere profit-making, data-processing corporation. But that interpretation of Google fails to appreciate how Internet search engines underwrite the virtual communicative space in which democratic public opinion is now partially formed. Google should have been accorded the same legal status as print media. I support this assertion by offering a brief history of how newspapers created the modern democratic public sphere in the United States in the nineteenth and twentieth centuries.

Second, I shall claim that Google Spain misunderstands the nature of the privacy rights that should apply to the public sphere. Insofar as it is engaged in public communication, the press ought not to be constrained by data privacy. Instead it may be controlled by the kind of privacy protected in Article 7 of the Charter, which provides that "[e]veryone has the right to respect for his or her private and family life, home and communications." ${ }^{29}$ The text of Article 7 of the Charter essentially reproduces Article 8 of the European Convention for the Protection of Human Rights and Fundamental Freedoms (European Convention) ${ }^{30}$ which indicates that it is meant to be interpreted in the same way that the European Court of Human Rights (ECtHR) interprets Article 8 of the European Convention. ${ }^{31}$

Right to be Forgotten, 27 EMORY INT'L L. REV. 23 (2013); Robert Krulwich, Is the 'Right To Be Forgotten' The 'Biggest Threat To Free Speech On the Internet'?, NPR: KRULWICH WONDERS (Feb. 24, 2012, 9:06 AM), http:/www.npr.org/sections/krulwich/2012/02/23/147289169/is-theright-to-be-forgotten-the-biggest-threat-to-free-speech-on-the-internet [https:/perma.cc/3TY63MSW], and Colombia, Colombia: Constitutional Court Rules on the "Right to be Forgotten," INT'L ACAD. OF COMP. L. (July 14, 2015), http://iuscomparatum.info/colombia-constitutionalcourt-rules-on-the-right-to-be-forgotten/ [https://perma.cc/87KL-FAJF]. Japan seems to have resisted the trend. Jon Russell, Google Wins 'Right to be Forgotten' Battle in Japan, TECHCRUNCH (Feb. 1, 2017), https://techcrunch.com/2017/02/01/google-japan-negative-comments/ [https:// perma.cc/3BSZ-PE6E]. On the potential influence of the right in Asia, see Steven C. Bennett, $I s$ America Ready for the Right to Be Forgotten?, 88 N.Y. STATE BAR J. 10, 12 (2016).

29. Charter, supra note 9 , art. 7.

30. Article 8 of the European Convention provides: "Everyone has the right to respect for his private and family life, his home and his correspondence." European Convention for the Protection of Human Rights and Fundamental Freedoms, Nov. 4, 1950, 213 U.N.T.S. 221, 230.

31. Article 52(3) of the Charter provides that "[i]n so far as this Charter contains rights which correspond to rights guaranteed by the Convention for the Protection of Human Rights and 
Although the ECtHR has sometimes interpreted Article 8 of the European Convention to require fair information practices, ${ }^{32}$ it has more frequently interpreted Article 8 to proscribe the communication of "personal information which individuals can legitimately expect should not be published without their consent"33 because it would damage their "honour" or "psychological or moral integrity" 34 or "prejudice" their "personal enjoyment of the right to respect for private life." ${ }^{35}$ It has sought to balance the "seriousness" of harms caused by publications against their "contribution ... to a debate of general interest." 36 Article 7 of the Charter protects what we may call "dignitary privacy." 37

The dignitary privacy rights created by Article 7 of the Charter differ in important ways from the data privacy rights of Article 8 of the Charter. If the latter define and enforce the proper bureaucratic

Fundamental Freedoms, the meaning and scope of those rights shall be the same as those laid down by the said Convention." Charter, supra note 9 , art. 52.

32. See, e.g., S. \& Marper v. United Kingdom, 2008-V Eur. Ct. H.R. 167, 202 (holding that Article 8 required that with respect to personal data acquired through government surveillance there must be "clear, detailed rules governing the scope and application of measures, as well as minimum safeguards concerning, inter alia, duration, storage, usage, access of third parties, procedures for preserving the integrity and confidentiality of data and procedures for its destructions, thus providing sufficient guarantees against the risk of abuse and arbitrariness"). In contrast to the Charter, the European Convention does not contain any specific right to the protection of data privacy.

33. Axel Springer AG v. Germany, App. No. 39954/08, para. 83 (Eur. Ct. H.R. Feb. 7, 2012), http://hudoc.echr.coe.int/eng?i=001-109034 [https://perma.cc/64JM-LPNC].

34. A v. Norway, App. No. 28070/06, para 63 (Eur. Ct. H.R. Apr. 9, 2009), https:// lovdata.no/static/EMDN/emd-2011-024130.pdf [https://perma.cc/P5LM-497P].

35. Axel Springer AG v. Germany, App. No. 39954/08, para. 83 (Eur. Ct. H.R. Feb. 7, 2012), http://hudoc.echr.coe.int/eng?i=001-109034 [https://perma.cc/64JM-LPNC].

36. Id. para. 83, 89, 90. This is essentially how an American court might recognize the right to prevent the public disclosure of private facts. For example, the Restatement (Second) of Torts provides:

One who gives publicity to a matter concerning the private life of another is subject to liability to the other for invasion of his privacy, if the matter publicized is of a kind that

(a) would be highly offensive to a reasonable person, and

(b) is not of legitimate concern to the public.

RESTATEMENT (SECOND) OF TORTS § 652D (AM. LAW INST. 1977).

37. Robert Kirk Walker, Note, The Right To Be Forgotten, 64 HAstings L.J. 257, 270 (2012) ("European privacy laws are primarily intended to safeguard an individual's dignity and public image, rather than to protect against governmental intrusions. This attitude is reflected in Article

- 8 of the European Convention of Human Rights, which .... draws its inspiration from the French tradition of protecting citizens' reputations against compromising intrusions by others, particularly the media. Because of this tradition, European courts tend to be less preoccupied with protecting free speech rights from government interference than American courts, and more willing to restrict speech if necessary to protect the dignitary rights of citizens." (footnotes omitted)). 
handling of data, the former define and enforce social norms of respectful expression. Although these distinct rights require discrete forms of legal analysis, a version of "the right to be forgotten" exists within both rights - the right to be forgotten can refer either to the need to erase data that are no longer necessary to retain, ${ }^{38}$ or to the need to regulate communications that disrespectfully dredge up old events which compromise the dignity of a person..$^{39}$ In the law of many European countries,${ }^{40}$ the latter version of the right to be forgotten is known as "le Droit à l'Oubli," which places "a time limit on the publication of information: the press ... cannot continue to publicize matters that are no longer in the public interest" and that can "relentlessly harm" persons "beyond a period of newsworthy relevancy." ${ }^{41}$ This is the form of the right to be forgotten that the

38. See supra notes $3-4$.

39. See, e.g., Briscoe v. Reader's Digest Ass'n, 483 P.2d 34, 37 (Cal. 1971), overruled by Gates v. Discovery Commc'ns, Inc., 101 P.3d 552 (Cal. 2004); Melvin v. Reid, 297 P. 91, 93 (Cal. App. 1931); Franz Werro, The Right To Inform v. The Right To Be Forgotten: A Transatlantic Clash, in HAFTUNGSRECHT IM DRITTEN MILLENNIUM: LIABILITY IN THE THIRD MILLENNIUM 285, 28586 (Aurelia Colombi Ciacchi et al. eds., 2009); Steven C. Bennett, The "Right to Be Forgotten": Reconciling EU and US Perspectives, 30 BERKELEY J. INT'L L. 161, 169-72 (2012); Ashley Messenger, What Would a "Right to Be Forgotten" Mean for Media in the United States?, CoMM. LAW., June 2012, at 29, 29-30, 32-33.

40. Alessandro Mantelero, The EU Proposal for a General Data Protection Regulation and the Roots of the 'Right To Be Forgotten', 29 COMPUTER L. \& SECURITY REV. 229, 229 (2013).

41. Steven M. LoCascio, Forcing Europe to Wear Rose-Colored Google Glass: The "Right to be Forgotten" and the Struggle To Manage Compliance Post Google Spain, 54 Colum. J, TRANSNAT'L L. 296, 300 (2015). Professor Rolf Weber has written:

In Continental Europe, the right to be forgotten can be considered as being contained in the right of the personality, encompassing several elements such as dignity, honor, and the right to private life. Manilold terminologies are used in the context of the right of personality-mainly the right for the (moral and legal) integrity of a person not to be infringed and for a sphere of privacy to be maintained and distinguished.

Rolf H. Weber, The Right To Be Forgotten: More Than a Pandora's Box?, 2 J. INTELL. PRoP. INFO. TECH. \& ELECTRONIC COM. L. 120, 121 (2011), https://www.jipitec.eu/issues/jipitec-2-22011/3084/jipitec $\% 202 \% 20-\% 20 \mathrm{a} \% 20$ - \%20weber.pdf [https://perma.cc/S2HD-DJJR]; see also Jeffrey Rosen, The Right to Be Forgotten, 64 STAN. L. REv. ONLINE 88 (2012), https://review.law.stanford .edu/wp-content/uploads/sites/3/2012/02/64-SLRO-88.pdf [https:// perma.cc/M3BA-4MDU]. This form of the right to be forgotten is quite relevant to Spanish privacy law, which explicitly draws on cases like Melvin v. Reid, 297 P. 91 (Cal. App. 1931). See XAVIER O'CALLAGHAN MUNOZ, LIBERTAD DE EXPRESION Y SUS LIMITES: HONOR E IMAGEN 54-55 (1991); PABLO SALVADOR CODERCH, ¿QUE ES DIFAMAR? LIBELO CONTRA LA LEY DEL LIBELO 97-98 (1987); Patricia Sánchez Abril \& Jacqueline D. Lipton, The Right To Be Forgotten: Who Decides What the World Forgets, 103 KY. L.J. 363, 367-68 (2014). Section 18 (1) of the 1978 Spanish Constitution protects "The right to honour, to personal and family privacy and to the own image is guaranteed," and Section 18(4) provides that "The law shall restrict the use of data processing in order to guarantee the honour and personal and family privacy of citizens and the full exercise of their rights." C.E., B.O.E. art. 18, Mar. 16, 2016. For French cases, see Tribunal de Grande Instance [TGI] [ordinary court of original jurisdiction] Paris, Mar. 25, 1987, D. Somm, 
ECtHR has read into Article 8 of the European Convention and hence that exists in Article 7 of the Charter. ${ }^{42}$

In this Article, I use "RTBF" to refer to the distinct bureaucratic version of the right to be forgotten created by the Directive to protect data privacy, and I use "right to be forgotten" to refer to the more traditional version of the right that protects dignitary privacy and that is rooted in Article 7 of the Charter and in the tort law of many nations..$^{43}$ Google Spain seeks to support its judgment by invoking both Article 8 and Article 7 of the Charter ${ }^{44}$ It therefore appeals both to the RTBF and to the right to be forgotten. Yet these two rights are based upon distinct and antagonistic assumptions about the nature of social life.

The RTBF imagines a bureaucratic world that conforms to an instrumental logic in which data are gathered and used for "specified purposes." ${ }^{45}$ The right to be forgotten, by contrast, presupposes a world of public communications governed by norms of propriety in which information is the medium of an intersubjective dialogue unconstrained by antecedent specified purposes and free to follow an ongoing play of ideas and interests. The RTBF applies to data management; the right to be forgotten applies to communication. The object of the RTBF is to give data subjects "control" over their

198 ("[A]ny person associated with a public event, even if that person were the perpetrator, can claim a right to disallow the memory and to oppose any reminder of that event."); Cour d'Appel de Versailles, 14 septembre 1989, Jamet, Tesson et autres c/ consorts Girard: Gazette du Palais, $1990, n^{\circ} 1, p .123$ ("[T]he passage of a sufficiently long time [between deeds and their becoming public again] can, for the person who has been the perpetrator, render these deeds private, relegated to secrecy and oblivion."); Cour D'appel de Montpellier, 8 avr. 1997 ("[I]f no right to oblivion can be recognized absolutely, it is the judge's responsibility to decide in function of the circumstances of the case, bearing in mind, certainly, the right of a newspaper to bring forth free, complete, and objective information to its readership, but also bearing in mind the relative seriousness of the deeds and the time that has elapsed since their having been committed as well as the efforts at rehabilitation of those convicted in the past. As soon as they have paid the penalty, they can legitimately seek to repress the memory of the deeds."). Each quotation above was translated from the original French by Professors R. Howard Bloch and Patrick Weil.

42. Catherine Bratic, Note, A Comparative Approach to Understanding Developments in Privacy Rights in the European Court of Human Rights, 19 Colum. J. EuR. L. 341, 347 (2013).

43. On the contrast between the two forms of rights, see MEG LETA JONES, CTRL $+Z$ : THE Right TO BE ForgotTen 96 (2016) and Aurelia Tamò \& Damian George, Oblivion, Erasure and Forgetting in the Digital Age, 5 J. INTELL. Prop. INFO. TECH. \& ElECTRONIC COM. L. 71 (2014), https://www.jipitec.eu/issues/jipitec-5-2-2014/3997/oblivion \%2C\%20erasure \%20and \%20 forgetting $\% 20 \mathrm{in} \% 20$ the \%20digital \%20age.pdf [https://perma.cc/3QPS-AG2X].

44. See Google Spain, supra note 12, para. 69.

45. Charter, supra note 9 , art. 8 (emphasis added). 
personal data ${ }^{46}$ the object of the right to be forgotten is to protect the dignity of human beings. ${ }^{47}$ Although the RTBF makes sense in the context of large organizations that assemble big data to accomplish explicit purposes, its managerial logic is fundamentally incompatible with the communicative action required by the democratic public sphere. ${ }^{48}$ The right to be forgotten, by contrast, has been applied to the democratic public sphere in most legal systems for more than a century.

There is no doubt serious tension between the right to be forgotten and freedom of expression, and different legal systems resolve this tension in different ways. ${ }^{49} \mathrm{I}$ do not advocate for any single resolution of this conflict. Instead the second claim in this Article is that Google Spain blurs the instrumental reason of the RTBF with the normative logic of the right to be forgotten in ways that are conceptually confused and legally undesirable. Google Spain is ultimately an ambiguous and opaque decision because it is uncertain whether the CJEU sought to preserve the right of data subjects to control personal information or instead to safeguard the dignity of human beings. We do not know whether the object of the decision is data privacy or dignitary privacy.

46. "Generally, the 'privacy-as-control' approach has manifested in the area of personal information protection as a call for awarding individuals the greatest control possible over their personal information. This is reflected in what are commonly referred to as Fair Information Practices." Avner Levin \& Patricia Sánchez Abril, Two Notions of Privacy Online, 11 VAND.J. ENT. \& TECH. L. 1001, 1009 (2009); see also JONES, supra note 43, at 94 ("The right to be forgotten represents 'informational self-determination' as well as the control-based definition of privacy and attempts to migrate personal information from a public sphere to a private sphere." (footnote omitted) (citing VikTOR MAYER-SCHÖNBERGER, DELETE: THE VIRTUE OF FORGETTING IN THE DIGITAL AGE 126(2011))). This is also the popular understanding of data privacy. Reporting the results of the Google Spain decision, The Guardian proclaimed: "Individuals have right to control their data and can ask search engines to remove results." Alan Travis \& Charles Arthur, EU Court Backs 'Right To Be Forgotten': Google Must Amend Results on Request, GUARDIAN (May 13, 2014), https:/www.theguardian.com/technology/2014/may/13/right-to-be-forgotten-eucourt-google-search-results [https://perma.cc/2ENK-WCD3]. In this regard, the right to "control" the use of existing personal data may be distinguished from the right to prevent surveillance, which consists of the right to prevent companies from augmenting their accumulation of personal data. See Neil M. Richards, The Dangers of Surveillance, 126 HARV. L. REV. 1934, 1961 (2014).

47. "Perhaps two of the most prominent conceptions of privacy are the control-based and the dignitarian." Patrick O'Callaghan, The Chance 'to Melt into the Shadows of Obscurity': Developing a Right To Be Forgotten in the United States, in PRIVACY: CORE CONCEPTS AND CONTEMPORARY ISSUES (Ann E. Cudd \& Mark C. Navin eds., forthcoming 2018) (manuscript at 2), https://papers.ssrn.com/sol3/papers.cfm?abstract_id=300925 [https://perma.cc/WTY6DDUE].

48. On the tension between managerial and logic and the public sphere, see generally Robert C. Post, Between Governance and Management: The History and Theory of the Public Forum, 34 UCLA L. REV. 1713 (1987).

49. See generally Robert C. Post, Hate Speech, in EXTREME SPEECH AND DEMOCRACY 123 (Ivan Hare \& James Weinstein eds., 2009) (discussing how different legal systems differently resolve the tension between free expression and hate speech). 
This deep confusion undermines the doctrinal force and implications of Google Spain.

At the conclusion of this Article, I argue that Google Spain should have answered the questions presented to it in a manner that focused entirely on the right to be forgotten and on the protection of dignitary privacy. I seek to clarify how Google Spain might have been written had the CJEU properly understood the doctrinal challenge that lay before it.

\section{A CRitical Analysis of Google SPaIN}

\section{A. Data Privacy and Ordinary Life}

In 2010, Mario Costeja González, a Spanish lawyer, filed a complaint with the Agencia Española de Protección de Datos (AEPD), the Spanish Data Protection Agency. ${ }^{50}$ Twelve years before, there had been a public auction to sell property attached during proceedings against Costeja's real estate for recovery of social security debts. ${ }^{51}$ The Ministry of Labour and Social Affairs ordered a Spanish newspaper, La Vanguardia, to publish an announcement of the auction to provide "maximum publicity . . . to secure as many bidders as possible." 52 The announcement was put online in 2008 when $L a$ Vanguardia digitized its files. ${ }^{53}$ Two years later, when Costeja's name was entered into Google, the announcement turned up prominently in the results. Costeja complained that the announcement should be erased because it concerned "attachment proceedings ... [that] had been fully resolved for a number of years and that reference to them was now entirely irrelevant." 54

In response to Costeja's complaint, the AEPD held that $L a$ Vanguardia should not be required to remove its digitized files because "publication by it of the information in question was legally justified" insofar as it had been compelled by the Ministry. ${ }^{55}$ Nevertheless the AEPD concluded that the complaint against Google be upheld due to the "derecho al olvido," which is the Spanish form of the right to be

\footnotetext{
50. Google Spain, supra note 12, para. 14.

51. Id.

52. Id. para. 16.

53. Julia Powles, The Case That Won't Be Forgotten, 47 Loy. U. CHI. L.J. 583, 587 (2015).

54. Google Spain, supra note 12, para. 15.

55. Id para. 16.
} 
forgotten. ${ }^{56}$ The AEPD held that even if underlying websites like $L a$ Vanguardia remain online, search engines can nevertheless be required to take down or block access to data whenever "the fundamental right to data protection and the dignity of persons" is at risk, which could include "the mere wish of the person concerned that such data not be known to third parties." 57

Google appealed the decision to the Spanish high court, the Audiencia Nacional, which held that the resolution of the case must turn on the interpretation of the Directive. The Audiencia Nacional referred questions about the proper interpretation of the Directive to the European Court of Justice. The CJEU, interpreting the Directive in light of Articles 7 and 8 of the Charter ${ }^{58}$ held that Google should be required to delist links to La Vanguardia's announcement of the attachment proceedings from searches conducted under Costeja's name, even if La Vanguardia's web page was allowed to remain online.

The CJEU reasoned that La Vanguardia's web pages contain the "personal data" of Costeja, which the Directive defines as "any information relating to an identified or identifiable natural person ('data subject')," 59 and that Google had become a "controller" of these data by processing $L a$ Vanguardia's web pages to include them in Google's list of search results. The Directive defines a controller as an entity that determines "the purposes and means of the processing of [the] personal data." ${ }^{60}$ As a controller of data, Google must assume

the task of ensuring that personal data are processed fairly and lawfully', that they are 'collected for specified, explicit and legitimate purposes and not further processed in a way incompatible with those purposes', that they are 'adequate, relevant and not excessive in relation to the purposes for which they are collected and/or further processed', that they are 'accurate and, where necessary, kept up to

56. Id. para. 20.

57. Id. para. 17. As with Spanish law generally, see supra note 41, the decision of the AEPD unselfconsciously combines the protection of dignitary privacy with that of data privacy. Google Spain, supra note 12, para. 17. This same blending of disparate legal theories will eventually manifest itself in the CJEU Google Spain opinion.

58. The CJEU held that the provisions of the Directive "must necessarily be interpreted in the light of fundamental rights, which, according to settled case law, form an integral part of the general principles of law whose observance the Court ensures and which are now set out in the Charter." Id. para. 68; see id. para. 69.

59. Id. para. 4 (citing Directive, supra note 5, art. 2). The GDPR defines personal data in exactly the same way in Article 4(1). See GDPR, supra note 17, art. 4.

60. Google Spain, supra note 12, para. 4. The GDPR defines "controller" in exactly the same words. GDPR, supra note 17 , art. 4(7). 
date' and, finally, that they are 'kept in a form which permits identification of data subjects for no longer than is necessary for the purposes for which the data were collected or for which they are further processed'. In this context, the controller must take every reasonable step to ensure that data which do not meet the requirements of that provision are erased or rectified. ${ }^{61}$

The essential question for the CJEU was thus whether Google's processing of the data in the La Vanguardia website was "inadequate, irrelevant or no longer relevant, or excessive in relation to the purposes of the processing at issue carried out by the operator of the search engine." ${ }^{62}$ This question was determinative regardless of whether

61. Google Spain, supra note 12, para. 72. In this paragraph, the CJEU essentially restates the terms of Article 6 of the Directive. See Directive, supra note 5, art. 6. In Article 5, the GDPR defines the responsibilities of a data controller in this way:

1. Personal data shall be:

(a) processed lawfully, fairly and in a transparent manner in relation to the data subject ('lawfulness, fairness and transparency');

(b) collected for specified, explicit and legitimate purposes and not further processed in a manner that is incompatible with those purposes; further processing for archiving purposes in the public interest, scientific or historical research purposes or statistical purposes shall, in accordance with Article 89(1), not be considered to be incompatible with the initial purposes ('purpose limitation');

(c) adequate, relevant and limited to what is necessary in relation to the purposes for which they are processed ('data minimisation');

(d) accurate and, where necessary, kept up to date; every reasonable step must be taken to ensure that personal data that are inaccurate, having regard to the purposes for which they are processed, are erased or rectified without delay ('accuracy');

(e) kept in a form which permits identification of data subjects for no longer than is necessary for the purposes for which the personal data are processed; personal data may be stored for longer periods insofar as the personal data will be processed solely for archiving purposes in the public interest, scientific or historical research purposes or statistical purposes in accordance with Article 89 (1) subject to implementation of the appropriate technical and organisational measures required by this Regulation in order to safeguard the rights and freedoms of the data subject ('storage limitation');

(f) processed in a manner that ensures appropriate security of the personal data, including protection against unauthorised or unlawful processing and against accidental loss, destruction or damage, using appropriate technical or organisational measures ('integrity and confidentiality').

2. The controller shall be responsible for, and be able to demonstrate compliance with, paragraph 1 ('accountability').

GDPR, supra note 17, art. 5.

62. Google Spain, supra note 12, para. 94. The European Commission put out a fact sheet summarizing the Google Spain decision, which interprets the decision to hold that "[i]ndividuals have the right - under certain conditions - to ask search engines to remove links with personal information about them. This applies where the information is inaccurate, inadequate, irrelevant or excessive for the purposes of the data processing ...." Factsheet on the "Right to be Forgotten" Ruling (C-131/12), EUR. COMMISSION 1-2, http://ec.europa.eu/justice/data-protection/ files/ factsheets/factsheet_data_protection_en.pdf [https://perma.cc/QSK7-57UD]. 
processing of these data was harmful to Costeja. The CJEU explicitly held that violations of the Directive do not require any showing of "prejudice to the data subject." ${ }^{63}$ This is because data privacy is compromised whenever a data controller processes personal information in a manner that is irrelevant or no longer relevant for the specified purposes for which the information has been acquired, ${ }^{64}$ regardless of the existence of collateral personal or material harm. The point of data privacy is to protect the data subject's control over his personal information.

In the context of the La Vanguardia announcement, this instrumental logic may make a certain amount of sense. La Vanguardia was ordered to publish notice of the attachment proceedings to maximize the number of bidders. Presumably that purpose was satisfied many years before Costeja brought his complaint. At the time of Google Spain, therefore, there was no longer any reason for $L a$ Vanguardia to process Costeja's personal data by posting it online. Because official notices tend to serve explicit purposes of this kind, it is intelligible to limit the distribution of such notices to a temporal duration that corresponds to their objectives. ${ }^{65}$

The question is how this instrumental logic applies to Google. The purpose served by La Vanguardia's announcement is explicit and official. But what might it mean to conclude that Google's link to $L a$ Vanguardia's website is "inadequate, irrelevant or no longer relevant, or excessive in relation to the purposes" served by Google? One might as well inquire into the "specified purposes"66 for which a newspaper or a library circulates information. If personal data are processed without clear and explicit purposes, the logic of data privacy simply cannot get off the ground.

This difficulty is fundamental. The Directive applies to all "processing" of "personal data," and personal data is defined as all

63. Google Spain, supra note 12, para. 96; see FLORID1 ET AL., THE ADVISORY COUNCIL TO GOOGLE ON THE RIGHT TO BE FORGOTTEN 5 (2015), http://docs.dpaq.de/8527-report_of_the_ advisory_committee_to_google_on_the_right_to_be_forgotten.pdf [https://perma.cc/3LFC-5X VQ] ("[The] right to object to, and require cessation of, the processing of data about himself or herself . . . exists regardless of whether the processing at issue causes harm or is prejudicial in some way to the data subject.").

64. See, e.g., Viviane Reding, The Upcoming Data Protection Reform for the European Union, 1 INT'L DATA PRIVACY L. 4 (2011).

65. It is striking, however, that La Vanguardia was not required to take down its website.

66. Charter, supra note 9 , art. 8 (emphasis added). 
information "relating" to an identifiable person. ${ }^{67}$ There is no requirement that "personal data" be limited to private information or be limited to information that, if released, would be harmful to a data subject. ${ }^{68}$ Taken literally, personal data seem to include even "innocuous published information such as the name of an author coupled with a book title." 69

The Directive defines "processing" in equally expansive terms, as "any operation or set of operations which is performed upon personal data, whether or not by automatic means, such as collection, recording, organization, storage, adaptation or alteration, retrieval, consultation, use, disclosure by transmission, dissemination or otherwise making available, alignment or combination, blocking, erasure or destruction." ${ }^{70}$ Given these capacious definitions, the Directive on its face applies to multiple social domains that are not constructed according to a narrow instrumental logic.

So, for example, the Directive applies to the uploading of personal data to a website. The CJEU has held that making online references to personal information like a "telephone number or information regarding ... working conditions and hobbies ... constitutes the "processing of personal data."'71 Those who upload personal data to their websites are thus almost certainly "controllers" of data in the same sense as Google.

It is a fair guess that most personal websites are not constructed to achieve explicit purposes in the manner of the La Vanguardia announcement at issue in Google Spain. If you post a blog entry describing your best friend's birthday party, for example, you are processing personal data. ${ }^{72}$ What might it mean to ask whether your

67. See supra note 59 and accompanying text.

68. See supra note 63 and accompanying text.

69. David Erdos, From the Scylla of Restriction to the Charybdis of License? Exploring the Scope of the "Special Purposes" Freedom of Expression Shield in European Data Protection, 52 CAP. MKT. L. REV. 119, 122 (2015).

70. Directive, supra note 5, art. 2(b). The GDPR defines "processing" in virtually the same way. See GDPR, supra note 17, art. 4(2).

71. Case C-101/01, Criminal Proceedings Against Bodil Lindqvist, 2003 E.C.R. I-12992, I13008 para. 27. Because the GDPR defines the "processing" of data in the same way as does the Directive, GDPR, supra note 17, art. 4(2), this conclusion would also presumably apply to the GDPR.

72. And if your description reveals the racial identity of your friend or the fact that she has a cold, you have revealed what both the Directive and the GDPR call special categories of personal data, the disclosure of which is flatly prohibited, subject to certain narrowly drawn exceptions. See Directive, supra note 5, art. 8; GDPR, supra note 17, art. 9; see also Lindquist, 2003 E.C.R. I-12992, I-3014 to I-3015, para. 51 ("[R]eference to the fact that an individual has 
use of these data is "irrelevant or no longer relevant, or excessive" in light of the "purpose" for which you are writing your blog?

The question seems categorically misplaced, because you likely do not compose a blog to serve any single explicit purpose. You are instead probably engaged in what the German philosopher Jürgen Habermas would call communicative action. ${ }^{73}$ You wish to promote a dialogue with your friends and readers in ways that coordinate and affirm common social understandings. Someone who would ask whether processing personal data about your friend's birthday party has become "irrelevant" or "excessive" with respect to this purpose shows that they do not understand ordinary social practices. The personal data in your blog are not connected to the purpose for which you are writing the blog in the same way that a "means" is connected to an "end." In such contexts, the Directive poses unintelligible criteria for assessing the legitimacy of processing personal data.

The point is a deep one. Consider Article 8 of the Charter. It provides that personal data must be "processed fairly for specified purposes and on the basis of the consent of the person concerned or some other legitimate basis laid down by law"; that "[e]veryone has the right of access to data which has been collected concerning him or her, and the right to have it rectified"; and that "[c]ompliance with these rules shall be subject to control by an independent authority." ${ }^{74}$ Can you imagine complying with these bureaucratic rules in the context of posting personal data on a personal blog?

The conceptual architecture of Article 8 makes sense in the context of the large agglomerations of data that government or commercial organizations accrete and use. For such bureaucracies, data are merely a means to what James Rule once aptly characterized as "mass surveillance." 75 Organizations compile data to achieve specific ends. They engage in mass surveillance to determine creditworthiness or to minimize health costs. The structure of Article 8 seems well designed to ensure that in such contexts the processing of personal data

injured her foot and is on half-time on medical grounds constitutes personal data concerning health within the meaning of Article 8(1) of Directive 95/46.").

73. See generally JÜRGEN HABERMAS, KNOWLEDGE AND HUMAN INTERESTS (Jeremy J. Shapiro trans., Heinemann Educ. Books 1972) (1968); JÜrGEN HABERMAS, TOWARD A RAtional SOCIETY: Student PRotest, SCIENCE AND POLITICS 81-122 (Jeremy J. Shapiro trans., Beacon Press 1971) (1968).

74. Charter, supra note 9, art. 8 (emphasis added).

75. See James B. Rule, Private Lives and Public Surveillance: Social Control in THE COMPUTER AGE 300-58 (1974). 
be confined to appropriate ends and that they be answerable to the legitimate concerns of data subjects. ${ }^{76}$

But the intellectual architecture of Article 8 is mismatched to many ordinary human practices, even though such practices may involve what the Directive and the GDPR define as the processing of personal data. So, for example, the Directive and the GDPR provide that one "processes" personal data merely by keeping a "filing system" "7 that is not used "purely" for personal or household activities, like an address book that contains both personal friends and business acquaintances. ${ }^{78}$ If you keep such an address book, those you have listed are entitled to ask what information you have processed about them; to correct that information in your address book; to query whether that information is relevant or excessive for the purposes for which you have processed it; and to have these rights enforced by an independent authority. I find this all but unimaginable. It creates exactly the Big Brother that Article 8 is supposed to prevent.

A powerful government presence may be necessary to manage the large bureaucratic organizations that the GDPR and the Directive are constructed to regulate. Yet such formal obligations seem plainly out of place with respect to how ordinary people live their everyday lives. It is mistaken to hypostasize information by separating it from the

76. “Formal information systems are essential to large scale organizations, whether public or private, and these organizations are especially susceptible to the enforcement of information regulatory policies ...." George J. Stigler, An Introduction to Privacy in Economics and Politics, 9 J. LEGAL STUD. 623, 632 (1980).

77. The Directive defines a "filing system" as "any structured set of personal data which are accessible according to specific criteria." Directive, supra note 5, art. 2(c). The GDPR uses the same definition. GDPR, supra note 17, art. 4(6). The Directive states that it applies to "the processing of personal data wholly or partly by automatic means, and to the processing otherwise than by automatic means of personal data which form part of a filing system or are intended to form part of a filing system." Directive, supra note 5, art. 3(1). The GDPR has the same scope of application. GDPR, supra note 17 , art. 2(1).

78. Article 3(2) of the Directive provides that it "shall not apply to the processing of personal data . . by a natural person in the course of a purely personal or household activity." Directive, supra note 5, art. 3(2). The GDPR retains this same limitation. GDPR, supra note 17, art. 2(c); see $i d$. recital 18 ("This Regulation does not apply to the processing of personal data by a natural person in the course of a purely personal or household activity and thus with no connection to a professional or commercial activity. Personal or household activities could include correspondence and the holding of addresses, or social networking and online activity undertaken within the context of such activities." (emphasis added)); Directive, supra note 5, recital 12 (" $[\mathrm{P}]$ rotection principles must apply to all processing of personal data by any person whose activities are governed by Community law; whereas there should be excluded the processing of data carried out by a natural person in the exercise of activities which are exclusively personal or domestic, such as correspondence and the holding of records of addresses." (emphasis added)). 
social practices in which it is embedded. If information is used within bureaucratic structures that stress instrumental rationality, as happens in many large organizations, the deployment of information can properly be constrained by rules of instrumental rationality. But if information is instead integrated into the ordinary social practices that make up everyday life, it is wrongheaded to strangle those practices by imposing a procrustean bed of managerial restrictions. Why would we wish to imprison ordinary social communications within an "iron cage" of instrumental rationality? ${ }^{79}$ Yet the GDPR and the Directive each define "personal data" and data "processing" so abstractly and so comprehensively that they apply to aspects of life that no one would regard as managerial.

\section{B. Data Privacy, Dignitary Privacy, and the Public Sphere}

Both the GDPR and the Directive seek to foreclose this possibility by providing that their regulations will not apply to the processing of data "by a natural person in the course of a purely personal or household activity." ${ }^{80}$ But the world does not easily divide between a noninstrumental sphere that is "purely personal or household" and an instrumental sphere that encompasses everything else. To the contrary, and most relevant for our purposes, there is a public sphere of textuality that includes what we might call the reading public. ${ }^{81}$ The CJEU has held that making data "accessible to an indefinite number of people" online cannot be exempted from the requirements of the Directive because it is not for "personal" or "domestic" use. ${ }^{82}$

The public sphere is characterized by communicative action, not

79. Max Weber, The Protestant Ethic and the SPIRIT OF CaPITAlism 181 (Talcott Parsons trans., Unwin 1965) (1930); see GIOVANNA BORRADORI, PHILOSOPHY IN A TIME OF TERror: Dialogues WITH JÜrgen HABERMAS AND JACQUES DERRIDA 71 (2003).

80. GDPR, supra note 17, art. 2(2)(c) (emphasis added); Directive, supra note 5, art. 3(2) (emphasis added); see supra note 78.

81. Consider in this light Opinion 5/2009 of the Article 29 Data Protection Working Party, which provides that those who use social networking sites (SNSs) "as a platform to advance commercial, political or charitable goals," assume "the full responsibilities of a data controller" under the Directive. ARTiCle 29 Data Prot. Working PARTY, OPINION 5/2009: ON ONLINE SOCIAL NETWORKING 6 (2009), http://ec.europa.eu/justice/data-protection/article-29/documentation/opinion-recommendation/files/2009/wp163_en.pdf [https:/perma.cc/824V-PV2P]. SNS users who "acquire a high number of third party contacts, some of whom he may not actually know," should be aware "that the household exception does not apply and therefore that the user would be considered a data controller." Id. The household exemption, in other words, stops at the threshold of the reading public.

82. Case C-101/01, Criminal Proceedings Against Bodil Lindqvist, 2003 E.C.R. I-12992, I13013 to I-13014, paras. 46-47; see supra note 81. 
instrumental reason. Google has become an essential resource for the public sphere. Consider how I came to write this article, which is meant as a contribution to the public sphere. I used Google to access and learn from texts all around the world. Some of these texts, such as the GDPR and the Directive, did not contain personal data. But many did; they offered information about how Google Spain and the Directive have affected the behavior of actual people.

The analytic framework of Article 8 is incompatible with my use of these data to engage in public discussion. The point of fair information practices is to give ordinary persons "control" over their own personal data. ${ }^{83}$ The GDPR makes this explicit when it affirms that "[n]atural persons should have control of their own personal data." ${ }^{84}$ If the question is whether the personal information produced by structures of mass surveillance should be controlled by bureaucratic

83. See Org. For ECON. Co-Operation \& Dev., THE OECD PrivaCy Framework 41 (2013); Joel R. Reidenberg, Resolving Conflicting International Data Privacy Rules in Cyberspace, 52 STAN. L. REV. 1315, 1325-26 (2000). Orla Lynskey observes that Google Spain "provides implicit support for the recognition of 'individual control over personal data', irrespective of whether these personal data are 'private', as a fundamental aspect of the right to data protection. Data protection experts have long-suggested that this control, sometimes referred to in stronger terms as 'informational self-determination', is a central aspect of data of data protection." Orla Lynskey, Control over Personal Data in a Digital Age: Google Spain v AEPD and Mario Costeja Gonzalez, 78 MOD. L. REV. 522, 529 (2015).

84. GDPR, supra note 17 , recital 7. Contemporaneous analysis synthesized the goals of the GDPR:

The other goal of the GDPR is to provide individuals with a stronger control on their personal data, so as to restore consumers' trust in the digital economy. To this end, the new legislative framework updates some of the basic principles set out by Directive 95/46/EC - which are believed to 'remain sound' (Recital 9) - and devises some new ones, in order to further buttress the position of data subjects with respect to their own data.

The power of individuals to access and control their personal data is strengthened, inter alia, by the introduction of a 'right to be forgotten' (Article 17) and a right to data portability, aimed at facilitating the transmission of personal data between service providers (Article 20). The data subject additionally acquires a right to be notified, 'without undue delay' of any personal data breach which may result in 'a high risk to [his or her] rights and freedoms' (Article 33).

Pietro Franzina, The EU General Data Protection Regulation: A Look at the Provisions That Deal Specifically with Cross-Border Situations, ConflictofLaws.NET (May 10, 2016), http:// conflict oflaws.net/2016/the-eu-general-data-protection-regulation-a-look-at-the-provisions-that-dealspecifically-with-cross-border-situations/ [https://perma.cc/MAJ3-AFL3] (alteration in original); see also Edward J. Eberle, Human Dignity, Privacy, and Personality in German and American Constitutional Law, 1997 UTAH L. REV. 963, 1001-02 ("Ultimately this concept of control over personal data stems from the influential Census Act Case of the German Federal Constitutional Court, which created 'a general right of informational self-determination' protecting 'the authority of the individual to decide fundamentally for herself, when and within what limits personal data may be disclosed."). 
organizations or by the natural persons whose lives are affected by such organizations, it may make sense to award the authority of "control" to natural persons, subject to a few well-defined exceptions. ${ }^{85} \mathrm{But}$ if we imagine a social world that does not consist of persons struggling against large, impervious bureaucratic organizations, but instead of individuals engaged in continuous dialogue, like the debate I hope will be prompted by this article, "control" is simply the wrong metaphor to apply. ${ }^{86}$ The metaphor of "control" almost implies that personal information is in some sense "owned" by particular persons. ${ }^{87}$

Consider public consideration of Hillary Clinton's emails or of Donald Trump's connections to Russia. Although discussion of such matters would include a great deal of personal data, it makes little sense to ask who "controls" those data. In matters of legitimate public concern, we wish to promote an ongoing public dialogue that involves a common search for meaning in light of shared facts. It would effectively shut down this search if personal data were construed to be under the "control" of one person or another.$^{88}$ This is an important point for understanding the relationship between data privacy and the freedom of speech necessary to sustain democracy.

We can roughly define democracy as "government by public

85. I take this to be the central point of Daniel Solove's argument that the primary metaphor for invasions of privacy ought not to be "Big Brother," but instead "Franz Kafka's depiction of bureaucracy in The Trial-a more thoughtless process of bureaucratic indifference, arbitrary errors, and dehumanizations, a world where people feel powerless and vulnerable, without any meaningful form of participation in the collection and use of their information." Daniel J. Solove, Privacy and Power: Computer Databases and Metaphors for Information Privacy, 53 STAN. L. REV. 1393, 1398 (2001) (footnote omitted) (citing FRANZ KAFKA, THE TRIAL (Willa Muir \& Edwin Muir trans., 1937)). Solove aptly observes:

The problem with databases... involves power and the effects of our relationship with public and private bureaucracy-our inability to participate meaningfully in the collection and use of our personal information. As a result, we must focus on the structure of power in modern society and how to govern such relationships with bureaucracies.

Id. at 1461; see id. at 1436; see also Paul M. Schwartz, Privacy and Democracy in Cyberspace, 52 VAND. L. REV. 1609, 1612, 1641 (1999) (describing how the Internet "permits the creation of a new power structure in which scant room exists for privacy"). It might also be the case, however, that the law might more effectively address some issues arising from the accumulation of mass data through the normative concept of "information fiduciaries" than through the abstract principle of "control." See, e.g., Jack Balkin, Information Fiduciaries and the First Amendment, 49 U.C. DAVIS L. REV. 1183 (2016).

86. See Paul M. Schwartz, Beyond Lessig's Code for Internet Privacy: Cyberspace Filters, Privacy Control, and Fair Information Practices, 2000 WIS. L. REV. 743, 760-61.

87. Bert-Jaap Koops, Forgetting Footprints, Shunning Shadows. A Critical Analysis of the "Right To Be Forgotten" in Big Data Practice, 8 SCRIPTED 229, 246-47 (2011).

88. See Weber, supra note 41, at 125. 
opinion. ${ }^{" 89}$ It is for this reason that democracy requires the freedom of speech necessary to form public opinion. ${ }^{90}$ I use the term "public discourse" to refer to the set of communications constitutionally deemed necessary to form democratic public opinion..$^{91}$ Democracy presupposes that dialogue within public discourse is intersubjective rather than instrumental. ${ }^{92}$ The shared facts necessary for such dialogue are inconsistent with a legal order that would authorize individuals to withdraw personal data from circulation whenever they believe it desirable.

Article 8 of the Charter is written so entirely within a matrix of managerial rationality that it effaces every other normative structure of communication. It does not recognize public discourse as an alternative field of human interaction. Taken literally, therefore, the conceptual architecture of Article 8 would eliminate the possibility of democratic legitimation. Both the Directive and the GDPR recognize this difficulty. Seeking to implement Article 8 in a manner that would render it compatible with the Charter's commitment to "freedom of expression" in Article 11,93 they grudgingly exempt some public discourse from the reach of their managerial requirements.

The Directive provides "exemptions or derogations ... for the processing of personal data carried out solely for journalistic," artistic, or literary purposes, but these exceptions may be used only when "necessary to reconcile the right to privacy with the rules governing freedom of expression." 94 The GDPR more generously instructs

89. CARl SChmitt, CONSTItutional Theory 275 (Jeffrey Seitzer ed., trans., Duke Univ. Press 2008) (1928).

90. See Robert C. Post, Democracy, EXPertise, AND ACAdEMIC FreEdom: A First AMENDMENT JURISPRUDENCE FOR THE MODERN STATE 13-21 (2012).

91. Id. at 15. In this article I am not using the term "public discourse" to refer to those speech acts that in American constitutional law would create the value of democratic legitimation for individual human beings. Contra RoBert C. POST, CITIZENS DIVIDED: CAMPAIGN FINANCE REFORM AND THE CONSTITUTION 71-74 (2014).

92. See Frank Michelman, Law's Republic, 97 YAle L.J. 1493, 1526-27 (1988).

93. Article 11 of the Charter of Fundamental Rights provides:

1. Everyone has the right to freedom of expression. This right shall include freedom to hold opinions and to receive and impart information and ideas without interference by public authority and regardless of frontiers.

2. The freedom and pluralism of the media shall be respected.

Charter, supra note 9 , art. 11.

94. Directive, supra note 5, art. 9. For an exhaustive and disquieting study of how the national law of EU member states seeks (or does not seek) to reconcile the Directive with journalistic freedom, see generally David Erdos, European Union Data Protection Law and Media Expression: Fundamentally Off Balance, 65 INT'L CoMP. L.Q. 139 (2016); David Erdos, Statutory Regulation of Professional Journalism Under European Data Protection: Down but Not 
Member States to "reconcile the right to the protection of personal data ... with the right to freedom of expression and information, including processing for journalistic purposes and the purposes of academic, artistic or literary expression." 95

The important theoretical question, then, is how "freedom of expression and information" 96 may be reconciled with the data privacy established by Article 8 . Neither the Directive nor the GDPR offers so much as a hint. ${ }^{97}$ When pressed, reconciliation is explained through the metaphor of striking "a balance between [data] privacy and freedom of expression." ${ }^{98}$ But it is hard to understand how balancing can occur when data privacy and freedom of expression presuppose mutually exclusive social domains. The possibility of public discourse is foreclosed if personal data must be processed according to the managerial logic of data privacy, ${ }^{99}$ but fair information practices are

Out? 8 J. MEDIA L. 229 (2016); and David Erdos, European Regulatory Interpretation of the Interface between Data Protection and Journalistic Freedom: An Incomplete and Imperfect Balancing Act (Cambridge Legal Stud. Res. Paper Series, Paper No. 61/2015, 2015).

95. GDPR, supra note 17 , art. $85(1)$.

96. In the European context, citizens have the right "to receive and impart information." See Charter, supra note 9, art. 11 (emphasis added).

97. This is especially disturbing because the GDPR goes out of its way to emphasize that the burden of proof is squarely on those who would preserve personal data from the RTBF. Article 17 provides that a controller "shall have the obligation to erase personal data without undue delay" unless "processing is necessary for exercising the right of freedom of expression and information .... [or] for archiving purposes in the public interest, scientific or historical research purposes or statistical purposes ...." GDPR, supra note 17, art. 17 (emphasis added).

98. WORKING PARTY ON THE PROT. OF INDIVIDUALS WITH REGARD TO THE PROCESSING of PERs. DATA, ReCOMMENDATION 1/97: DATA PROTECTION LAW AND THE MEdia 5 (1997), http://ec.europa.eu/justice/policies/privacy/docs/wpdocs/1997/wp1_en.pdf [https:/perma.cc/AH N8-AMCX]; see Directive, supra note 5, recital 37; David Hoffman, Paula Bruening \& Sophia Carter, The Right to Obscurity: How We Can Implement the Google Spain Decision, 17 N.C. J.L. \& TECH. 437, 457-59 (2016).

99. See Post, supra note 48, at 1788-90. In Italy, where the national data privacy law does not contain an exception for journalistic activities, digital newspaper articles can be assessed damages if they are not taken offline when they are posted "for a period of time . . beyond that which is necessary for the purposes for which" they have been written. Athalie Matthews, How Italian Courts Used the Right To Be Forgotten To Put an Expiry Date on News, GuARdiAn (Sept. 20, 2016), https:/www.theguardian.com/media/2016/sep/20/how-italian-courts-used-the-right-to-beforgotten-to-put-an-expiry-date-on-news?CMP=share_btn_tw [https://perma.cc/R9QM-V873] (internal quotations omitted). The implications of this policy for public discourse are truly terrifying:

The highest court in Italy recently upheld a ruling that, after a period of two years, an article in an online news archive had expired, "just like milk, yoghurt or a pint of icecream".

$\ldots$

[I]n Italy at least, 'the right to be forgotten' now has a new meaning: the right to remove inconvenient journalism from archives after two years. 
eliminated if public discourse is exempted from this logic and allowed to follow a free play of ideas and interests. How data privacy might be safeguarded within public discourse is unexplained, because data privacy exists in a bureaucratic universe that is incompatible with the communicative action constitutive of the public sphere. ${ }^{100}$

In this respect, the RTBF established by the Directive and the GDPR stands in stark contrast to the right to be forgotten. The law of the United States ${ }^{101}$ and of a number of European nations, ${ }^{102}$ as well as that of the European Convention, ${ }^{103}$ has long used the right to be forgotten to reconcile the value of dignitary privacy with public discourse. In essence the right to be forgotten asks whether particular communications have become so offensive as defined by "community mores" that they cannot be said to satisfy "a legitimate interest or curiosity" 104 of the public. ${ }^{105}$ Communications that seriously violate

This surely cannot be right. If it was, everyone would demand deletions from news websites and online journalism would be decimated.

…

[T]he Italian code dictates that 'data must be kept in a form which allows identification for a period of time not beyond that which is necessary for the purposes for which they were collected.'

However ... journalism is not exempted from this 'time limit' ....

This leaves Italian editors vulnerable to arguments that their product has 'now been published for long enough' and must be taken down.

Indeed, the supreme court followed precisely this reasoning in concluding: "The time passed between the date it [the article] was first published and the date when its removal was requested, sufficed to satisfy the public interest as far as its right to be informed was concerned, and that therefore, at least from the date when the formal notice was received, that data could no longer be disclosed."

Whether the 'out of date' stamp issued to a two-year-old article will now be applied elsewhere remains to be seen.

Id. (third alteration in original).

100. Our conception of privacy, as Jack Hirshleifer once notably observed, signifies "a particular kind of social structure together with its supporting social ethic." Jack Hirshleifer, Privacy: Its Origin, Function, and Future, 9 J. LEGAL STUD. 649, 649 (1980).

101. See supra notes 36,39 ; infra notes $104-07$.

102. See, e.g., Jeanne M. Hauch, Protecting Private Facts in France: The Warren \& Brandeis Tort Is Alive and Well and Flourishing in Paris, 68 TUL. L. REV. 1219 passim (1994); Mantelero, supra note 40, at 229 n.1; Basil Markesinis, Colm O'Cinneide, Jörg Fedtke \& Myriam HunterHenin, Concerns and Ideas About the Developing English Law of Privacy (and How Knowledge of Foreign Law Might Be of Help), 52 AM. J. COMP. L. 133 passim (2004); Werro, supra note 39, passim; James Q. Whitman, The Two Western Cultures of Privacy: Dignity Versus Liberty, 113 YALE. L.J. 1151 passim (2004).

103. See supra notes 32-36; infra note 121.

104. Virgil v. Time, Inc., 527 F.2d 1122, 1131 (9th Cir. 1975), cert. denied, 425 U.S. 998 (1976).

105. Haynes v. Alfred A. Knopf, Inc., 8 F.3d 1222, 1232 (7th Cir. 1993). When the first Restatement of Torts recognized the tort of invasion of privacy in 1939 , it explicitly observed that the protection of privacy must be "relative to the customs of the time and place and to the habits and occupation of the plaintiff." RESTATEMENT (FIRST) OF TORTS $\$ 867 \mathrm{cmt}$. c (AM. LAW. INST. 
norms of privacy are conceived as causing harm like "humiliation and mortification." 106 This approach does not focus on personal data per se, but instead seeks to ascertain whether specific communications are consistent with what I have elsewhere called "civility rules"normative standards of behavior that reciprocally define both individual and community identity. ${ }^{107}$ It asks whether communications are appropriate, meaning in accordance with "finely calibrated systems of social norms, or rules ... [that] define and sustain essential activities and key relationships and interests." ${ }^{108}$ Communications that are sufficiently outrageous are regarded as damaging to human personality.

The right to be forgotten stands in a different relationship to public discourse than does the RTBF. The RTBF is incompatible with public discourse because persons do not engage in public discussion for predetermined and "specified purposes,"109 and because the intersubjective field of public discourse is irreconcilable with the right of individual data subjects to "control" personal information "relating to" themselves. ${ }^{110}$ By contrast, although the right to be forgotten may constrain what might be said in public discussion, and so be in tension with freedom of expression, it is not necessarily incompatible with the democratic function of public discourse.

Freedom of expression empowers persons to participate in the formation of public opinion and hence to experience the state as potentially responsive to them. ${ }^{111}$ It is for this reason that freedom of

1939).

106. Pavesich v. New England Life Ins. Co., 50 S.E. 68, 80 (Ga. 1905). Similarly, courts have recognized that:

[t]here must be ... some reasonable and plausible ground for the existence of this mental distress and injury. It must not be the creation of mere caprice nor of pure fancy, nor the result of a supersensitive and morbid mental organization, dwelling with undue emphasis upon the exclusive and sacred character of this right of privacy. ... [A] violation of a legal right, must ... be of such a nature as a reasonable man can see might and probably would cause mental distress and injury to any one possessed of ordinary feeling and intelligence.

Schuyler v. Curtis, 42 N.E. 22, 26 (N.Y. 1895). For a discussion of the sociological interconnection between community mores and damage to personality, see Robert C. Post, The Social Foundations of Privacy: Community and Self in the Common Law Tort, 77 CALIF, L. REV. 957 (1989).

107. See Post, supra note 106, at 962-63, 978-87.

108. Helen Nissenbaum, Privacy in Context: Technology, Policy, and the INTEGRITY OF SOCIAL LIFE 2-3 (2010).

109. Charter, supra note 9 , art. 8.

110. See supra notes $86-88$ and accompanying text.

111. Post, supra note 91 , at 39-42. 
speech is generally regarded as essential to democracy. ${ }^{112}$ But if public discourse becomes sufficiently abusive and alienating, persons are unlikely to experience it as a medium through which they might influence the construction of public opinion. In such circumstances, public discourse will no longer serve the purpose of democratic legitimation and hence the democratic justification for freedom of speech will pro tanto diminish.

This creates what I have elsewhere called "the paradox of public discourse"-public discourse can sustain democratic legitimation only if it is conducted with a modicum of civility, yet the enforcement of civility constrains freedom of speech. ${ }^{113}$ Different legal systems resolve the paradox of public discourse in different ways. The very existence of the paradox, however, demonstrates that the right to be forgotten can be compatible with the democratic function of public discourse in ways that the RTBF cannot.

In almost all its manifestations, the right to be forgotten seeks to reconcile dignitary privacy with public discourse by roughly balancing harms to personality against harms to public discourse. This is contrary to the approach of the Directive, which asks only if data processing is "inadequate, irrelevant or no longer relevant, or excessive in relation to the purposes of the processing at issue carried out by the operator of the search engine." 114 Google Spain adopted the Directive's approach when it went out of its way to emphasize that violations of the RTBF could be determined independently of any "prejudice to the data subject." 115 Without a conception of harm, however, the CJEU effectively deprived itself of the most elementary conceptual resource for reconciling the RTBF with the public discourse necessary for democratic legitimation.

112. As a constitutional right, of course, freedom of speech is in one sense inconsistent with democracy because it is used to invalidate otherwise democratic and majoritarian legislation. Some theories of freedom of expression seek to overcome this paradox by stressing the importance in a democracy of communicating information to voters. See generally ALEXANDER Meiklejohn, Political Freedom: The Constitutional PoWers of the People (1965). Such theories stress the right of listeners to receive information. By contrast, theories that stress the right of speakers to express themselves typically rest on the relationship between speech and the underlying responsiveness of a democratic government. See Robert C. Post, Participatory Democracy and Free Speech, 97 VA. L. REV. 477, 484-85 (2011).

113. Robert C. Post, The Constitutional Concept of Public Discourse: Outrageous Opinion, Democratic Deliberation, and Hustler Magazine v. Falwell, 103 HARV. L. REV. 601, 640-44, 68084 (1990).

114. Google Spain, supra note 12, para. 94.

115. Id. para. 96. 


\section{Ambiguities in the Google Spain Opinion}

The CJEU was therefore caught in an intellectually intolerable position. It solved this problem by constructing an analytic framework that moved beyond the four corners of the Directive. Seeking to explain why the Directive might require the erasure of Google's listings but not of La Vanguardia's original webpage, which after all contained the actual objectionable personal data, the CJEU asserted:

Indeed, since the inclusion in the list of results, displayed following a search made on the basis of a person's name, of a web page and of the information contained on it relating to that person makes access to that information appreciably easier for any internet user making a search in respect of the person concerned and may play a decisive role in the dissemination of that information, it is liable to constitute a more significant interference with the data subject's fundamental right to privacy than the publication on the web page. ${ }^{116}$

This reasoning turns on the premise that some violations of privacy are "more significant" than others. But this premise cannot be found in the Directive, which avoids any such concept of harm and seeks instead to entrench a data subject's abstract right to "control" his personal data. At a later point in its opinion, the CJEU referred explicitly to "the sensitivity for the data subject's private life of the information contained in" the La Vanguardia "announcements." 117 But the idea that some personal data are more sensitive than others is not a concept contained in the Directive. ${ }^{118}$

From what source, then, did the CJEU derive a "fundamental right to privacy" that could be violated in more or less "significant" ways? As best I can make out, the CJEU seemed to be appealing to the dignitary privacy contained in Article 7 of the Charter. ${ }^{119}$ In striking contrast to Article 8, which makes sense only within a social space that is bureaucratically organized, Article 7 invokes the contextual civility rules that define the right to be forgotten. ${ }^{120}$ Because Article 7 of the

116. Id. para. 87

117. Id. para. 98 .

118. Both the Directive and the GDPR designate certain "special categories of personal data," as to which especially strict regulations apply. Directive, supra note 5, art. 8; GDPR, supra note 17 , art. 9. These categories may be thought to designate personal data that may cause particular harm if misused. The data at issue in Google Spain were not included within these "special categories of personal data."

119. The CJEU refers explicitly to the fundamental rights created by Article 7 as one ground of Costeja's complaint. Google Spain, supra note 12, para. 99.

120. For a discussion of the differences between a right of privacy and an independent right 
Charter incorporates the ECtHR's interpretations of Article 8 of the European Convention, the right to be forgotten is likely included in the Charter. The ECtHR interprets the right to be forgotten to protect dignity against violations of civility rules that can cause greater or lesser harms. ${ }^{121}$ Such civility rules might also justify the conclusion that disclosure of information about a sensitive and embarrassing bankruptcy is more "harmful" than the disclosure of other forms of personal data. ${ }^{122}$

The difficulty is that the framework of Article 7 is foreign to the conceptual architecture of the Directive, which exemplifies the fair information practices established by Article 8 . The dignitary privacy of Article 7 seeks to protect human personality from the damage caused by communications that flout essential norms of respect. Because these norms are value-laden and contextual, so is the dignitary privacy protected by Article 7, which imagines human personality as essentially social. By contrast, the data privacy safeguarded by Article 8 creates fair information practices that establish bureaucratic rules to structure the decisionmaking of persons who are figured as asocial and autonomous. ${ }^{123}$

to data protection, see generally Orla Lynskey, Deconstructing Data Protection: The 'AddedValue' of a Right to Data Protection in the EU Legal Order, 63 INT'L \& COMP. L.Q. 569 (2014). Lynskey concludes that the CJEU has consistently conflated "the rights to data protection and privacy." Id. at 574-75. She notes that "unlike the notion of 'privacy interference,' the concept of 'personal data' is not context-dependent." Id. at 583. Cf. Julia Ballaschk, In the Unseen Realm: Transnational Intelligence Sharing in the European Union-Challenges to Fundamental Rights and Democratic Legitimacy, 51 STAN. J. INT'L L. 19, 22-24 (2015) (explaining that the right to privacy is a broad concept, within which lies the right to data protection-essentially, the right to determine which information about oneself is known to others).

121. The European Court of Human Rights has interpreted the dignitary privacy rights of Article 8 of the Convention to be context dependent and to authorize courts to categorize communicative invasions of privacy that produce a "more or less strong sense of intrusion." Couderc \& Hachette Filipacchi Associés v. France, Case No. 40454/07, paras. 86-87, 93 (Eur. Ct. H.R., Nov. 10, 2015), http://hudoc.echr.coe.int/eng?i=001-158861 [https://perma.cc/U7GAEXXT]. The ECtHR's interpretation of Article 8 of the Convention are directly applicable to the meaning of Article 7 of the Charter. See supra note 31.

122. See, e.g., Brents v. Morgan, 299 S.W. 967, 971 (Ky. 1927) (holding actionable a plaintiff's claim for invasion of privacy against a defendant who published information regarding plaintiff's debt); Post, supra note 106, at 979-81. It is fascinating that the Directive does not classify financial data of the kind at issue in Google Spain as a special category of personal data. Directive, supra note 5, art. 8; see GDPR, supra note 17, art. 9.

123. Some have described the right to data privacy as a

proactive tool to reduce power and information asymmetries as it strengthens the hand of the individual vis-á-vis data controllers and processors. In this regard, the regulatory origins of the right to data protection become apparent as these power and information asymmetries are market failures which data protection legislation seeks to correct.

Lynskey, supra note 120 , at 592. 
The CJEU never acknowledged this tension. It seemed determined to rest Costeja's claim on the entirely instrumental premise that the Google link was "inadequate, irrelevant or no longer relevant, or excessive in relation to the purposes of the processing at issue carried out by the operator of the search engine." 124 The result was neither fish nor fowl; the CJEU purported to apply the logic of the Directive but in fact smuggled in normative considerations of harm appropriate to Article 7 .

The resulting confusion intensified as the CJEU scrambled to determine how the bureaucratic logic of the Directive could be rendered compatible with the open processes of public opinion formation necessary for democratic legitimacy in a modern state. ${ }^{125}$ In negotiating this difficulty, the CJEU was forced to take yet another step away from the conceptual architecture of the Directive. It explained that a data subject's control of personal data could be overridden when it was found "for particular reasons, such as the role played by the data subject in public life, that interference with his fundamental rights is justified by the preponderant interest of the general public in having, on account of inclusion in the list of results, access to the information in question." 126

There is nothing in the conceptual architecture of the Directive to suggest that some data subjects ought to have less control over personal data than others. ${ }^{127}$ The CJEU apparently introduced this distinction because it believed it necessary to protect freedom of expression. ${ }^{128} \mathrm{But}$

124. Google Spain, supra note 12, para. 94; see Eloïse Gratton \& Jules Polonetsky, Droit à l'oubli: Canadian Perspective on the Global 'Right to be Forgotten' Debate, 15 COL. TECH. L.J. 337, 367-68 (2017); Hillary C.. Webb, Note, "People Don't Forget": The Necessity of Legislative Guidance in Implementing a U.S. Right To Be Forgotten, 85 GEO. WASH. L. REV. 1304, 1325 (2017).

125. See POST, supra note 90 , at 17-18.

126. Google Spain, supra note 12, para. 97.

127. As the former European Data Protection Supervisor, Peter Hustinx, has noted, "the right to data protection," in contrast to the "right to privacy," is not sensitive to the public figure status of a data subject. "The applicability of the law on data protection is not dependent on people's entitlement to privacy in the handling of their personal information." See Peter Hustinx, Informationsfreiheit und Datenschutz in der Europaïschen Union, in DATENSCHUTZ: GRUNDLAGEN, ENTWICKLUNGEN UND KONTROVERSEN 322, 322-30 (Jan-Hinrik Schmidt \& Thilo Weichert eds., 2012).

128. The Directive provides that "Member States shall provide for exemptions or derogations from the provisions of [the Directive] . . for the processing of personal data carried out solely for journalistic purposes or the purpose of artistic or literary expression only if they are necessary to reconcile the right to privacy with the rules governing freedom of expression." Directive, supra note 5, art. 9. Freedom of expression under Article 11 of the Charter refers to the right to receive information, see supra note 93 , and it is perhaps to that right that the CJEU is referring when it 
the distinction required the CJEU to explain how the public might come to enjoy a "preponderant interest" in the personal information of a data subject. ${ }^{129}$

Any such explanation must ultimately rest on an account of the

states that:

inasmuch as the removal of links from the list of results could, depending on the information at issue, have effects upon the legitimate interest of internet users potentially interested in having access to that information, in situations such as that at issue in the main proceedings a fair balance should be sought in particular between that interest and the data subject's fundamental rights under Articles 7 and 8 of the Charter. Whilst it is true that the data subject's rights protected by those articles also override, as a general rule, that interest of internet users, that balance may however depend, in specific cases, on the nature of the information in question and its sensitivity for the data subject's private life and on the interest of the public in having that information, an interest which may vary, in particular, according to the role played by the data subject in public life.

Google Spain, supra note 12, para. 81 (emphasis added); see ARTICLE 29 DATA Prot. WORKING PARTY, GUIDELINES ON THE IMPLEMENTATION OF THE COURT OF JUSTICE OF THE EUROPEAN UNION JUDGMENT ON "GOOGLE SPAIN AND INC. V. AGENCIA ESPAÑOLA DE PROTECCIÓN DE DATOS AND MARIO COSTEJA GONZALEZ" C-131/12, para. 8 (2014), http://www. dataprotection.ro/servlet/ViewDocument?id=1080 [https://perma.cc/GH56-R74K] ("The interest of search engines in processing personal data is economic. But there is also an interest of internet users in receiving the information using the search engines. In that sense, the fundamental right of freedom of expression, understood as 'the freedom to receive and impart information and ideas' in Article 11 of the European Charter of Fundamental Rights, has to be taken into consideration when assessing data subjects' requests."); Joris van Hoboken, Search Engine Law and Freedom of Expression. A European Perspective, FUTURE NON STOP (2009), http://futurenonstop.org/c/ a2ece341ce5fbc00f9fc58151da8f981 [https://perma.cc/9XJD-6LNQ].

129. American courts sometimes conclude that persons who have sought to play a role "in public life" waive their right to privacy. "A person - who by his accomplishments, fame, or mode of life, or by adopting a profession or calling which gives the public a legitimate interest in his doings, affairs, or character-is said to become a public personage, and thereby relinquishes a part of his right of privacy." Cohen v. Marx, 211 P.2d 320, 321 (Cal. Dist. Ct. App. 1949); see Kapellas v. Kofman, 459 P.2d 912, 923 (Cal. 1969) (en banc). Such a person cannot "at his will and whim draw himself like a snail into his shell and hold others liable for commenting upon the acts which had taken place when he had voluntarily exposed himself to the public eye. As to such acts he had waived his right of privacy and he could not at some subsequent time rescind his waiver." Cohen, 211 P.2d at 321.

This reasoning focuses on the nature of the social norms that define the value of dignitary privacy; it specifies the relationship between these norms and concepts like waiver and assumption of the risk. In a European context, this reasoning might be incorporated into the normative interpretations of privacy required by Article 7. But this reasoning tells us nothing about how to evaluate "the interest of the general public" in receiving information. As Kenneth Karst once trenchantly pointed out, the reasoning is almost certainly inadequate to explain why public figures have diminished rights of privacy. It is "surely mistaken," Karst wrote, to believe

that the decisions denying public figures damages for invasion of privacy are based on a consent theory. ... If the mayor or the starlet were expressly to withhold consent to publication, the result would not be changed... The reason is not that they have consented to the publicity but that the publicity is justified in the public interest, whether or not they consent.

Kenneth L. Karst, "The Files": Legal Controls over the Accuracy and Accessibility of Stored Personal Data, 31 L. \& CONTEMP. PROBS. 342, 345 (1966). 
communicative processes required by a democracy. The Directive does not offer any assistance in this regard. ${ }^{130}$ It merely refers to "freedom of expression." $" 131$ For its part, the CJEU does not elucidate what it means by a "predominant interest of the general public." It simply asserts, in the climactic paragraph of its opinion:

As the data subject may, in the light of his fundamental rights under Articles 7 and 8 of the Charter, request that the information in question no longer be made available to the general public on account of its inclusion in such a list of results, those rights override, as a rule, not only the economic interest of the operator of the search engine but also the interest of the general public in having access to that information upon a search relating to the data subject's name. However, that would not be the case if it appeared, for particular reasons, such as the role played by the data subject in public life, that the interference with his fundamental rights is justified by the preponderant interest of the general public in having, on account of its inclusion in the list of results, access to the information in question. ${ }^{132}$

In this crucial paragraph, the CJEU cites inconsistent sources of law to create a truncated, but more or less explicit, balancing inquiry. ${ }^{133}$ On one side there are the harms to privacy inflicted by the Google link. These harms are defined in ways that echo the civility norms of Article 7 insofar as the CJEU can characterize them as especially "significant." 134 On the other side, there is the absence of "particular reasons" to justify a special public interest in securing the information that would be produced by "a search relating to the data subject's name." Google itself, the CJEU is careful to add, has no interest in maintaining the link in question apart from its "economic interest." Hence the outcome of the "balance" is that the Google link must be removed. ${ }^{135}$

\footnotetext{
130. Neither does the GDPR.

131. Directive, supra note 5, art. 9.

132. Google Spain, supra note 12, para. 99.

133. See supra note 128.

134. Google Spain, supra note 12, para. 87.

135. The court concisely articulated this balance, explaining:
}

In the light of the potential seriousness of [the interference in the data subject's privacy rights] ... it is clear that it cannot be justificd by merely the economic interest which the operator of such an engine has in that processing. However, inasmuch as the removal of links from the list of results could, depending on the information at issue, have effects upon the legitimate interest of internet users potentially interested in having access to that information, in situations such as that at issue in the main proceedings a fair balance should be sought in particular between that interest and the 
The methodology of this paragraph is entirely outside the legal universe of the Directive, which is a sure sign that the CJEU is attempting to apply the Directive to a domain of social life for which it is mismatched. Because the GDPR will inevitably suffer the same mismatch when its RTBF is applied to search engine links, it is worth thinking carefully about the kind of balance struck by the CJEU in Google Spain. For present purposes, I accept the privacy value ascribed by the CJEU to Costeja's particular information. But I interrogate the "public interest" attributed by the CJEU to the Google link.

The CJEU found an insufficient public interest to limit the application of the Directive because Costeja had not sought to play a role in public life. This is an obviously incomplete account of the public interest in the circulation of information. ${ }^{136}$ The public certainly has strong interests in acquiring personal data with respect to persons who for malevolent reasons-like the commission of crime-seek to avoid the glare of publicity. ${ }^{137}$ This suggests that the interests of the public cannot be confined to the personal data of those who already play a large role in public life. In a democracy, the public interest must extend to information about anything that can or will become part of the agenda of public action. ${ }^{138}$ This is a far broader interest than that acknowledged by the CJEU. It is in fact so broad that it is difficult to cabin.

More subtly, and more importantly, the public also has a fundamental interest in maintaining the integrity of the structure of communication that makes public discourse possible. This interest persists regardless of the specific content of particular communications

data subject's fundamental rights under Articles 7 and 8 of the Charter. Whilst it is true that the data subject's rights protected by those articles also override, as a general rule, that interest of internet users, that balance may however depend, in specific cases, on the nature of the information in question and its sensitivity for the data subject's private life and on the interest of the public in having that information, an interest which may vary, in particular, according to the role played by the data subject in public life.

Id. para. 81 .

136. On the narrowness of the Google Spain's conception of freedom of expression, see Jens van den Brink, Missed Opportunity: Dutch Supreme Court Copy-Pastes Google Spain Judgment, INFORRM's BLOG (May 6, 2017), https://inforrm.wordpress.com/2017/05/06/missed-opportunitydutch-supreme-court-copy-pastes-google-spain-judgment-jens-van-de-brink/ [https://perma.cc/ G9VR-HUPW].

137. Cf. Von Hannover v. Germany (no. 2), 2012-I Eur. Ct. H.R. 351 (conceptualizing the "vital role" of the press as a "public watchdog").

138. Orla Lynskey observes that the CJEU in Google Spain "appears to assume that when the rights to privacy and data protection are at stake the right to freedom of expression extends only to 'public interest' information - as opposed to information in which the public may have an interest." Lynskey, supra note 83, at 531. 
within that structure. That is why both the Directive and the GDPR provide categorical derogations for journalistic purposes insofar as is necessary to protect freedom of expression, regardless of the contents of any particular newspaper article. ${ }^{139}$

Government regulation of the press triggers concerns for freedom of expression in Europe and in the United States because everyone understands that the press is a structural precondition for the public discourse necessary for self-government. The press is indispensable for the capacity "of the members of an organized society, united for their common good, to impart and acquire information about their common interests." 140 The CJEU fails to distinguish between the public interest in a particular article in the press, and the public interest in the press itself, which is a structure of communication that creates the public sphere within which public opinion can be formed.

The most important question raised by Google Spain, therefore, is whether Google has become, like the modern newspaper, an essential component of the communicative infrastructure necessary to sustain the public sphere. If it has, the CJEU's reference to Google's "economic interest" is misleading and gratuitous. It is commonly acknowledged that "the newspaper is a private enterprise. Its object is to make money for its owner." 141 But the public interest in the press is not less because the press is run for profit. ${ }^{142}$ The CJEU has itself recognized that the Directive's exemption for the processing of data for journalistic purposes does not depend upon whether the press is a commercial enterprise. ${ }^{143}$ If Google were indeed properly deemed

139. GDPR, supra note 17, art. 85; Dircctive, supra note 5, art. 9.

140. Grosjean v. Am. Press Co., 297 U.S. 233, 243 (1936).

141. Charles Dudley Warner, The American Newspaper, in 14 J. SoC. SCI. 52, 52 (1881).

142. "That books, newspapers, and magazines are published and sold for profit does not prevent them from being a form of expression whose liberty is safeguarded by the First Amendment." Joseph Burstyn, Inc. v. Wilson, 343 U.S. 495, 501-02 (1952).

143. In Case C-73/07, Tietosuojavaltuutettu v. Satakunnan Markkinapörssi Oy \& Satamedia Oy, 2008 ECR I-09831, the CJEU held that Article 9 of the Directive exempts from regulation the publication in a newspaper and the commercial sale in the form of CD-ROM discs of publicly available tax information about named persons when a national court holds that such communication serves journalistic purposes. It concluded that

the fact that the publication of data within the public domain is done for profit-making purposes does not, prima facie, preclude such publication being considered as an activity undertaken 'solely for journalistic purposes'... [E]very undertaking will seek to generate a profit from its activities. A degree of commercial success may even be essential to professional journalistic activity.... [T] he medium which is used to transmit the processed data, whether it be classic in nature, such as paper or radio waves, or electronic, such as the internet, is not determinative as to whether an activity is undertaken 'solely for journalistic purposes'. 
comparable to a newspaper, its "economic interest" should be irrelevant.

Google Spain holds, however, that because Internet search engines are not journalistic enterprises, they are not exempt from the fair information practices of the Directive. It states that-although "the processing by the publisher of a web page consisting in the publication of information relating to an individual may, in some circumstances, be carried out 'solely for journalistic purposes' and thus benefit, by virtue of Article 9 of Directive 95/46, from derogations from the requirements laid down by the directive"-the derogation "does not appear to" apply to "the processing carried out by the operator of a search engine." 144

To evaluate this holding, we must explore the relationship between the links provided by contemporary Internet search engines and the news offered by traditional newspapers. In the next Part of this Article, I examine the rise of the contemporary American newspaper in an effort to articulate why American law came to regard news as essential to the maintenance of public discourse. My hope is to enable us more clearly to determine whether Google should be invested with the same kind of public interest that we accord to the press.

The argument I pursue is a structural one: The press serves the public interest by sustaining public discourse because it disseminates news, which is to say because it publishes texts that both respond to and incite general public interest. The public interest of Google ought to be evaluated according to the same criteria.

\section{THE RISE OF A "NEWSPAPERIZED WORLD"145}

In Google Spain, the CJEU gave Google the back of its hand, brushing it off as nothing more than a commercial entity bent on maximizing profits. Although it recognized a public interest in receiving information that might override the privacy protections of the Directive, the CJEU failed to theorize what that interest might be. In this Part, I recount the rise of the contemporary American newspaper in an effort to illuminate the nature of the public interest that modern democracies attribute to the press. This interest is not merely in the receipt of particular kinds of information, as the CJEU

\footnotetext{
Id. at paras. 59-60.

144. Google Spain, supra note 12, para. 85 .

145. Henry James, The Notebooks of Henry James 84-85 (Nov. 17, 1887) (F.O. Matthiessen \& Kenneth B. Murdock eds., Phoenix ed. 1981) (1947).
} 
seems to have thought, but in maintaining the discursive preconditions for a "public."

If democracy is "the organized sway of public opinion," 146 democracy must presuppose the existence of a "public" capable of possessing an "opinion."147 A "public" is a specific kind of social organization that arises within the "public sphere" 148 by uniting strangers through common exposure to common texts. A public is "not localized in space and time." 149 It is defined "by the fact that its members ha[ve] access to the kind of publicness made possible by the printed word." 150 A public emerges from "the circulation of texts among strangers who become, by virtue of their reflexively circulating discourse, a social entity." 151

The literary critic Michael Warner observes that

[o]ne of the most striking features of publics, in the modern public sphere, is that they can in some contexts acquire agency... They are said to rise up, to speak, to reject false promises, to demand answers, to change sovereigns, to support troops, to give mandates for change, to be satisfied, to scrutinize public conduct, to take role models, to deride counterfeits. ${ }^{152}$

The CJEU itself in Google Spain engages in precisely this kind of personification when it speaks of a "preponderant interest of the general public in having . . . access to" particular kinds of information. ${ }^{153}$ It is through their identification as a "public" that the people of a country exercise the prerogatives of democracy. That is why the sociologist Michael Schudson characterizes the "public" as "the fiction that brings self-government to life." 154 The public need not be especially rational, as some like Habermas have presupposed. ${ }^{155}$

146. Charles Horton CoOley, Social Organization: A Study of the Larger MIND 118 (1909) (emphasis added).

147. See Michael Schudson, Why Conversation Is Not the Soul of Democracy, 14 CRITICAL STUD. MASS COMM. 297, 304-05 (1997).

148. See Jürgen habermas, The Structural transformation of the Public SPHERE: AN INQUIRY INTO A CATEGORY OF BOURGEOIS SOCIETY 181 (Thomas Burger trans., The MIT Press 1989) (1962); Charles TAYlor, PhilosophiCAl ARguments 257-87 (1995).

149. JOHN B. THOMPSON, THE MEDIA AND MODERNITY: A SOCIAL THEORY OF THE MEDIA 126 (1995).

150. Id. at $126-27$.

151. Michael Warner, Publics AND Counterpublics 11-12 (2002).

152. Id. at $122-23$.

153. Google Spain, supra note 12, para. 99.

154. Michael Schudson, The POWER OF News 32 (1995).

155. HABERMAS, supra note 148, passim; see Antoine Lilti, The Invention of 
But it must exist in the imagination of a population.

The pioneering French sociologist Gabriel Tarde, who was one of the first to theorize the nature of the public, observed that the people who comprise publics do not meet in the public street or in the public square, but instead "are all sitting in their own homes scattered over a vast territory, reading the same newspaper." ${ }^{156}$ Although "[t]he public could begin to arise only after the first great development in the invention of printing, in the sixteenth century .... [t] he true advent ... of the public" occurred with the invention of journalism in the eighteenth century. ${ }^{157}$ For the last several centuries, the press has been "the public sphere's preeminent institution." 158 That is why Thomas Jefferson observed in 1787 that

[t] he basis of our governments being the opinion of the people, the very first object should be to keep that right; and were it left to me to decide whether we should have a government without newspapers, or newspapers without a government, I should not hesitate a moment to prefer the latter. ${ }^{159}$

Celebrity: 1750-1850, at 9 (Lynn Jeffress trans., Polity Press 2017) (2015) ("[The public is] an entire group of anonymous readers who all read the same books and, more and more in the eighteenth century, the same newspapers. The public is defined not by rational arguments, but by sharing the same curiosity ....").

156. Gabriel TARDE, On COMMUNiCATION AND SOCIAL INFLUENCE 278 (Terry N. Clark ed., 1969).

157. Id. at 279-80. The story of the rise of newspapers is nicely told in ANDREW PETTEGREE, THE INVENTION OF NEWS: How THE WORLd CAME TO KNOW ABOUT ITSELF (2014).

158. HABERMAS, supra note 148 , at 181.

159. Thomas Jefferson to Edward Carrington, January 16, 1787, in 11 THE PAPERS OF Thomas JefFerson 48, 49 (Julian P. Boyd ed., 1955). James Madison reached precisely the same conclusion. He observed that "[p]ublic opinion sets bounds to every government, and is the real sovereign in every free one." James Madison, Public Opinion, NAT'L GAZETTE, Dec. 19, 1791, at 59 . He then observed that the circulation of newspapers was essential to the formation of public opinion:

The larger a country, the less easy for its real opinion to be ascertained, and the less difficult to be counterfeited; when ascertained or presumed, the more respectable it is in the eyes of individuals. - This is favorable to the authority of government. For the same reason, the more extensive a country, the more insignificant is each individual in his own eyes. - This may be unfavorable to liberty.

Whatever facilitates a general intercourse of sentiments, as good roads, domestic commerce, a free press, and particularly a circulation of newspapers through the entire body of the people, and Representatives going from and returning among every part of them, is equivalent to a contraction of territorial limits, and is favorable to liberty, where these may be too extensive.

Id. The Founders understood the implications of Madison's analysis, enacting in the Postal Act of 1792 favored mailing rates for newspapers. See RiCHARD R. JOHN, SPREADING THE NEWS: THE AMERICAN POSTAL SySTEM FRoM FRANKLiN TO MORSE $28-42$ (1995); id. at 56 ("With the passage of the Post Office Act of 1792 ... the public sphere became disembodied, that is, it became 
Newspapers offered a continual and current stream of information and opinion that provoked widespread interest and so created an everexpanding field of shared textuality. Only a newspaper, Alexis de Tocqueville wrote, "can succeed in putting the same thought in a thousand minds at the same instant." "160 "[T]he newspaper will create an immense, abstract, and sovereign crowd which it will name opinion." "161 The social psychologist Charles Cooley put it well in 1909:

In politics communication makes possible public opinion, which, when organized, is democracy. The whole growth of this . . . is immediately dependent upon the telegraph, the newspaper and the fast mail, for there can be no popular mind upon questions of the day, over wide areas, except as the people are promptly informed of such questions and are enabled to exchange views regarding them. ${ }^{162}$

Two centuries ago, the vast majority of newspapers in the United States were "organs of political parties." 163 The "party press . . came to be what we know as a journal of opinion," "164 in which the editor and the opinion page were most prominently featured. But in the $1830 \mathrm{~s}$ "a new breed of urban paper, the so called 'penny press,' discovered that one could make money by printing local news as well as national political news, by hawking newspapers on the street and . . . by lowering the price of a copy from 6 cents to a penny or two." 165 A fierce competition developed for readers and advertisers. This "marked a revolution in American journalism," which "led to the triumph of 'news' over the editorial and 'facts' over opinion, a change which was shaped by the expansion of democracy and the market."166

The penny press expanded newspaper circulation. It did so by inventing "the modern concept of "news":

For the first time the American newspaper made it a regular practice to print political news, not just foreign but domestic, and not just

identified with a process that existed not in a particular place but rather in the imagination of millions of people, most of whom would never meet face-to-face.").

160. AleXis DE TOCQueville, DemOCRACY IN AMERICA 906 (Eduardo Nolla ed., James T. Schleifer trans., 2012) (1840).

161. TARDE, supra note 156 , at 318.

162. COOLEY, supra note 146 , at 85 .

163. Michael Schudson, Why Democracies Need an Unlovable Press 43 (2008).

164. Robert E. Park, The Natural History of the Newspaper, in ROBERT E. PARK, ERNEST W.

BURGESS \& RODERICK D. MCKENZIE, THE CITY 80, 88 (Midway reprint 1984) (1925).

165. SCHUDSON, supra note 163 , al 43.

166. Michael SChudson, Discovering the News: A Social History of American NEWSPAPERS 14 (1978). 
national but local; for the first time it printed reports from the police, from the courts, from the streets, and from private households. One might say that, for the first time, the newspaper reflected not just commerce or politics but social life. To be more precise, in the $1830 \mathrm{~s}$ the newspapers began to reflect, not the affairs of an elite in a small trading society, but the activities of an increasingly varied, urban, and middle-class society of trade, transportation, and manufacturing. ${ }^{167}$

Newspapers hired reporters who fanned out across the urban environment and inculcated a "democratic attitude toward the happenings of the world: any event, no matter how apparently trivial, might qualify for print in a newspaper." 168 The collapse of earlier structures of hierarchy and deference, ${ }^{169}$ celebrated in the boisterous egalitarian American democracy described by de Tocqueville, found apt expression in the expansion of the concept of news, which reached out to include whatever might be of interest to the scrambling interests of the newly liberated middling classes.

Newspapers began to compete in the "commodity" of "news, i.e. information respecting recent events in which the public takes an interest, or in which an interest can be excited." 170 The penny press assigned reporters "to the police, the courts, the commercial district, the churches, high society, and sports. The penny papers made the 'human interest story' not only an important part of daily journalism but its most characteristic feature." ${ }^{\prime 17}$ Power within newspapers began to shift from editors and the editorial page to "the news and the reporter." $" 172$

167. Id. at $22-23$.

168. Id. at 28 .

169. Robert H. Wiebe, Self-Rule: A Cultural History of American Democracy 17-18, 38-39 (1995).

170. James Parton, The New York Herald, 102 N. AM. REV. 373, 418 (1866).

171. SCHUDSON, supra note 166, at 27. George Herbert Mead observed that "an intelligent newspaper management . . . can never get far away from the form of the news" which the "reveries" of its readers "demand." George H. Mead, The Nature of the Aesthetic Experience, 36 INT'L J. ETHICS 382, 390 (1926). Mead observed that in "certain limited fields, such as the stock market ... the truth value of news holds absolutely. Outside of these fields, and the farther one gets away from them, the more does the enjoyability, the consummatory value, of the news bulk in value on the market. The reporter is generally sent out to get a story, not the facts." Id.

172. Park, supra note 164, at 283. As biographer James Parton put it:

The word newspaper is the exact and complete description of the thing which the true journalist aims to produce. The news is his work; editorials are his play. The news is the point of rivalry; it is that for which nineteen twentieths of the people buy newspapers; it is that which constitutes the power and value of the daily press; it is that which determines the rank of every newspaper in every free country.

Parton, supra note 170, at 376. 
The devotion of the penny press to the news was denounced as sensationalism. ${ }^{173}$ It was considered unseemly and improper to expose the criminal underbelly of urban life or the balls and parties of high society. At root, these denunciations were "a cover for class conflict."174 Old elites resented a communicative medium designed to satisfy the curiosity of upstart plebeians. This conflict intensified as the nineteenth century progressed, and as immigrants, both domestic and foreign, poured into American cities. These new residents were mystified by the spectacle, by the language, by the complex patterns of the urban scene.

To increase circulation and hence advertising revenue, newspapers responded by creating photographs and illustrations, larger and darker headlines, abbreviated news stories, ${ }^{175}$ an everwidening variety of topics, comic strips, the potpourri that makes up the Sunday paper, and so on. ${ }^{176}$ In the process they created a mass audience. ${ }^{177}$ On the sidewalk, one could observe a "torrent of workingmen pouring down town, many of them reading as they go, and most of them provided with a newspaper for dinner-time, not less as a matter of course than the tin kettle"; on the street was a "long line of hackney-coaches on a stand, nearly every driver sitting on his box reading his paper." 178

From a democratic point of view, the commercial success of newspapers was all to the good. It swept up the masses into the reading public and produced a sense of belonging that cannot be overemphasized. "The newspaper is that which connects each individual with the general life of mankind, and makes him part and

173. In the words of Michael Schudson:

This accusation was substantiated less by the way the penny papers treated the news (there were no sensational photographs, of course, no cartoons or drawings, no large headlines) than by the fact that the penny papers would print 'news' - as we understand it - at all. It was common for penny papers, covering a murder trial, to take a verbatim transcript of the trial and spread it across most, or all, of the front page. What the sixpenny press decried as immoral was that a murder trial should be reported at all.

SCHUDSON, supra note 166, at 23.

174. Id. at 118-19.

175. Newspapers were meant to be read "in an age of hurry ... . The newspaper is not read in the secrecy and silence of the closet as is the book. It is picked up at a railway station, hurried over in a railway carriage, dropped incontinently when read." T.P. O'Connor, The New Journalism, in 1 THE NEW REVIEW 423, 434 (Archibald Grove ed., 1889).

176. For a study of the content of newspapers at this time, see Delos F. Wilcox, The American Newspaper: A Study in Social Psychology, 16 AnNals AM. ACAD. POL. SOC. SCI. 56 (1900).

177. Samantha Barbas, Saving Privacy from History, 61 DEPAUL L. REV. 973, 980 (2012).

178. Parton, supra note 170 , at 377. 
parcel of the whole; so that we can almost say, that those who neither read newspapers nor converse with people who do read them are not members of the human family ...." 179 There was a "craving" for news "and lots of it." 180 On days in New York without newspapers (July 5 and January 2),

[a] shadow appears to rest on the world ....We are separated from our brethren, cut off, lost, alone; vague apprehensions of evil creep over the mind. We feel, in some degree, as husbands feel who, far from wife and children, say to themselves, shuddering, "What things may have happened, and I not know it!" Nothing quite dispels the gloom until the Evening Post - how eagerly seized - assures us that nothing very particular has happened since our last. ${ }^{181}$

Reading newspapers brought the masses into the circle of conversation that produced public opinion ${ }^{182}$ and thereby constructed public opinion on a broader and more democratic basis. In turn newspapers expanded their circulation by reshaping the commodity of news to meet the interests of the masses. Newspapermen justified their expansion by claiming to supply "what the public wanted-witness their growing sales." 183 By the end of the nineteenth century,

179. Id.

180. Richard Watson Gilder, The Newspaper, the Magazine, and the Public: As Interviewed by Clifton Johnson, OurLooK, Feb. 4, 1899, at 317, 320.

181. Parton, supra note 170, at 377. The feelings of New York residents were studied when New York delivery-men went on strike for two weeks in July 1945, and analogous apprehensions of "feeling completely lost" without newspapers emerged. See Bernard Berelson, What "Missing the Newspaper" Means, in COMmuniCATIONS RESEARCH 1948-1949, at 111, 111-29 (Paul F. Lazarsfeld \& Frank N. Stanton eds., 1949).

182. Warner, supra note 141, at 56-57 ("Nothing else ever invented has the public attention as the newspaper has, or is an influence so constant and universal. It is this large opportunity that has given the impression that the newspaper is a public rather than a private enterprise.").

183. Opinion-Moulding, NATION, Aug. 12, 1869, in 9 The NATION 121, 127 (1872). The Commission on Freedom of the Press analogously described the industry and its growth:

Information and discussion regarding public affairs, carried as a rider on the omnibus of mass communication . . . must be shaped so that they will pay their own way by attracting the maximum audience.

....

Hence the word "news" has come to mean something different from important new information. When a journalist says that a certain event is news, he does not mean that it is important in itself. Often it is; but about as often it is not. The journalist means by news something that has happened within the last few hours which will attract the interest of the customers. The criteria of interest are recency or firstness, proximity, combat, human interest, and novelty.

$\ldots$

To attract the maximum audience, the press emphasizes the exceptional rather than the representative, the sensational rather than the significant.

The Commission on FreEdom of THE PRESS, A FREE AND RESPONSIBLE PRESS 54-55 (1947). 
newspapers were defining news as "everything that occurs, everything ... which is of sufficient importance to arrest and absorb the attention of the public or of any considerable part." 184 Successful editors were said to possess the "sixth sense" to discern "what is most likely to interest the public . . . to tell the day before or at midnight what the world will be talking about in the morning." 185 The news became "what Charles A. Dana described it to be, 'something that will make people talk." "186 News promoted these forms of social solidarity because, in the words of social theorist George Herbert Mead, it allowed the reader to interpret "his experience as the shared experience of the community of which he feels himself to be a part." 187

Packaged "in the form of small, independent communications that can be easily and rapidly comprehended," news began to perform

the same functions for the public that perception does for the individual man; that is to say, it does not so much inform as orient the public, giving each and all notice as to what is going on. It does this without any effort of the reporter to interpret the events he reports, except in so far as to make them comprehensible and interesting. ${ }^{188}$

Because "[i]t is upon the interpretation of present events, i.e., news, that public opinion rests," 189 it can be said that "[t]he extent to which

184. Charles A. Dana, The ARt of NewSPaPer Making 12 (1895). Dana continued

There is a great disposition in some quarters to say that the newspapers ought to limit the amount of news that they print; that certain kinds of news ought not to be published. I do not know how that is. I am not prepared to maintain any abstract proposition in that line; but I have always felt that whatever the Divine Providence permitted to occur I was not too proud to report.

Id. Compare this to the contemporaneous credo of the literary realist set forth by William Dean Howells: "In life he finds nothing insignificant; all tells for destiny and character; nothing that God has made is contemptible. He cannot look upon human life and declare this thing or that thing unworthy of notice ...."W.D. HOWELLS, CRITICISM AND FICTION AND OTHER ESSAYS 15 (Clara Marburg Kirk \& Rudolf Kirk eds., 1959).

185. Warner, supra note 141, at 56.

186. Robert E. Park, News as a Form of Knowledge: A Chapter in the Sociology of Knowledge, 45 AM. J. SOC. 669, 678-79 (1940).

187. Mead, supra note 171 , at 390 .

188. Park, supra note 186 , at 677 . Park continued:

A news item, as every newspaperman knows, is read in inverse ratio to its length. The ordinary reader will read a column and a half of two- or three-line items about men and things in the home town before he will read a column article, no matter how advertised in the headlines, unless it turns out to be not merely news but a story, i.e., something that has what is called technically "human interest."

Id.

189. Id. Describing the formation of public opinion, the sociologist Carroll Clark noted: [T]he human-interest and sensational material on which is centered so largely the public's attention presents exactly those "extraordinary occurrences" that set in motion 
news circulates within a ... political society, determines the extent to which the members of such a society may be said to participate ... in its political acts." 190 By 1920, Walter Lippmann could write with assurance that "democracy is unworkable" and "[p]ublic opinion is blockaded ... if there is no steady supply of trustworthy and relevant news." 191 Those excluded from the news could not fully take part in the formation "of that public opinion which is the final source of government in a democratic state." 192

Many American elites, however, found the mass appeal of newspapers degrading and vulgar. Charles Eliot Norton, the aristocratic president of Harvard, sniffed that popular newspapers were "largely addressed to a horde of readers who seek in them not only the news of the day, but the gratification of a vicious taste for strong sensations; who enjoy the coarse stimulants of personalities and scandal, and have no appetite for any sort of proper intellectual nourishment." ${ }^{193}$ Condé Benoist Pallen, the editor of Catholic World, recoiled from news columns as "spiced and fetid with all the filth of a degraded morale and an infamous taste, designed to cater to the morbid imagination of the masses," and serving up "the record of the murders, rapes, hangings, poisonings, incendiarisms, suicides, divorces, thefts, burglaries, incests, lusts, and all other abominations perpetrated by perverted humanity." 194 The Reverend George T. Rider condemned

the processes of social opinion and provide data for the formation of moral judgments. The communications of the general public, then, turn out to be largely concerned with getting a basis for a larger common understanding, with funding diverse experiences into intelligible wholes,-in short, with establishing a wider consensus and a moral order.

Carroll D. Clark, The Concept of the Public, 13 Sw. SoC. SCI. Q. 311, 319 (1933).

190. Park, supra note 186 , at 677 . News is "the stuff which makes political action, as distinguished from other forms of collective behavior, possible." Id at 678. Hence "[a] man without a newspaper is half-clad, and imperfectly furnished for the battle of life." W.T. Stead, The Future of Journalism, 50 CONTEMP. REV. 663, 663 (1886).

191. WAlter LippmanN, LiBerty AND THE News 13-14 (Transaction Publishers 1995) (1920). He continued:

It may be bad to suppress a particular opinion, but the really deadly thing is to suppress the news. ... When freedom of opinion is revealed as freedom of error, illusion, and misinterpretation, it is virtually impossible to stir up much interest in its behalf. It is the thinnest of all abstractions and an over-refinement of mere intellectualism. But people, wide circles of people, are aroused when their curiosity is baulked. The desire to know ... is a really powerful motive, and it is that motive that can best be enlisted in the cause of freedom.

Id. at 58-59.

192. Masses Publ'g Co. v. Patten, 244 F. 535, 540 (S.D.N.Y.), rev'd, 246 F. 24 (2d Cir. 1917).

193. Charles Eliot Norton, The Intellectual Life of America, 6 NEW PRINCETON REV. 312, 318 (1888).

194. Condé Benoist Pallen, Newspaperism, 38 LipPinCOTT's MONTHLY MAGAZINE 470, 473 
the Sunday paper as "avowedly and offensively secular," a "direct and deliberate bid for the popular eye and ear in competition with the pulpit." ${ }^{195}$

No one more brilliantly expressed the shock and horror of newspapers than Henry James, who was appalled at the very thought of women reading newspapers at breakfast, wearing that "newspaper face, with its mere monstrosity and deformity of feature and the vast open mouth, adjusted as to the chatter of Bedlam, that flings the floodgates of vulgarity further back than anywhere else on earth." "What would be the natural effect," James, asked, "of all the unashamed grossness and blatancy and illiteracy and impudence, what that of the perpetual vision of head-lines elongated as to the scream of the locomotive[?]"197

We might dismiss such complaints as the mere grumblings of a displaced elite, were it not for the fact that the triumph of news caused profound changes in American social and political life that we associate with the arrival of modernity, as James's metaphor of the locomotive

(1886) (emphasis in original). Pallen feared that readers would become acculturated to crime and moral iniquity:

No vicious picture can be moral; and the result of this constant mirroring of vice to the public mind is so to habituate and familiarize it with crime and sin that the horror and repugnance to which they at first naturally give rise degenerate into an endurance, then a pity, and at last, by insensible degrees, into that diseased condition of the imagination which does not hesitate to embrace the monster. We hear so much of murder, rape, incest, burglary, and the entire catalogue of human atrocities, that we begin to regard them as matters of course.

Id. at 474 .

195. George T. Rider, The Pretensions of Journalism, 135 N. AM. REV. 471, 479 (1882).

According to Rider, the Sunday paper

creeps into houses before breakfast, and spins well its web of thrall and glamour before morning service. ... Theaters and drinking-saloons, with most places of traffic and industry, are closed on Sunday. It remains for journalism alone to resist the unanimous conclusions of Christian people and profane the Lord's day in its greed of gain.

Id. at 480 .

On the deep tension between the press and traditional forms of authority, see V.S. Yarros, The Press and Public Opinion, 5 AM. J. Soc. 372, 375 (1899). As Yarros notes:

Authority is something totally unknown to the newspaper. The editorial 'we' is above all. The editor is glad to have the support of authority, but he is not daunted or disturbed at finding recognized authority against his position. The mature opinions of scholars and experts he treats with a flippancy and contempt which the slightest degree of responsibility would render impossible. But the editor is irresponsible. The judicious and competent few may laugh at his ignorance and presumption, but the cheap applause of the many who mistake smartness for wit and loud assertion for knowledge affords abundant compensation.

Id. at 375 .

196. Henry James, The Manners of American Women, HARPER's BAZAR 453, 465 (1907).

197. Id. 
whistle unerringly suggests. Journalism and the news became "the sense-making practice of modernity . . . a product and promotor of modern life ... unknown in traditional societies." ${ }^{198}$ In the context of Google Spain, it is important to stress four ways in which journalism helped to produce the distinctively modern public sphere that we now take for granted.

First, the shift from journals of opinion to newspapers undermined the influence of cultural elites, who had previously exerted great cultural influence through their control of editorial pages. As the prestige of editorials in American newspapers "declined"199 - far more so than in the European press ${ }^{200}$-it became clear that "editorials neither make nor mar a daily paper, that they do not much influence the public mind, nor change many votes, and that the power and success of a newspaper depend wholly and absolutely upon its success in getting and its skill in exhibiting the news." 201

Insofar as newspapers were significant players in "shaping the social and political world," 202 this shift in authority from editorials to news undercut elite control over the interpretation of current events.

198. John Hartley, Popular Reality: Journalism, MODERnity, POPULAR Culture 33 (1996).

199. "The news-gathering function, which the American press was the first to bring into prominence, has become the most important one, and the critical function has relatively declined." E.L. Godkin, Newspapers Here and Abroad, 150 N. AM. REV. 197, 197-98 (1890); see Gilder, supra note 180, at 318 ("The editorial opinion on political movements as expressed in the papers doesn't have the weight with readers it once did. Journalism's greatest power to-day lies in the dissemination of fact rather than in the advocacy of policy ....").

200. Godkin, supra note 199 , at 198 . Commenting on the difference between American and European newspapers, Godkin states,

[a]s a general rule, the American publisher devoted himself to news, and the European to criticism or comment. The former found a much larger public which wanted news, and cared comparatively little for criticism or literary form; the latter found his account in catering for a smaller public, and one more exacting in the matter of taste.

Id. at 198 . He also adds that

[t]he stories which Parisian journalists tell each other in their cafés are not of their prowess as reporters, but of the sensations they have made and the increase in circulation they have achieved by some sort of editorial comment or critique; the American passion for and glory in 'beats' - meaning superiority over rivals in getting hold of news - they do not understand, or thoroughly despise.

Id. at 198, 200; see DANA, supra note 184, at 11.

201. Parton, supra note 170 , at 376 . "The editorial page, once the forum where public opinion was expressed,-- where the voice of the people was ably crystallized into forcible phrases, - has become a little-read and insignificant part of the average paper." John Henderson Garnsey, The Demand for Sensational Journals, 18 ARENA 681, 682 (1897).

202. Godkin, supra note 199 , at 202. Godkin went so far as to say that newspapers "are, and have been for the last half-century, exerting more influence on the popular mind and the popular morals than either the pulpit or the book press has exerted in five hundred years." $I d$. 
Editorials are "for the intellectuals," sociologist Robert E. Park wrote in 1941, but "[t]he news . . is for the great mass of mankind."

[P]ublic opinion formed on the basis of the news represents the interpretation of events which each individual makes for himself in accordance with his individual interests, prejudices, and predilections, qualified by the interpretation which other individuals with whom he has discussed the matter have made of the same events....

[T] he effect of news on public opinion is just the opposite of that of the editorial, which seeks to focus attention on a principle or program for political action. As a matter of fact, news tends to disintegrate political principles, doctrines, and dogmas that have been necessarily formulated out of the experience of an earlier time.... [W] hen great and rapid changes are taking place, it is difficult for editorial programs and political policies to keep pace with events. In such periods it is the interpretation which the great mass of the readers finally agrees to put upon events that makes public opinion. ${ }^{203}$

This shift was essentially democratic, because it allowed public opinion to be influenced from the bottom up, from the innumerable conversations provoked by the innumerable readers of the day's news. "The efficient mechanics of the modern press make it possible for sixty million people to read of any important event at the same moment and in the same amazing detail," observed the great New York Times editor Charles Merz in $1928 .{ }^{204}$ The natural corollary was that "[w]hen it comes to focusing the attention of the whole nation searchingly upon a single subject, and giving it a single set of facts on which to test its moral values, it is doubtful whether anything really unifies the country like its murders." $" 205$

By presenting the news in disjunct and parataxic fashion, newspapers effectively "trained their readers in the apprehension of

203. Robert E. Park, News and the Power of the Press, 47 AM. J. SoC. 1, 10-11 (1941). Of course newspapers quickly learned the art of seeking to influence public opinion by manipulating their presentation of the news:

The editor does not expect to form public opinion so much by arguments and appeals as by the news he presents, and his manner of presenting it; by the iteration of an idea until it becomes familiar; by the reading matter selected, and by the quotations of opinions as news, and not professedly to influence the reader. And this influence is all the more potent because it is indirect and not perceived by the reader.

Warner, supra note 141, at 66; see Opinion-Moulding, supra note 183, at 126 ("In fact, though they make no comments whatever, they are able, by their mode of reporting the events of the day, to mould public opinion completely.").

204. Charles Merz, The Great American Band Wagon 71 (1928).

205. Id. 
detached, independent, reified, decontextualized 'articles'" that normalized "the apparently irreducible fragmentation of daily experience." 206 This fragmentation embodied the disintegration of traditional cultural narratives and unsettled old elites. They experienced journalism as "the parent of anarchy, destructive of free institutions and of social order" because productive of a "readiness to question and to resist the exercise of authority" by those entitled to lead due to their "superior character, intelligence, and education."207 From the perspective of those accustomed to controlling the standards and principles of society, newspapers missed "the really serious happenings" and instead concentrated on "sensations, crimes, scandals or gossip" designed "to amuse, entertain and excite" the great mass of readers, and so lead the public "not only into the regions of disjointed thinking but into absolutely wrong thinking." 208

Second, the triumph of news created a public sphere of enormous and irresistible social significance and appeal. To be cut off from the circulation of news was to be thrown outside of current events; it was to be excommunicated from the formation of common sentiments and attitudes and the shared interpretation of common experience. Hence the startling emergence of "an inordinate hunger and thirst for" news, ${ }^{209}$ which was in fact a craving for the texts of newspapers. In fact the enticement of public texts began to compete with the pull of ordinary embodied life. Consider, for example, Charles Cooley's comment on the "strange practice, .... when you think of it, that a man should sit down to his breakfast table and, instead of conversing with his wife, and children, hold before his face a sort of screen on which is inscribed a world-wide gossip!"210

As attention to the public sphere grew, so did the demand that public texts offer vivid, vicarious experience. The lure of the public sphere was enhanced by the spectacular growth of visual representations. By the end of the nineteenth century, there was a large and insatiable demand for illustrations and photographs, which were felt to provide a more accessible and immediate access to the events and persons described in the news. It was believed, for example, that

206. Richard Terdiman, Discourse/COUNTER-Discourse: THE THEORY AND PRACTICE OF SYMBolic ResistanCE IN NINETEENTH-CENTURy FranCE 122, 125 (1985).

207. Charles Eliot Norton, Some Aspects of Civilization in America, 20 FORUM 641, 647, 650 (1896).

208. Jno. Gilmer Speed, Do Newspapers Now Give the News?, 15 FORUM 705, 709-11 (1893).

209. Rider, supra note 195, at 478.

210. COOLEY, supra note 146 , at 83 . 
"[t]he physiognomy of a candidate for office is an important object for public scrutiny as it betokens character. ..."211 The pressure for new and expanded forms of visibility importantly modified existing norms of reticence. ${ }^{212}$ Earlier in the century the use of unauthorized portraits would have been condemned as "invasions of the right of privacy." 213 But by the end of the nineteenth century unauthorized visual representations of public figures became acceptable. ${ }^{214}$

When a bill was introduced into the New York legislature to make it a crime "to print or publish in any newspaper, periodical, pamphlet or book 'any portrait or alleged portrait of any person or individual living in this State without have first obtained his or her written consent," the pro-privacy New York Times applauded the intent to suppress "the outrageous invasion of private rights which has become so common in publishing portraits of persons who have no relation to

211. Wilbur Larremore, The Law of Privacy, 12 COLuM. L. REV. 694, 701 (1912).

212. For a brilliant study of this topic, see generally ROCHELLE GURSTEIN, THE REPEAL OF RETICENCE: A History OF AMERICA'S CULTURAL AND LEGAL STRUGGles OVER FreE SPEECH, OBSCENITY, SEXUAL LIBERATION, AND MODERN ART (1996). "[T] he dominance of the visual image in contemporary culture and the technology that makes it possible to capture and, in an instant, universally disseminate a picture or sound allows us, and leads us to expect, to see and hear what our great-grandparents could have known only through written description." Shulman v. Grp. W Prods., Inc., 955 P.2d 469, 473-74 (Cal. 1998).

213. John Gilmer Speed, The Right of Privacy, 163 N. AM. REV. 64, 73 (1896). Even now "[t]he image, a constitutive element of the person, occupies a privileged position in the protection of privacy in French law in reference to the 'moral interests of the person.' . . French law mandates explicit consent of a person for any publication of her image: the publication of pictures taken without a person's knowing is held to be a violation of 'right upon one's image,' whether she is in a public or in a private place and whether the person is a public figure or not." Ioanna Tourkochoriti, Speech, Privacy and Dignity in France and in the U.S.A.: A Comparative Analysis, 38 LOY. L.A. INT'L \& COMP. L. REV. 217, 244 (2016). On the changes wrought by "the visual culture of celebrity," see LILTI, supra note 155, at 261-66.

214. According to W. Archibald McClean:

There is a distinction, however, between a public and private character. A private individual should be protected against the publication of any portraiture of himself, but where an individual becomes a public character, the case is different. A statesman, author, artist, or inventor who asks for and desires public recognition, may be said to have surrendered his right to the public. When anyone obtains a picture or photograph of such a person and there is no breach of contract or violation of confidence in the method by which it was obtained he has the right to reproduce it, whether in newspaper, magazine or book. It would be extending this right of protection too far to say that the general public can be prohibited from knowing the personal appearance of great public characters. Such characters may be said of their own volition to have dedicated to the public, the right of any fair portraiture of themselves.

The Right of Privacy, 15 GREEN BAG 494, 495 (1903). In Great Britain "Queen Victoria inaugurated an era in which images of leaders were widely distributed, thanks to numerous kinds of media, aimed at the governed. Therefore, the image of incarnated power became both more banal, because it was an object of cheap consummation, and more powerful, capable of profoundly affecting feelings of loyalty or repudiation." LILTI, supra note 155, at 249. 
the public that makes them proper subjects of representation in the public prints." 215 But the Times nevertheless criticized the statute in part because it failed to penalize representations of private persons in print. ${ }^{216}$ "The invasion of privacy may be perpetrated quite as offensively in language as in portraiture," the Times asserted. "To describe the looks, peculiarities, manners, dress, and conduct of persons in their private relations ... and to parade these details in print without the consent and against the wishes of such persons, is just as offensive as printing their portraits or alleged portraits, and may be made much more so, since the pictorial facility of the pen is greater than that of the pencil.".217

The objection well illustrates the continuity of graphic and linguistic forms of representation. ${ }^{218}$ Both are texts that circulate in the public sphere. The Times conceded in its discussion of the bill that it was appropriate to publish the portraits of public figures because such illustrations were responsive to the expectations of readers that the public sphere, properly defined, reproduce an immediacy and intimacy

215. The Protection of Privacy, N.Y. TIMEs (Mar. 14, 1897), http:/query.nytimes.com/mem/ archive-free/pdf?res=9F04E4D61F31E132A25757C1A9659C94669ED7CF [https://perma.cc/88 TP-9U76].

216. The Times also criticized the proposed New York statute because it failed to distinguish between private persons and truly public persons, whose status made them a fit object of portraiture. Id. For examples of the Times affirming the rights of private persons to prevent graphic forms of representation, see The Right to Privacy, N.Y. TIMES, June 23, 1891, p. 4; The Right to Privacy, N.Y. Times, Nov. 28, 1895, p. 4; The Right to Privacy, N.Y. Times, Apr. 12, 1903, p. 6 (approving the horsewhipping by socialite Reggie Vanderbilt "of a 'yellow gent' with a camera who, he imagined, had placed himself at the side of the road which MR. REGGIE and the young lady to whom he is about to be married were apparently about to traverse," but contrasting Vanderbilt to "the President of the United States" who "is, ex officio, a public and kodakable character. The public has rights in him.").

217. The Protection of Privacy, supra note 215; see McClean, supra note 214, at 497 ("Will not a pen picture as vividly portray the subject and invade privacy? May not a pen portrait offend the feelings and distress the subject more acutely than any other reproduction of a likeness? If so, why should it not be restrained as a violation of the right of privacy?"); Samuel D. Warren \& Louis D. Brandeis, The Right to Privacy, 4 HARv. L. REv. 193, 213-14 (1890) ("The right of one who has remained a private individual, to prevent his public portraiture, presents the simplest case [for a right to privacy; the right to protect one's self from pen portraiture, from a discussion by the press of one's private affairs, would be a more important and far-reaching one."). There are some reasons to believe that Brandeis later changed his position about the relative importance of protecting civility and protecting freedom of expression. See, e.g., NEIL RICHARDS,

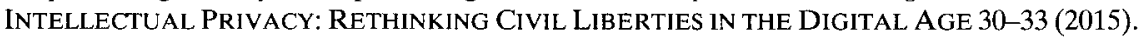

218. But see Portraiture and Privacy, N.Y. TIMES (June 3, 1897), http:/query.nytimes.com/gst/ abstract.html?res=9406E4DB1E39E433A25750C0A9609C94669ED7CF\&legacy=true [https:// perma.cc/TC4N-KAPH] ("It is true that the impertinence of a detailed description of the appearance and dress of a private person may be as impertinent as the unauthorized publication of the pretended portrait of such a person. But it does not produce the same effect."). 
associated with everyday face-to-face, nontextual life. ${ }^{219}$ In our own time, this expectation has blossomed into the plethora of "reality" TV programs in which the public sphere weirdly mirrors the quotidian events of our own lives in the form of publicly circulating audiovisual texts.

Third, the increasingly pervasive dimensions of the mass public sphere produced the experience that it was more influential, more important, more real than the day-to-day interactions of everyday life, ${ }^{220}$ which were conducted on a far smaller scale. ${ }^{221}$ As a result there arose what James called "that mania for publicity which is one of the most striking signs of our times." 222 Contemporaries were impressed by how "the passion for notoriety of any kind has been fostered to such an extent by this wide diffusion of printed gossip, that there is a large number of people who do not dislike it, but on the contrary put themselves in the way of having their private life explored by the press." "223 They found it remarkable that "[m]ost people crave to be lifted out of the morass of anonymity. Any public attention, no matter how foolish it makes them look, is better than none."224 The triumph of

219. See The Protection of Privacy, supra note 215; see also Gill v. Hearst Publ'g Co., 253 P.2d 441, 444-45 (Cal. 1953); H.L. Smith, The News Camera on Trial, 98 FORUM \& CENTURY 267 (1937).

220. As the character of Howard Beale (played by Peter Finch) chides his TV audience in the film NETWORK (Metro-Goldwyn-Mayer 1976), "You're beginning to think that the tube is reality and that your own lives are unreal."

221. SCHUDSON, supra note 154, at 19-20.

222. JAMES, supra note 145 , at 82 . See generally RICHARD SALMON, HENRY JAMES AND THE CULTURE OF PUBLICITY (1997) (exploring the concept of publicity in the writings of Henry James).

223. E.L. Godkin, The Rights of the Citizen. IV. - To His Own Reputation, 8 SCRIBNER'S MAGAZINE 58, 66 (1890). Charles Dudley Warner, commenting on "the mania in this age, and especially in America, for notoriety, in social life as well as in politics," remarked:

Almost everybody talks about the violation of decency and the sanctity of private life by the newspaper in the publication of personalities and the gossip of society. And the very people who make these strictures are often those who regard the paper as without enterprise and dull if it does not report in detail their weddings, their balls and parties, the distinguished persons present, the dress of the ladies, the sumptuousness of the entertainment, if it does not celebrate their church services and festivities, their social meetings, their new house, their distinguished arrivals at this or that watering-place.

Warner, supra note 141 , at $61-62$.

224. Mitchell Dawson, Law and the Right of Privacy, 67 AM. Mercury 397, 404 (1948) [hereinafter Dawson, Law]. "The average newspaper reader would give what passes tor his soul to strut just once across the headlines in any role, no matter how ignominious. . . . [T]he majority ... step eagerly into the range of every newspaper and movie camera, and send in their names by the thousand to have them announced over the radio. In this way, or by the more arduous means of marathon dancing or flagpole sitting, every undistinguished ego may escape anonymity for at least a few brief ecstatic moments." Mitchell Dawson, Paul Pry and Privacy, 150 
news made people hunger not only to read the news, but also to enter the textual world of media by becoming news. ${ }^{225}$

As news became "a dominant force in the public construction of common experience," it also became an arbiter of the "popular sense of what is real and important."226 Thus "some people think that no pleasure is fully enjoyed until an account of it is published." 227 To such persons "the journalist is the man who holds the key of their paradise," and they will voluntarily cede to him elaborate accounts of their own private entertainments - "that Mrs. A. wore a dress made en train, and Mrs. B. one with a waist cut a la Pompadour, and Miss C. carried a panier, and Miss D. something fichu."228 "The people whose names are printed are shocked ... they declare ... that they are disgusted with the prying, vulgar newspaper that contains them; but they want to see the paper, and they run their eyes down the column in search of the names of their friends." 229 In this way, the triumph of news not only undermined traditional elite etiquette from within, but it also brought public attention and significance to the "unimportant persons" singled

AtLANTIC MONTHLY 385, 387 (1932); see Meyer Berger, Surrender of Privacy, SCRIBNER'S MAG., Apr. 1939, at 16.

225. "[T] $[$ he passion for notoriety on the part of obscure people" is "one of the strongest of social forces today." The Right to Privacy, 51 NATION 496, 497 (1890).

226. SCHUDSON, supra note 163 , at 13 . Schudson describes the role of a news story in validating public attention:

A news story is an announcement of a special kind. It is not like an advertisement, the self-interested purpose of which one can presume. It is not like a public relations event, which is suspect on its face. It is a declaration by a familiar commercial or state agency, staffed by news professionals, that an event is noteworthy. It announces to audiences that a topic deserves public attention.

Id. at 31; see Richard Grant White, The Pest of the Period: A Chapter of the Morals and Manners of Journalism, 9 THE GALAXY: AN ILLUSTRATED MAGAZINE OF ENTERTAINING READING 102, 107 (1870) ("The mere mention of a man in connection with public affairs by a newspaper of any position gives him a certain importance, or at least the notoriety which it is his object to attain.").

227. White, supra note 226 , at 106.

228. Id.

229. Charles Dudley Warner, Newspapers and the Public, 9 Forum 198, 204 (1890). It was for this reason difficult "to persuade the people who publish these things that the people about whom they are published really dislike them." The Right to Privacy, N.Y. TimEs (Mar. 15, 1889), http:// query.nytimes.com/mem/archive-free/pdf?res=9B05E3DA163BE033A25756C1A9659C94689F D7CF [https://perma.cc/55MK-HDOY]. This was especially true because

[e]xperience leads them to the contrary conclusion - that the subjects enjoy and take a pride in elaborate descriptions of themselves and their belongings so long as the description is admiring and not satirical. This is so far true that most women who take part in social 'functions' of which descriptions appear in the newspapers would probably regard themselves as rather slighted than honored if the dresses of their neighbors were described and their own were omitted. 
out for attention by reporters, thereby disrupting traditional standards of merit. ${ }^{230}$

Finally, the triumph of news created not only the urgent need to become visible by being the object of press attention, ${ }^{231}$ but also the irresistible urge to see, to shine "[t]he white light of publicity"232 wherever public curiosity might be aroused. James had it exactly right when he observed that "[o]ne sketches one's age but imperfectly if one doesn't touch on that particular matter: the invasion, the impudence and shamelessness, of the newspaper and the interviewer, the devouring publicity of life, the extinction of all sense between public and private. It is the highest expression of the note of 'familiarity,' the sinking of manners, in so many ways, which the democratization of the world brings with it." 233

The press was shameless because it refused to be bound by the "manners" that defined elite society. ${ }^{234}$ The press was accused of "overstepping in every direction the obvious bounds of propriety and of decency." ${ }^{235}$ It overstepped by unleashing a "flood of journalistic filth issuing from the great cities" ${ }^{\prime 236}$ that spilled across domestic thresholds, puddling on the breakfast table where it spoke of things that a man ought not be able to "tell his wife and children face to face.

230. White, supra note 226 , at 106.

231. For a discussion of the resulting "struggles for visibility" which have come to dominate the public sphere, see THOMPSON, supra note 149, at 245-47.

232. McClean, supra note 214 , at 494.

233. JAMES, supra note 145 , at 82 .

234. On these manners, see Norton, supra note 207, at 645 , decrying the "gross[] exhibition of boorishness tha[t] was recently displayed by the well-to-do-crowds at the Horse Show in New York, in their behavior toward the young Duke and Duchess of Marlborough[]-women and men crowding and hustling to get a place from which to stare at the newly-married pair, vying with each other in the shameless manifestation of the want of self-respect, as well as of decent regard not merely to conventional but to actual propriety."

235. Warren \& Brandeis, supra note 217, at 196; see White, supra note 226 , at 105 ("This sort of journalism is carried beyond the bounds of the commonest decency."). White continued:

In regard to persons, the rule of decent journalism is very clear and very easy to be followed. It is to respect absolutely the barrier of private life. A man's public course, his speech, his book, his picture, his suit at law, his breach of the public peace, his contract with the Government, whatever, in brief, brings him into relations with the public, is proper subject of comment with the journalist. But his personal affairs, his relations with his family, his friends, acquaintances, clients and customers, no man has a right to bring before the public but himself; and for him to do so is a breach of good taste which an editor should not permit, except in the way of paid advertisement. For the journalist to pass the barrier of private life, whether to praise or to blame, should be by law, in itself, a libel.

White, supra note 226 , at 111-12.

236. Garnsey, supra note 201. 
Our 'dailies' at present are rarely fit for home-reading without thorough expurgation." 237 It overstepped by prying into the details of personal life. "[J]ournalism plucks off the roof, and pulls down the walls and sheltering partitions, and wantonly lays bare all the defilement and consuming lust of poor human nature." 238 It overstepped by using its "hungry eyes" to violate "the sanctities of domestic life and marriage," and to "peer into private houses, study banquets, balls, teas, - read the tempting menus by this great caterer, criticise the 'decorations' by that crack florist, note the brands of champagne, audit the very sum-total of the outlay ...."239

James was correct that the overstepping of newspapers corroded conventional boundaries. Newspapers overstepped "to gratify the curiosity" 240 of a mass public, and so to increase circulation and profit. ${ }^{241}$ From one point of view, therefore, the commercial market was eroding essential conventions of life, conventions that the novelist William Dean Howells called the "tissue of hypocrisies, beginning with the clothes in which we hide our nakedness" that make up "society, as we have it." 242 But from another point of view newspapers were responding to a mass public that wanted to understand the society around them. Refugees and strangers of all stripes, "[g]reenhorn immigrants, women entering a freer life, and recent arrivals from the country," ${ }^{243}$ all unacquainted with the niceties of social conventions,

\footnotetext{
237. Rider, supra note 195, at 476; see Speed, supra note 208, at 708-09.
}

238. Rider, supra note 195 , at 477 . "A man's private life is inviolably his own, be he the lowliest or the highest in the land, be he the most prominent official or the obscurest citizen. Over his own threshold it is lawful for no intruder to put his foot." Pallen, supra note 194, at 476.

239. Rider, supra note 195, at 479.

240. White, supra note 226 , at 102 . White continued:

The first object of the journalist's life, in his opinion, is to excite and to gratify the curiosity of his readers, at whatever cost. Therefore if he hear a flying report which couples the names of a man and a woman, either of whom is distinguished enough or rich enough to be talked about by a few hundred people, he announces their engagement, in doing which he generally does no greater wrong than the publication to the world of what is of no consequence to any person outside of their circle of personal acquaintance, in this being guilty of an impertinence for which he should be punished.

Id. at $102-03$.

241. How is it, American essayist and novelist Charles Dudley Warner asked, "that the newspapers most sensational, most vulgar, most chaotically conducted, are precisely those that have the largest circulation?" Warner, supra note 229, at 200; see The Right to Privacy, supra note 225, at 497 (noting "the great commercial demand for scandal and gossip" and observing that newspapers featuring such content generated "the very greatest and most rapid commercial successes of our day" in proportion to how "plentifully" (hey could "supply this demand").

242. HOWELLS, supra note 184 , at 280.

243. Helen MacGill Hughes, Human Interest Stories and Democracy, 1 PUB. OPINION Q. 73, 
were curious about every aspect of urban life. They wanted to make sense of the richness and wonder of their own experience.

Seen from this angle, James was also accurate to connect the loss of privacy to "the democratization of the world." The privacy devoured by newspapers, like the privacy at issue in Article 7 of the Charter, exists only as it is defined and constituted by customs and mores. Customs and mores are always relative to a given group or class. As The Nation observed, "privacy has a different meaning to different classes or categories of persons; it is, for instance, one thing to a man who has always lived in his own house, and another to a man who has always lived in a boarding-house." 244 Given "the extremely democratic condition of American society," 245 those in boarding houses were not inclined to let the scruples of those in mansions frustrate their efforts to comprehend their urban environment. ${ }^{246}$ For their part, elites regarded the responsiveness of newspapers to public curiosity as "pandering to the baser tastes and dispositions of the community,"247 to "the taste and standards of judgment of the uneducated and unrefined masses, over those of the more enlightened and betterinstructed few." 248

From this perspective, the responsiveness of newspapers to consumer demand was ultimately a political question. The broader the public to which newspapers responded, the more democratic was the

82 (1937)

244. The Right to Privacy, supra note 225, at 497.

245. Godkin, supra note 223, at 67.

246. "In all democratic societies to-day the public is disposed either to resent attempts at privacy, either of mind or body, or turn them into ridicule. There is nothing democratic societics dislike so much to-day as anything which looks like what is called 'exclusiveness,' and all regard for or precautions about privacy are apt to be considered signs of exclusiveness." The Right to Privacy, supra note 225, at 496-497.

247. Norton, supra note 207, at 647.

248. Norton, supra note 193, at 321. In explaining the attraction of the news, George Herbert Mead stressed the "inchoate phenomenon of the human reveric, which the press and the movic have projected before us":

We are apt to consider it as a purely private affair with each individual, his desultory meanderings of idea and purpose and imagery, perhaps more gruesomely presented in James Joyce's Ulysses, than elsewhere in literature. It is, indeed, infected with privacy and therefore subject to disintegration. But it passes into the universal meanings of common discourse and co-operative effort .... It is that part of the inner life of man which cannot be given its implicated meaning because of the incompleteness of social organization. It marks man's isolation within society. We have decried its vulgarity when the daily press and the movie films have stripped off its privacy. It is better, however, to live with our problems than to ignore them.

Mead, supra note 171, at 393. 
public sphere which they created. ${ }^{249}$ That is why our most thoughtful media analysist, Michael Schudson, has concluded that "a media system dedicated to democracy" should aspire to "provide the quantity and quality of news that people want; that is, the market should be the criterion for the production of news. (In other words, the news media should adhere to the rule that many critics insist drives the press toward the sensational, the prurient, and the trivial.)" ${ }^{\prime 250}$ Schudson's conclusion expresses the principle that in a democracy the interests of the public must set the agenda for government action and not the other way around. Were the state on grounds of "taste" and "judgment" to curtail the circulation of news interesting to the public, government would in effect be setting its own agenda.

This tension played out in especially stark terms at the turn of the twentieth century. Americans were then fascinated with "personalities"; they took "an interest in humanity, a lively concern in the fortunes of others," which no doubt was "due to the fluid, changing nature of our society, the possibility of its ups and downs, which keeps everyone on the qui vive."251 In politics also "the real interest of the voter at our elections is usually in personality. . . On this shrewd judgment of persons the advocate of democracy chiefly grounds his faith that the people will be right in the long run."252

To provide information about personality, however, was directly to challenge "the traditional reserve of educated people." ${ }^{253}$ Journalists nevertheless forthrightly defended their reporting on the details of personal life:

There was a day when any allusion to the personal appearance, the habits, the clothes, or the home and social life of any person, would have been resented as an impertinence and almost as an indecency.... But ... I hold the desire for personal details with regard to public men is healthy, rational, and should be yielded to. Statesmen are not ciphers without form or blood or passion. Their utterances

249. It is noteworthy that at about this time American public libraries began to shift their sense of mission from providing the public with the best books available for their education, to meeting the demand for books that the public wanted to read. ARTHUR E. BOSTWICK, THE American Public Library 1-4 (1929); WAyne Bivens-Tatum, Libraries and the ENLIGHTENMENT 133-34 (2012). This shift in function was highly controversial.

250. SCHUDSON, supra note 154 , at 28-29.

251. Warner, supra note 229 , at 203. "[A] new society is naturally more interested in the details of its evolution than an old and settled society in which fortunes are fixed and changes are rare." Id. at $203-04$.

252. COOLEY, supra note 146 , at 143 .

253. In Defence of Privacy, 130 Saturday REv. 155, 155 (Aug. 21, 1920). 
and acts are not pure intellectual secretions. If you want to know how such and such an act of weakness or folly is intelligible at some crisis in the history of a politician, you must have learned something more of the politician than you can get from the verbatim report of his speeches, or the colourless and dry language of his public documents. Behind every speech and every act there is the man - a weak man or a strong man, high or low, generous in purpose or base in intrigue. You cannot get rid of this background if you want to describe the event accurately. ${ }^{254}$

The search for "personal details" was particularly urgent because of the growing conviction that public actions and professions were masks that disguised real or authentic personality, which was thought to be revealed only in private where persons were free from "the contrived, mannered self-presentation" characteristic of the public sphere. ${ }^{255}$ Public curiosity thus focused ever more sharply on domains previously deemed private. Journalists developed techniques to expose these domains. A good example is the journalistic "interview," which was at first condemned as an impertinent intrusion, ${ }^{256}$ but which was defended as "the only means by which the public can learn some things which it has a distinct right to know and which it is the interest of designing persons to conceal." 257 The rapid expansion of photographic journalism was another technique to render visible candid views that the public would not otherwise be able to see..$^{258}$

As a result of these developments, it became clear that by the middle of the twentieth century, except in cases of especially heinous invasions of privacy, "a man's life belongs to Demos. The People want

254. O'Connor, supra note 175 , at 423, 428-29.

255. Charles L. PONCE DE LeOn, Human-INTEREST JOURnalism AND the EMERGENCE OF CELEBRITY IN AMERICA 1890-1940, at 29 (2002). Leon continues:

By the mid-nineteenth century the residents of cities in the United States, England, and many areas of Western Europe had concluded that everyone employed fronts when in public, and that all self-presentation in the public sphere was, to one degree or another, artificial and unreliable as a guide to a person's real self. When encounter[ing] a person in the public sphere it was safe to assume that she was acting, engaged in the perpetual confidence games that had come to shape social and economic relations in cities and would eventually become a salient feature of modern life. To glimpse a person's real self it was necessary to see her in private, when she dropped her front and refrained Id. from the contrived, mannered self-presentation that she adopted in the public sphere.

256. O.B. Frothingham, The Interviewer, FoRum, Apr. 1886, at 183. The Abolition of Privacy, N.Y. TIMES (Aug. 4, 1874), http:/query.nytimes.com/mem/archive-free/pdf?res=990DEED9143 BEF34BC4C53DFBE66838F669FDE [https://perma.cc/CB8Q-VPR7].

257. The Interview, NEW PRINCETON REV., Jan. 1887, at 127.

258. Speed, supra note 213 , at 73. 
to know how he looks, how he lives, how he loves and every other detail that reporters and cameramen care to exploit."259

\section{GoOGLE AND THE PUBLIC SPHERE}

The creation of a mass public oriented around the consumption of news effaced boundaries that had previously separated private from public life. It did so through the medium of newspapers, which functioned as agents of a growing public curiosity fueled by an emergent mass participation in the public sphere. As the textual world of the public sphere came to seem more real and important, its demands increasingly came to dominate prior customs and mores, which in the United States began to fade into the pale and etiolated world of cloistered elites. These developments were self-enforcing.

One of my favorite Norman Lincoln Rockwell illustrations portrays a young girl of about eight or nine in a drab white nightgown, gazing wistfully into a full-length mirror in the attic. ${ }^{260}$ At her feet are a comb, brush and opened lipstick; on her lap is a black-and-white photograph of a glamorous movie star in a magazine. The girl identifies with a celebrity whom she has encountered only through media; she is striving to make herself into an image that comes to her only as text circulating in the public sphere. She is learning to imagine herself as a member of a public. The photograph of the celebrity, even though it is without color, has assumed for her an importance and reality that eclipses her seemingly dull everyday existence. Her actual life is at risk of being displaced by the immense and irresistible force of media textuality.

As the press satisfied the curiosity of ordinary people, ordinary people came to identify with the texts circulated in the public sphere by the press. ${ }^{261}$ This cycle of gratification and identification created a powerful structure of mutual interdependence that could not be interrupted without the exercise of considerable social authority. But as norms of privacy inconsistent with the demands of the public sphere came to seem increasingly elitist and self-serving, the source of any such authority was less and less obvious. ${ }^{262}$ As a sociological matter,

259. Dawson, Law, supra note 224, at 397.

260. This painting was the cover of the Saturday Evening Post on March 6, 1954. For a blackand-white reproduction, see infra Appendix.

261. See THOMPSON, supra note 151, at 211.

262. One may perhaps speculate that norms of privacy have remained much stronger in Europe because the prestige of elites has been much less diminished than in the United States. 
therefore, and quite apart from any constitutional restraints, courts in the United States became quite cautious in defining and applying the tort of invasion of privacy.

Of particular interest is the development of New York law. In 1902, the New York Court of Appeals refused to create a common law tort of invasion of privacy. ${ }^{263}$ The decision provoked a storm of controversy, ${ }^{264}$ and the New York legislature responded by enacting Section 50 of the New York Civil Rights Law "forbidding the use of a person's name, picture or portrait for advertising purposes or purposes of trade, without his written consent first being obtained." ${ }^{265}$ In interpreting the law, however, New York courts were careful to hold that the statute did not apply to the publication of photographs in a newspaper "in connection with an article of current news or immediate public interest." ${ }^{266}$ New York courts refused to classify newspapers as publishing "for purposes of trade" when they were reporting the news. ${ }^{267}$

New York courts were aware the newspapers were commercial enterprises that sold news for a profit. But they believed that the literal terms of the statute could not be applied to newspapers selling news without damaging the "free press" necessary for "fundamental democratic institutions." 268 This interpretation of the statute is striking for its explicit recognition that the commercial press is indispensable for the formation of a public sphere and hence for the formation of public opinion. It understands that the press as an institution is the vehicle for a general public interest in maintaining public discourse. The public interest in maintaining public discourse does not depend upon the contents of any specific article, but instead on the structural properties of the press as a medium for the dissemination of news. ${ }^{269}$

This approach stands in stark contrast to Google Spain, which holds that Google as a commercial company can assert only its own

\footnotetext{
This prestige creates an aristocratic counterforce to the demands of mass curiosity.

263. Roberson v. Rochester Folding Box Co., 64 N.E. 442, 443 (1902).

264. Louis Nizer, The Right of Privacy: A Half Century's Developments, 39 Mich. L. REV. 526, 532-33, 538 (1941).

265. Lahiri v. Daily Mirror, Inc., 295 N.Y.S. 382, 384 (N.Y. Sup. Ct. 1937).

266. Id.

267. Id. at 387-89; see also Kline v. Robert M. McBride \& Co., 11 N.Y.S.2d 674, 679 (N.Y. Sup. Ct. 1939).

268. Lahiri, 295 N.Y.S. at 388.

269. In terms of American constitutional law, the press constitutes a "medium for the communication of ideas." See Robert C. Post, Recuperating First Amendment Doctrine, 47 STAN. L. REv. 1249, 1250-60 (1995) (quoting Joseph Burstyn, Inc. v. Wilson, 343 U.S. 495, 501 (1952)).
} 
economic interests and that any public interest in circumscribing the application of the Directive is confined to websites that contain specific kinds of information as, for example, personal information about a data subject who has played a prominent role in public life. The reasoning of Google Spain misses what we can learn from the history of newspapers: there is a strong public interest in maintaining a vigorous press, regardless of whether the press is run for commercial reasons and regardless of the exact contents of any particular items in the press. This interest exists because the press, by appealing to broad swatches of public curiosity, sustains the very possibility of a "public," without which the emergence of public opinion is impossible.

The Directive seems to acknowledge these points when it authorizes a derogation for "the processing of personal data carried out solely for journalistic purposes" insofar as such a derogation is "necessary to reconcile the right to privacy with the rules governing freedom of expression."270 The GDPR analogously provides that "Member States shall by law reconcile the right to the protection of personal data ... . with the right to freedom of expression and information, including processing for journalistic purposes." ${ }^{271}$ And, of course, Article 11 of the Charter provides that " $[\mathrm{t}]$ he freedom and pluralism of the media shall be respected."272

These provisions point to the essential question of whether we should regard Google as serving journalistic purposes. It is noteworthy that the CJEU denies that search engines like Google can serve journalistic purposes; it concludes that Google can claim only the economic interests of a private commercial company. But the rise of the modern American press has much to teach us about the legal characterization that ought to be applied to Google.

The nineteenth-century American reader believed that the newspaper gave "him the daily history of the world (and most of the ideas that he uses in conversation)."273 Newspapers scoured the world to bring readers an enormous catchment of information that was far larger than any individual reader could gather for herself. Newspapers brought these texts to readers in ways designed to attract their attention - through headlines, illustrations, human interest stories, or short, punchy prose. Newspapers also created their own news by

\footnotetext{
270. Directive, supra note 5, art. 9.

271. GDPR, supra note 17 , art. 85 .

272. Charter, supra note 9, art. 11.

273. Warner, supra note 229 , at 206.
} 
muckraking investigations, interviews, and so on. They shifted the balance of the demos' identification away from the embodied, face-toface relationships of everyday life and toward the textually mediated connections of the public sphere. They allowed readers to conceive themselves as a public and hence as participants in the formation of public opinion. And newspapers sought through editorials and other means to shape public opinion on issues of the day.

At first blush, Google could not be less like a newspaper. It is an "indexing tool used to locate web sites that correspond to a user's search query." 274 It locates websites with automated web crawlers, not reporters. It uses algorithms rather than editors to arrange the presentation and priority of these websites. It does not muckrake, or investigate, or create human interest stories. It does not publish editorials to influence the content of public opinion. If a newspaper readily lends itself to characterization as a speaker or author, Google does not. Although it is easy to attribute to newspapers the protections of freedom of expression that we accord to speakers who participate in public discourse, it requires difficult work to characterize Google in that way. ${ }^{275}$

Our short history of the American press, however, suggests that newspapers serve an essential public interest quite apart from their being speakers. By continuously circulating texts that engage mass readers, newspapers create a public sphere in which readers can imagine themselves both as persons who see the world through texts, and as persons who are seen by the world as texts. In effect, newspapers create the conditions in which readers conceive themselves as a public, and hence as implicated in the formation of the public opinion that is essential to a democracy.

Google also serves this essential public interest. The Internet is a massive collection of information in which texts circulate online just as they do in material form. "[I]n . . . light of its accessibility and its

274. Search King, Inc. v. Google Tech., Inc., No. CIV-02-1457-M, 2003 WL 21464568, at *1 n.1 (W.D. Ok. May 27, 2003).

275. Although this has not prevented some from advancing this analogy. Compare Eugene Volokh \& Donald M. Falk, Google: First Amendment Protection for Search Engine Search Results, 8 J.L. ECON. \& POL'Y 883, 884-85 (2012), with Tim Wu, Machine Speech, 161 U. PA. L. REv. 1495, 1528 (2013), and Heather M. Whitney \& Robert Mark Simpson, Search Engines and Free Speech Coverage, in FREe SPEECH IN THE Digital Age (Susan J. Brison \& Kath Gelber eds., forthcoming) (manuscript at 11-17). At different times, and in different contexts, Google has sometimes sought to characterize itself as a speaker, and sometimes not. Jeffrey Abramson, Searching for Reputation: Reconciling Free Speech and the "Right to be Forgotten," 17 N.C. J.L. \& TECH. 1, 34-40 (2015). 
capacity to store and communicate vast amounts of information, the Internet plays an important role in enhancing the public's access to news and facilitating the dissemination of information in general.".276 But the Internet is opaque unless readers are equipped with tools to locate texts that answer to their curiosity. Google provides such tools and so brings us our "daily history of the world." "We use search engines to learn about and make sense of the world, to answer our questions, and as aids to our thinking." 277 In this sense, "Google and similar search engines are . . increasingly becoming our windows to the world." 278

By the end of the nineteenth century, newspapers were defining news as that which interests the public. News enticed and sustained mass participation in the formation of public opinion. From this perspective, Google is a preeminent portal through which millions of readers receive news. Readers use Google to search out texts that interest them. By using Google, readers interact with each other and become themselves visible as texts. Google is thus an essential infrastructure for the modern virtual public sphere. The virtual public sphere becomes more democratic as a mass audience is able more easily to participate in its construction, and as they are able to acquire information responsive to their own interests. ${ }^{279}$ But the implication of

276. Case of Magyar Tartalomszolgáltatók Egyesülete \& Index.hu Zrt v. Hungary, App. No. 22947/13, para. 56 (Eur. Ct. H.R. Feb. 5, 2016), http://hudoc.echr.coe.int/eng?i=001-160314 [https://perma.cc/MK8F-B4LM]; see Fredrik Neij \& Peter Sunde Kolmisoppi v. Sweden, App. No. 40397/12, at 9 (Eur. Ct. H.R. Feb. 19, 2013), http://hudoc.echr.coe.int/eng?i=001-117513 [https:// perma.cc/E8CG-JF78]. As the U.S. Supreme Court recently affirmed:

A fundamental principle of the First Amendment is that all persons have access to places where they can speak and listen, and then, after reflection, speak and listen once more. The Court has sought to protect the right to speak in this spatial context. A basic rule, for example, is that a street or a park is a quintessential forum for the exercise of First Amendment rights. Even in the modern era, these places are still essential venues for public gatherings to celebrate some views, to protest others, or simply to learn and inquire.

While in the past there may have been difficulty in identifying the most important places (in a spatial sense) for the exchange of views, today the answer is clear. It is cyberspace - the "vast democratic forums of the Internet" in general and social media in particular.

Packingham v. North Carolina, 137 S. Ct. 1730, 1735 (2017) (citations omitted).

277. RICHARDS, supra note 217 , at 122 . Richards sensibly uses this premise to defend the privacy of the data gathered by Google about those who use Google.

278. Sylvia de Mars \& Patrick O'Callaghan, Privacy and Search Engines: Forgetting or Contextualizing, 43 J.L. \& SoC. 257, 267 (2016). "Imagine . . if a library were to tell you that information might be found in its vast, unorganized stacks, but that it could not offer an index to assist the search for information." Anupam Chander \& Uyen P. Le, Free Speech, 100 IowA L. REV. 501,542 (2015).

279. As the European Court of Human Rights observed, the "Internet has now become one 
this social structure is that the virtual public sphere "devours" more efficiently than ever before the traditional boundaries that separate public from private aspects of life. ${ }^{280}$

An important difference between Google and a newspaper is that the latter must entice readers to purchase news through devices like human interest stories, headlines, and photographs. By contrast, Google does not need to solicit readers to seek news. Instead readers bring their interests to Google. More than any newspaper, Google allows its readers to pursue their own curiosity by searching for news that is of interest to them. ${ }^{281}$ Like a newspaper, Google presents this news in a fragmentary, disjointed way, which allows readers to draw their own conclusions about the meaning of news. Like a newspaper, Google disrupts elite narratives and authority. In the antinomian world of the modern Internet, readers would feel disempowered were the state to prevent them from accessing texts about which they were curious unless those texts were first vetted, researched, referenced and composed by professional journalists or scholars. ${ }^{282}$

Whether readers obtain their news from a newspaper or from Google, they participate in the circulation of texts and so are drawn to participate in the formation of the public sphere. The attraction is as forceful with Google as it is with newspapers. ${ }^{283}$ In the context of the virtual public sphere, "[t]o die is to be disconnected from access to the archives, not jacked-in or not in real-time." ${ }^{284}$ Just as New Yorkers felt

of the principal means by which individuals exercise their right to freedom of expression and information, providing as it does essential tools for participation in activities and discussions concerning political issues and issues of general interest." Case of Ahmet Yildirim v. Turkey, App. No. 3111/10, para. 54 (Eur. Ct. H.R. Dec. 18, 2012).

280. Case of Editorial Board of Pravoye Delo \& Shtekel v. Ukraine, 2011-11 Eur. Ct. H.R. 383,401 . ("The risk of harm posed by content and communications on the Internet to the exercise and enjoyment of human rights and freedoms, particularly the right to respect for private life, is certainly higher than that posed by the press.")

281. Of course it is true that the algorithms used by Google to determine search outcomes will aggregate and display to readers their own interests in particular ways, but at most this is a vague echo of the "editorial judgment" that every newspaper has always had to employ. The same may be said of Google's Autocomplete function, which a German court has found can invade a person's personality rights by suggesting untrue associations. DANIEL J. SOLOVE \& PAUL M. SCHWARTZ, INFORMATION PRIVACY LAW 1156-57 (5th ed. 2015).

282. This would be the consequence of interpreting the Directive and the GDPR to authorize derogations for "journalist purposes" only when such purpoes are controlled by professional journalists.

283. For a good discussion of the compelling attraction of the Internet public sphere, see Adrian Mackenzie, The Mortality of the Virtual: Real-time, Archive and Dead-time in Information Networks, CONVERGENCE, June 1997, at 59.

284. Id. at 66. 
lost without their daily newspapers, so contemporary persons feel lost when their access to the Internet fails. Hardly a day goes by that I do not use Google to find texts that interest me online.

The news I locate on Google, like the news I read in a newspaper, orients me to public questions. It allows me to conceive myself as participating in the formation of public opinion and hence as democratically involved. One can test the robustness of this conclusion by imagining what would have happened were former President François Hollande to have prohibited Google from linking to sites that mentioned former French presidential candidate Marine Le Pen. ${ }^{285}$ No one would doubt that public interests of the highest order would be at stake. The analogy to print media is immediate and convincing. The ECtHR has stressed "the substantial contribution made by Internet archives to preserving and making available news and information. Such archives constitute an important source for education and historical research, particularly as they are readily accessible to the public and are generally free."286 The court has even emphasized the connection between this contribution and the "function of the press in a democracy," insofar as that function includes "maintaining and making available to the public archives containing news which has previously been reported. The maintenance of Internet archives is a critical aspect of this role." 287

By establishing the infrastructure that sustains the virtual public sphere, Google serves the same essential democratic interests as does the traditional press. The fact that it does so for profit no more counts against it than it does against the "media" that Article 11 of the Charter explicitly protects. Every democratic state extends constitutional protections to the media "not for the benefit of the press so much as for the benefit of all of us. A broadly defined freedom of the press assures the maintenance of our political system and an open society." 288 The unusual market dominance of Google as a search engine may indeed raise legitimate concerns, but these concerns ultimately sound in antitrust law and do not undermine the conclusion that search engines in general serve the same public interest as does the press. Just as antitrust standards may, with appropriate safeguards, be applied to

285. I am grateful to Dan Solove for this hypothetical.

286. Case of Węgrzynowski \& Smolczewski v. Poland, App. No. 33846/07, para. 59 (Eur. Ct. H.R. July 16, 2013), http://hudoc.echr.coe.int/eng?i=001-122365 [https://perma.cc/GQ2J-8K8Z].

287. Id.

288. Time, Inc. v. Hill, 385 U.S. 374, 389 (1967). 
traditional media outlets, so they may be applied to Google. ${ }^{289}$

Google Spain failed to acknowledge the public interests served by Google. It was not curious about the structure of communication that might be necessary for democracy to function. It did not raise the possibility that Google might share some of the "journalistic purposes" for which the Directive explicitly authorizes a derogation. This may be because Europeans have always been primarily focused on journals of opinion, so that they cannot even imagine the exercise of "journalistic purposes" without the concomitant exercise of authorial voice. ${ }^{290}$ It may also be because the CJEU could not perceive in Google the exercise of that independent professional judgment which in the past has been exercised by journalists who selected, authored, and presented the news. ${ }^{291}$

The history of newspapers in Part II, however, suggests that democracies require a vigorous press in order to create a communicative infrastructure for the public sphere. The media circulate information that incites the common attention of strangers, and thus establish a public. Google unquestionably serves this purpose in an Internet age, even though Google does not itself speak in the traditional journalistic way. Google helps to create a "public" in the same manner as did the nineteenth- and twentieth-century press. For that reason, it implicates the same democratic values of freedom of expression as does the traditional press.

\section{GOOGLE, THE RTBF, AND THE Right To BE FORGOTTEN}

Even if it is accepted that Google is invested with a public interest of the kind I have just sketched, it does not follow that the privacy harms caused by Google are without remedy. What follows is that the RTBF, as it is rooted in Article 8 of the Charter and operationalized in the GDPR, should not be enforced against Google. The right to be forgotten, by contrast, which is rooted in Article 7 of the Charter and applied by legal systems in many countries, is specifically designed for

289. ROBERT MCCHESNEY \& JOHN NiCHOLS, THE DEATH AND LIFE OF AMERICAN Journalism: THE MEdia ReVOlution that WiLl BEgin the WorLd Again 61-64 (2010).

290. See Erdos, supra note 69, at 132-38.

291. Mantelero, supra note 40, at 235; see SCHUDSON, supra note 154, at 9-14 (discussing the professionalism of modern journalism). But see James Grimmelmann, Speech Engines, 98 MINN. L. REV. 868, 874-75 (2014) (arguing that Google functions (or should function) as a "trusted advisor"). On different conceptions of journalism within the EU, see generally DANIEL C. Hallin \& PaOlo Mancini, Comparing Media Systems: Three Models of Media and POLITICS (2004). 
application to media in the public sphere. Although data privacy is incompatible with the public sphere, dignitary privacy has regulated press publications for more than a century.

\section{A. Google and the RTBF}

The GDPR defines the RTBF as the right to have personal data erased "without undue delay" if they are "no longer necessary in relation to the purposes for which they were collected or otherwise processed." ${ }^{292}$ This is an intelligible inquiry with respect to large organizations that collect and process data for managerial reasons. But it is not an intelligible inquiry with respect to much communication of personal data within the public sphere. We might ask, for example, what purposes a blogger serves when publishing on the Internet an account of contemporary events that contains personal data. If the purpose is to instruct the mind of the public, when is her processing of those data no longer "necessary"?

It is even less clear what specific purposes are independently served by Google. We are now not focused on the data that Google gathers on its customers to effect "massive online capturing of everydayness," ${ }^{293}$ which Harvard Business School Professor Shoshana Zuboff has labelled "surveillance capitalism." 294 Such data should indeed be governed by the instrumental logic of the Directive, because it is almost certainly captured and processed for utilitarian purposes. We are speaking instead of information that Google communicates to the public sphere in the form of links that enable persons to negotiate the worldwide web. When are such Google links "inadequate, irrelevant or no longer relevant, or excessive ${ }^{" 295}$ for the purposes for which they are created?

I have often heard it said that the Internet "never forgets." ${ }^{296}$ If

292. GDPR, supra note 17, art. 17; cf. Google Spain, supra note 12, para. 94 ("[I]nformation appears ... to be inadequate, irrelevant or no longer relevant, or excessive in relation to the purposes of the processing at issue carried out by the operator of the search engine, the information ... must be erased.").

293. Ionna D. Constantiou \& Jannis Kallinnikos, New Games, New Rules: Big Data and the Changing Context of Strategy, 30 J. INFO. TECH. 44, 55 (2015).

294. Shoshana Zuboff, Big Other: Surveillance Capitalism and the Prospects of an Information Civilization, 30 J. INFO. TECH. 75, 75 (2015).

295. Google Spain, supra note 12, para. 94.

296. Nick Miller, The Internet Never Forgets, Sidney MORNING HERALD (Mar. 23, 2013), http://www.smh.com.au/technology/the-internet-never-forgets-20130322-2gle7.html [https:// perma.cc/F6YA-EMUF]; Jeffrey Rosen, The Web Means the End of Forgetting, N.Y. TiMES MAGAZINE (July 21, 2010), http://www.nytimes.com/2010/07/25/magazine/25privacy-t2.html? 
newspapers are "cheap, quotidi[a]n, throw-away" objects, ${ }^{297}$ largely written to be read and discarded, Google is designed to create usable access to whatever texts are available for circulation in the public sphere of the Internet. ${ }^{298}$ The digital world of the web is "unforgiving" and comprehensive. ${ }^{299}$ In effect, Google creates a moving archive that corresponds to the Internet itself. ${ }^{300}$ The purpose of such an archive is in some respects comparable to the purpose of library archives, which are dedicated to providing "the public the means of acquiring information, knowledge, education, aesthetic experience, and entertainment." 301

Like Google, libraries "organize" available texts - "factual, imaginative, scientific, and humanistic"-through "an effective network" that permits "access . . . from a myriad of directions." Libraries seek to provide information adequate to satisfy the "curiosity and aspiration and appreciation that characterize[] the alert, sensitive, adventurous human being." 303 Libraries strive "to provide all people with access to the information they want." ${ }^{" 304}$ As libraries become

pagewanted=all [https://perma.cc/5N6Y-PPED]; David Siesage, The Internet Never Forgets, So Be Careful What You Put on It, INDEPENDENT (Aug. 28, 2013), http://www.independent.co.uk/ student/istudents/the-internet-never-forgets-so-be-careful-what-you-put-on-it-8787706.html [https://perma.cc/4QSR-HX9K].

297. SCHUDSON, supra note 154 , at 33.

298. See Emily B. Laidlaw, Private Power, Public Interest: An Examination of Search Engine Accountability, 17 INT'L J.L. \& INFO. TECH. 113, 116 (2009) ("[S] earch engines are websites that help users find information on other websites.").

299. MAYER-SCHÖNBERGER, supra note 46 , at 126 (noting that digital memory is "easy to use and comprehensive" with "too strict and unforgiving a link to our past").

300. In Case of Times Newspapers Ltd. (Nos. 1 and 2) v. The United Kingdom, 2009-1 Eur. Ct. H.R. 377, the ECtHR acknowledged

the substantial contribution made by Internet archives to preserving and making available news and information. Such archives constitute an important source for education and historical research, particularly as they are readily accessible to the public and are generally free. The Court therefore considers that, while the primary function of the press in a democracy is to act as a "public watchdog", it has a valuable secondary role in maintaining and making available to the public archives containing news which has previously been reported.

Id. at 392-93, para. 45.

301. Redmond Kathleen Molz \& Phyllis Dain, Civic Space/Cyberspace: The AmErican Public Library in the Information Age 2 (1999); see TOM GlynN, Reading Publics: New York City's Public Libraries, 1754-1911, at 3 (2015); W.J. Murison, THE Public library: Its Origins, PurPose, and Significance 77 (3d ed. 1988).

302. ALA's Pub. Library Ass'n Goals, Guidelines \& Standards Comm., A Mission Statement for Public Libraries: Guidelines for Public Library Service: Part 1, 8 AM. LIBR. 615, 619 (1977).

303. Lowell A. Martin, The Public Library: Middle-age Crisis or Old Age, 108 LiBR. J. 17, 22 (1983).

304. Alex Byrne, Freedom of Access to Information and Freedom of Expression in a Pluralist 
digita ${ }^{305}$ and aim for open access, the priority of physical collections diminishes, and libraries become more and more like Google itselfinstitutions dedicated to organizing and presenting online texts. ${ }^{306}$

All agree that library archives serve to sustain "democratic" culture 307 by "recapturing and extending democratic processes and potential" and linking persons to "the public sphere." "T08 "The "allure of the archives," writes French historian Arlette Farge, is the anticipation of a "roaming voyage through the words of others," so that we might "enter into an unending conversation about humanity" and about "the debates that surround us." ${ }^{" 309}$ When might it be said that the data processing required to produce archives for such purposes is no longer

World, 25 INT'L FED'N LIBR. Ass'N J. 223, 225 (1999); see Molz \& DAIN, supra note 301, at 43; Stephen A. Roberts, World Librarianship and the New Europe: An Exploratory Essay, 4 INT'L J. INFO. \& LIBR. RES. 19, 23 (1992).

305. Leonardo Candela, Donatella Castelli \& Pasquale Pagano, History, Evolution and Impact of Digital Libraries, in E-PUBLISHING AND DIGITAL LIBRARIES: LEGAL AND ORGANIZATIONAL Issues 1, 1 (Ioannis Iglezakis, Tatiana-Eleni Synodinou \& Sarantos Kapidakis eds., 2011).

306. See, e.g., William Y. ARMS, Digital Libraries, at ix (2000); William Y. Arms, The Web as an Open Access Digital Library (Oct. 21. 2000), www.cs.cornell.edu/wya/papers/Kyoto2000.doc [https://perma.cc/VVM4-VFSR]. "Public libraries are not only providing Internet and other electronic resources they are joining the Internet themselves." MOLZ \& DAIN, supra note 301, at 187; see Paul Gilster, Digital LITERACy 155-228 (1997). These developments, of course, need to be placed in the context of the online appearance of digital collections of texts and news like, for example, the ProQuest Historical Newspapers database. See Paul M. Schwartz, From Victorian Secrets to Cyberspace Shaming, 76 U. CHI. L. REV. 1407, 1414-18 (2009).

307. The 1979 White House Conference on Library and Information Services affirmed that "publicly supported libraries are institutions of education for democratic living." RESOLUTIONS OF THE WHITE HOUSE CONFERENCE ON LIBRARY AND INFORMATION SERVICES 1979, at 46 (1980); see AlFREd Hessel, A HiSTORY OF LiBRARIES 99-107 (Reuben Peiss trans., 1955); Arthur W. Hafner \& Jennifer Sterling-Folker, Democratic Ideals and the American Public Library, in DEMOCRACY AND THE PUBLIC LIBRARY: ESSAYS ON FUNDAMENTAL ISSUES 9, 19 (Arthur W. Hafner ed., 1993); Frederick Stielow, Reconsidering Arsenals of a Democratic Culture, in LIBRARIES \& DEMOCRACY: THE CORNERSTONES OF LIBERTY 3, 4-5 (Nancy Kranich ed., 2001); Grace O. Kelley, The Democratic Function of Public Libraries, 4 LIB. Q. 1, 1 (1934). The White House Conference resolved that because "information in a free society is a basic right of any individual, essential for all persons ... and all economic and social levels," that "all persons should have free access, without charge or fee to the individual, to information in public and publicly supported libraries." RESOLUTIONS OF THE WHITE HOUSE CONFERENCE ON LIBRARY AND INFORMATION SERVICES 1979, at 46 (1980).

308. John E. Buschman, Dismantling The Public SPhere: Situating and Sustaining LibRARIANSHIP IN THE AGE OF THE NEW PUBLIC PHILOSOPHY 37 (2003); see id. at 46-48, 175; see also JAMES H. BILlington, The Modern Library and Global Democracy, in THE MEANING OF THE LiBrary: A Cultural History 254, 254 (Alice Crawford ed., 2015) ("[L]ibraries .. . have a key role to play in building and sustaining participatory and accountable democratic societies.").

309. Arlette Farge, The Allure of the Archives 123-24 (Thomas Scott-Railton trans., 2013). 
necessary? $?^{310}$

There is no answer to this question, which is no doubt why the GDPR explicitly provides that the RTBF should not apply "for archiving purposes in the public interest, scientific or historical research purposes" insofar as the RTBF "is likely to render impossible or seriously impair the achievement of the objectives of that processing." 311 It is striking that the GDPR does not include library archives in the derogation for "the right to freedom of expression and information, including processing for journalistic purposes and the purposes of academic, artistic or literary expression." 312 This is probably because it conceptualizes libraries as containing data to which the public is given access, rather than as institutions that actively communicate data to the public.

My intuition is that the CJEU will not interpret the GDPR to hold that Google is an archive assembled in the "public interest" or for "historical research purposes." Google's popularity, its commercialization, its hunger for the personal data of its users, ${ }^{313}$ all combine to make it seem far removed from the demure passivity associated with library archives. If libraries are conceptualized as making data available for public access, Google is much more easily imagined as deliberately communicating public information to the public. Although the Internet is rapidly fraying this distinction, it nevertheless underlies the GDPR's differentiation between derogations for expressive purposes and derogations for archives in the public interest.

The GDPR exempts historical archives because of deep social needs for common information. As one of the GDPR's most passionate advocates remarked, data privacy

is of course not an absolute right. There are cases where there is a legitimate and legally justified interest to keep data in a data base. The archives of a newspaper are a good example. It is clear that the right to be forgotten cannot amount to a right of the total erasure of

310. For a fascinating if unsuccessful effort to wrestle with this question, see IVAN SZEKELY, The Right To Be Forgotten and the New Archival Paradigm, in THE ETHICS OF MEMORY IN A Digital Age: Interrogating the Right To Be Forgotten 28, 28-49 (Alessia Ghezzi, Ăngela Guimarães Pereira \& Lucia Vesnić-Alujević eds., 2014). Cf. supra note 99.

311. GDPR, supra note 17 , art. 17(3).

312. Id. art. $85(1)$.

313. Grimmelmann, supra note 291 , at $941-43$. 
history. ${ }^{314}$

History is the common property of the public. No individual can be said to "control" 315 the personal data of history without unraveling the fabric of history itself. I cannot prevent you from narrating your account of historical events, even if they include information "relating to" 316 me. Nor can you prevent me from narrating my account of historical events, even if they include information "relating to" you. History is constructed from the interplay of such perspectives, including from the personal data contained within them. ${ }^{317}$ History requires that personal data become, as it were, common property, rather than under the "control" of particular data subjects. ${ }^{318}$

Democratic communication in the public sphere requires this same structure of common information. The public sphere is a field of intersubjective communicative action; it would collapse if individuals could at will withdraw from circulation information "relating to" themselves because they have the right to "control" such personal data. ${ }^{319}$ The public sphere in a democracy also serves the political purpose of self-governance. Those who control the circulation of

314. See Viviane Reding, The EU Data Protection Reform 2012: Making Europe the Standard Setter for Modern Data Protection Rules in the Digital Age, Address at the Innovation Conference Digital, Life, Design (Jan. 22, 2012) (emphasis omitted).

315. GDPR, supra note 17 , recital 7.

316. Directive, supra note 5, art. 2(a); GDPR, supra note 17, art. 4(1).

317. By contrast to Google Spain, the CJEU has been quite sensitive to the need for the circulation of shared information to preserve the "historical memory" of the actions of joint stock and limited liabilities companies as required by the First Council Directive 68/151/EEC of 9 March 1968, which emphasizes the need to co-ordinate "national provisions concerning disclosure" of the obligations of such companies "for the purpose of protecting the interests of third parties." Case C-398/15, Camera di Commercio, Industria, Artigianato e Agricoltura di Leece v. Manni, para. 4 (Mar. 9, 2017), http://curia.europa.eu/juris/document/document.jsf; jsessionid $=9$ ea $7 \mathrm{~d} 0 \mathrm{f} 130 \mathrm{~d} 5 \mathrm{da} 8068 \mathrm{~b} 3690 \mathrm{a} 4 \mathrm{e} 3 \mathrm{f} 94169 \mathrm{~d} 692 \mathrm{c} 409 \mathrm{ec} 6 . \mathrm{e} 34 \mathrm{KaxiLc3eQc40LaxqMbN} 4 \mathrm{PaN}$ iSe0?text $=$ \&docid $=188750$ \&pageIndex $=0$ \&doclang $=$ en\&mode $=$ Ist \&dir=\&occ $=$ first\&part $=1 \& \mathrm{cid}$ $=1193773$ [https://perma.cc/QRF8-ZW9L]; Directive 68/151/EEC of the First Council of the European Communities of 9 March 1968, 1968 O.J. (L65) 8. Although the disclosures required by Directive $68 / 151$ were inconsistent with the protections of personal data required by Directive 95/46, the CJEU nevertheless found the disclosures justified by the importance of reducing information costs in the interests of promoting marketplace efficiency and reliability.

318. Which is no doubt why courts have held that "it is not the role of judicial authorities to engage in rewriting history by ordering the removal from the public domain of all traces of" past publications. Case of Węgrzynowski \& Smolczewski v. Poland, App. No. 33846/07, para. 65 (Eur. Ct. H.R. July 16, 2013), http://hudoc.echr.coe.int/eng?i=001-122365 [https://perma.cc/A7CN52[7].

319. See, e.g., Dresbach v. Doubleday \& Co., 518 F. Supp. 1285, 1289-91 (D.D.C. 1981); Bonome v. Kaysen, No. 032767, 2004 WL 119731, at *3, *4 (Mass. Mar. 3, 2004); Anonsen v. Donahue, 857 S.W.2d 700, 705-06 (Tex. App. 1993). 
personal data in the public sphere control the creation of public opinion. Because personal data become relevant to public opinion as they become responsive to public curiosity, and because public curiosity is a variable and unpredictable phenomenon, it is impossible to "specify" in advance which personal data will become relevant to the formation of public opinion.

There is thus a fundamental tension between news, which orients the public by responding to public curiosity, and fair information practices, which demand previously articulated, explicit and specified purposes as a precondition for processing personal data. That is why both the Directive and the GDPR acknowledge derogations for journalistic activity, insofar as is necessary to accommodate freedom of expression, without specifying the contents of what constitutes such activity. ${ }^{320}$

320. The profound tension between fair information practices and news is very much on display in the Guidelines on the Implementation of Google Spain published by the Article 29 Data Protection Working Party ("Working Party"). ARTICLE 29 DATA PROT. WORKING PARTY, supra note 128, at paras. 4, 7. The Working Party was created pursuant to Article 29 of the Directive, which requires the creation of an advisory working party composed of representatives of each Member State to advise the European Commission on the implementation of the Directive. See Directive, supra note 5, art. 29. The Guidelines justify the distinction between the Google link and the original La Vanguardia website on the ground that:

[t]he processing carried out by the operator of a search engine is liable to affect significantly the fundamental rights to privacy and to the protection of personal data when the search by means of that engine is carried out on the basis of an individual's name, since that processing enables any internet user to obtain through the list of results a structured overview of the information relating to that individual that can be found on the internet-information which potentially concerns a vast number of aspects of his private life and which, without the search engine, could not have been interconnected or could have been only with great difficulty-and thereby to establish a more or less detailed profile of him. Furthermore, the effect of the interference with those rights of the data subject is heightened on account of the important role played by the internet and search engines in modern society, which render the information contained in such a list of results ubiquitous.

ARTICle 29 DAta Prot. Working PARTY, supra note 128, para. 4; see id. para. 7 ("The respective legal grounds of original publishers and search engines are different. . . Even when (continued) publication by the original publishers is lawful, the universal diffusion and accessibility of that information by objects of a search engine, together with other data related to the same individual, can be unlawful ....").

The Working Party correctly observes that using Internet search engines to comb the Internet for information based upon the names of data subjects instantly produces a vast amount of disparate personal data that is assembled in a single convenient form and costlessly distributed throughout the public sphere. From the perspective of a data subject who wishes to control her personal data, therefore, search engine results constitute a massive loss of control.

The reasoning of the Working Party nevertheless stands in stark contrast to the ultimate rationale of Google Spain. Google Spain dealt with the delisting of only a single link, which meant that it could implicitly incorporate the norms of Article 7 to determine whether the dissemination of information about Costeja's attachment proceedings was more "harmful" than was warranted 
The CJEU understood this problem in Google Spain, at least subconsciously, because it ultimately fashioned a doctrinal approach that lay outside the logic of the Directive. In the end, the CJEU balanced the seriousness of the Google link's invasion of privacy against the strength of the public's interest in the publication of the link. This is the structure of the right to be forgotten as it is applied by the courts of many countries, including the United States. ${ }^{321}$ This structure does not turn on empowering individuals "to maintain informational control" of their personal data, ${ }^{322}$ but instead seeks to identify how communications cause harm and how they contribute to public discourse.

Once it had entered the terrain of these questions, the CJEU might have concluded that the derogation for journalist purposes implied that the Directive did not apply to Google. ${ }^{323}$ In such

\begin{abstract}
by the public's interest in the disclosure of that information. Google Spain ultimately authorizes decisionmakers to weigh the privacy interests of a person in specific information against the public's interest in that information. But because the Working Party argues that legal harm flows from the aggregation of data, rather than from the content of any specific data point, it cannot analogously appeal to such context-specific Article 7 norms. The logic of the Working Party thus points inevitably to the conclusion that all searches on the names of data subjects are presumptively illegal unless overridden by some special public interest in receiving information under Article 11 of the Charter. Such public interests in receiving information would not attach to specific information, but would have to be abstractly and generically determined. Not only would this conclusion withdraw enormous quantities of information from the public sphere, but it would subordinate the circulation of such information to specified public interests as determined by courts or data protection agencies. This is exactly contrary to the logic of news, which provokes and responds to the actual curiosity of the demos and in that way embodies the logic of self-governance.
\end{abstract}

The premise of the Working Party that the aggregation of otherwise public data can constitute a significant breach of fair information practices is similar to that adopted by the U.S. Supreme Court in United States v. Reporters Committee for Freedom of the Press, 489 U.S. 749 (1989), in which the Court held that privacy concerns should prevent Freedom of Information Act requests from compelling the release of "rap sheets." Id. at 752. Although rap sheets compile only public information, consisting of a person's "history of arrests, charges, convictions, and incarcerations," the Court nevertheless concluded that there was a "distinction, in terms of personal privacy, between scattered disclosure of the bits of information contained in a rap sheet and the revelation of the rap sheet as a whole.... Plainly there is a vast difference between the public records that might be found after a diligent search of courthouse files, county archives, and local police stations throughout the country and a computerized summary located in a single clearinghouse of information." Id. at 752, 764. Reporters Committee for Freedom of the Press, however, did not address the suppression of information already circulating in the public sphere; it instead theorized criteria for releasing data into the public sphere.

321. See supra notes 33-41.

322. MAYER-SCHÖNBERGER, supra note 46 , at 135.

323. To this day many of the fair information practices required by the Directive are not in fact applied to Google. See Emmanouil Bougiakiotis, The Enforcement of the Google Spain Ruling, 24 INT'L J.L. \& INFO. TECH. 311, 316-17 (2016); Erdos, supra note 69, at 12-14. This is 
circumstances, any potential relief available to Costeja would have had to be based upon privacy concerns rooted in Article 7 of the Charter ${ }^{324}$ Following this logic would have required the CJEU to adopt a fully developed version of the right to be forgotten, which would necessarily draw on the elaborate jurisprudence of the ECtHR.

But the CJEU decided to pursue a different path. It concluded that although the instrumental logic of the Directive remained somehow still applicable to Google, the integrity of the public sphere could nevertheless be protected by superimposing on the Directive's narrow bureaucratic focus an abbreviated and rudimentary version of the right to be forgotten. This led to an opinion that was ambiguous about its sources and principles. It is not clear whether the issue in Google Spain was the improper processing of personal data or instead the inappropriate communication of potentially harmful information. It is not clear whether Google Spain sought to protect data privacy or dignitary privacy.

\section{B. Google Spain and the Right To Be Forgotten}

The difficulty is that the RTBF and the right to be forgotten cannot be coherently combined in this manner, for they are structured according to fundamentally disparate logics. At the most elementary level, the RTBF applies to a different unit of analysis than does the right to be forgotten. The RTBF focuses on data; the right to be forgotten focuses on discrete communicative acts. From the perspective of the right to be forgotten, harm to individuals does not come from the processing of personal data abstractly considered, but from communications that violate prevailing community customs and mores. The identical information can be communicated in ways that

especially true with respect to what the Directive and the GDPR designate as "special categories of data," see Directive, supra note 5, art. 8; GDPR, supra note 17, art. 9, which cannot be processed without consent, subject to certain explicit exceptions. Such data includes information regarding racial or ethnic origin, political opinions, religious beliefs, sexuality, and health. Whenever search engines produce results that process sensitive data, as they routinely do, their operations are presumptively illegal. Kulk \& Borgesius, supra note 6, at 27. "After the Google Spain judgment, Google, Data Protection Authorities, and courts have solved the sensitive data problem by ignoring it." $I d$. at 27-28. Just recently, however, the French Conseil d'Etat has referred to the CJEU a whole series of fundamental questions about the legality of Google links that reveal sensitive data. See DLA Piper, France's Highest Administrative Court Requests a Preliminary Ruling from the CJEU on the Right To Be Forgotten, LEXOLOGY (Mar. 13, 2017), http://www.lexology.com/library/detail.aspx?g=612b3b77-9e65-42c9-a01b-e040d323afee [https:// perma.cc/6RV5-PSEH].

324. For an example of how this might be operationalized, see de Mars \& O'Callaghan, supra note 278 , at $270-76$. 
are perfectly acceptable or in ways that are shocking and harmful. ${ }^{325}$ It may be humiliating to reveal the CT scan of a private person to the general public, but unobjectionable to provide it to a doctor for evaluation. ${ }^{326}$ In the context of the right to be forgotten, what matters is not the content of information, but the context and meaning of particular communicative acts. ${ }^{327}$

The RTBF and the right to be forgotten are accordingly composed of different elements. Discrete communicative acts, which are essential to the right to be forgotten, are irrelevant to the RTBF. The processing of personal data, which is essential to the RTBF, is not determinative for the right to be forgotten. The scope of the RTBF is defined by the managerial need to ensure the accuracy and relevance of personal data for the specific purposes for which they have been gathered. The scope of the right to be forgotten is defined by the contextual propriety of discrete communicative acts. Whereas the RTBF follows an instrumental logic of means and ends, the right to be forgotten follows a hermeneutic logic of social norms. Harm to personality is irrelevant to the application of the RTBF but is essential to the right to be forgotten.

The RTBF and the right to be forgotten flow from distinct perspectives on human sociality. The former is indifferent to social meaning; the latter turns on interpretations of social meaning. The former instantiates an abstract need for control; the latter seeks to maintain thick social practices and customs. The former imagines human beings as autonomous manipulators of data; the latter conceives human beings as socially constructed and dependent upon the observance of civil norms of respect. The former ignores the legitimate interests of the public; the latter seeks to identify and protect

325. NisSENBAUM, supra note 108, at 103-28; Post, supra note 106, at 978-87.

326. See Vassiliades v. Garfinckel's, Brooks Bros., 492 A.2d 580, 589-90 (D.C. 1985).

327. That is why the right to be forgotten assumes that communicating information to the public may be acceptable at time $T_{1}$, but may nevertheless become problematic at a subsequent time $\mathrm{T}_{2}$. Although the content of the communicated information may remain unchanged, the propriety of communicating that information may alter in the dimension of time. The importance of time was made explicit in 1939 in the comments to the RESTATEMENT (FIRST) OF TORTS (AM. LAW. INST. 1939), which affirmed that persons who at $T_{1}$ are deemed "objects of legitimate public interest" because of "the privileges which publishers have to satisfy the curiosity of the public as to their leaders, heroes, villains and victims," may, when "they have reverted to the lawful and unexciting life led by the great bulk of the community," no longer be objects of legitimate public interest. $I d$. $\$ 867 \mathrm{cmt}$. c. As one court put it, "there are timeliness or relatedness boundaries that circumscribe the breadth of public scrutiny to the incident of public interest." Toffoloni v. LFP Publ'g Grp., 534 F.3d 1201, 1210 (11th Cir. 2009). 
those interests. By seeking to layer these perspectives, one on top of the other, the CJEU created an opaque and indecipherable opinion. ${ }^{328}$

Let us assume, however, that despite the CJEU's long disquisition on the Directive, which seems to have misled many commentators, ${ }^{329}$ liability under Google Spain ultimately turns on some version of the right to be forgotten. In the end, the CJEU concluded that the harm to privacy caused by the Google link must be balanced against the public's interest in maintaining that link. On this assumption, what is most striking is the startling contrast between the CJEU's rudimentary description of this balance and the relatively sophisticated exposition of this same balance which may be found in the precedents of the ECtHR. ${ }^{330}$ The latter ought to have been pertinent to Google Spain because Article 7 of the Charter directly references Article 8 of the Convention. At a minimum, therefore, we may conclude that the CJEU did not fully appreciate the relevance of Article 7 to its own reasoning. ${ }^{331}$

It must be acknowledged that the CJEU did find its own way of recognizing both the harm to privacy caused by a particular communication and the public interest in allowing that communication, which constitute the two essential elements of the ECtHR's approach to the right to be forgotten. These two elements are also at the heart of the jurisprudence followed by American courts.

328. See EUROPEAN UNION COMM., supra note 26, at 21 (noting that the right to be forgotten created by Google Spain "is as elusive as the name is misleading").

329. See, e.g., Abramson, supra note 275, at 46 n.249; de Mars \& O'Callaghan, supra note 278, at 260; Internet Law-Protection of Personal Data-Court of Justice of the European Union Creates Presumption That Google Must Remove Links to Personal Data Upon Request, 128 HARV. L. REV. 735, 739 (2014) ("[T] he decision was a reasonable interpretation of the Directive's text and the deeply held privacy values manifested therein."); see also supra notes 62, 124 and accompanying text.

330. See, e.g., Case of Fürst-Pfeifer v. Austria, App. Nos. 33677/10, 52340/10 (Eur. Ct. H.R. May 17, 2016), http://hudoc.echr.coe.int/eng? $i=001-162864$ [https://perma.cc/MCM6-VU36]; Case of Satakunnan Markkinapörssi Oy \& Satamedia Oy v. Finland, App. No. 931/13 (Eur. Ct. H.R. July 21, 2015), http://hudoc.echr.coe.int/eng?i=001-156272 [https://perma.cc/P9JC-ZPE9]; Axel Springer AG v. Germany, App. No. 39954/08 (Eur. Ct. H.R. Feb. 7, 2012), http:// hudoc.echr.coe.int/eng?i=001-109034 [https://perma.cc/7F37-MUYA]; Eleni Frantziou, Further Developments in the Right To Be Forgotten: The European Court of Justice's Judgment in Case C131/12, Google Spain, SL, Google Inc. v. Agencia Espanola de Proteccion de Datos, 14 HuM. RTS. L. REV. 761, 772-75 (2014); Stefan Kulk \& Frederik Zuiderveen Borgesius, Freedom of Expression and 'Right to Be Forgotten' Cases in the Netherlands After Google Spain, 1 EuR. DATA PROT. L. REV. 113, 123 (2015).

331. See, e.g., Kulk \& Borgesius, supra note 6, at 21 ("[Google Spain] mainly applied the Data Protection Directive, and gave little attention to the extensive case law on balancing privacy and freedom of expression of the European Court of Human Rights."). 
Thus, the influential Restatement (Second) of Torts provides:

One who gives publicity to a matter concerning the private life of another is subject to liability to the other for invasion of his privacy, if the matter publicized is of a kind that

(a) would be highly offensive to a reasonable person, and

(b) is not of legitimate concern to the public. ${ }^{332}$

Following the Restatement, all American courts wrestling with the right to be forgotten evaluate both the offensiveness of a communication and its contribution to public discourse.

Well-socialized persons possess a more or less intuitive sense of when communications are offensive and threaten privacy, for they have internalized the social norms by which we judge such things. ${ }^{33}$ But it is methodologically puzzling how a court should determine whether a communication is "of legitimate concern to the public." American courts have sought to deflect this puzzle by interpreting the criterion of "legitimate concern to the public" in terms of the "newsworthiness" of a relevant communication. ${ }^{334}$

The criterion of "newsworthiness" invokes the history discussed in Part II of this Article. The story of news in the United States is that of a mass public successfully demanding the freedom to pursue its own curiosity rather than remaining under the tutelage of elite instruction. It also invokes the importance of news to maintaining the democratic public sphere, not because of the contents of any particular article, but because news as such incites and sustains widespread popular interest in common texts. ${ }^{335}$ These resonances render the criterion of "newsworthiness" so encompassing and so vague that it can frequently mean nothing more than what answers to the sheer curiosity of the public as determined by the very media outlets publishing the offending communication. ${ }^{336}$ American courts typically cede

332. RESTATEMENT (SECOND) OF TORTS § 652D (AM. LAW INST. 1965).

333. See Post, supra note 106, at 962-64.

334. Judge v. Saltz Plastic Surgery, P.C., 367 P.3d 1006, 1012-13 (Utah 2016); Shulman v. Grp. W Prods., Inc., 955 P.2d 469, 478-79 (Cal. 1998); Crump v. Beckley Newspapers, Inc., 320 S.E.2d 70,83 (W. Va. 1983).

335. The concept of "legitimate public concern" in American law has long been ambiguous, sometimes referring to what the public ought to know as informed democratic citizens, at other times referring to what the public in fact wishes to know, and yet at other times referring to the widely circulated information that constitutes the public as such. See Post, supra note 113, at $667-78$.

336. "The courts have recognized that public curiosity is a mysterious thing and frequently 


\section{"considerable deference to reporters and editors" in defining newsworthiness. ${ }^{337}$}

From this perspective, the criterion of "newsworthiness" comes close to a categorical judgment that whatever the press publishes is of legitimate public concern and hence insulated from liability. ${ }^{338}$ But American courts have never entirely relinquished the authority to impose "taste" and "judgment" upon the curiosity of the mass public:

concentrates most heavily on those least deserving of attention." Nizer, supra note 264, at 540 . American courts are cautious about making judgments about the substantive value of communications within the public sphere, holding that "[ [] he line between the informing and the entertaining is too elusive for the protection of that basic right [of freedom of speech]. Everyone is familiar with instances of propaganda through fiction. What is one man's amusement, teaches another's doctrine." Winters v. New York, 333 U.S. 507, 510 (1948). Refusing to identify which communications serve the public interest, the Court has declared:

Under our system of government there is an accommodation for the widest varieties of tastes and ideas. What is good literature, what has educational value, what is refined public information, what is good art, varies with individuals as it does from one generation to another... [A] requirement that literature or art conform to some norm prescribed by an official smacks of an ideology foreign to our system. . . From the multitude of competing offerings, the public will pick and choose. What seems to one to be trash may have for others fleeting or even enduring values.

Hannegan v. Esquire, Inc., 327 U.S. 146, 157-58 (1946). Drawing on the great American tradition of writing the news to invoke human interest and so to appeal to the "reveries" of readers, see supra note 171, Judge Hastie in the Third Circuit has drawn by far the most rigorous and eloquent conclusion with regard to the legal criterion of newsworthiness:

For present purposes news need be defined as comprehending no more than relatively current events such as in common experience are likely to be of public interest. In the verbal and graphic publication of news, it is clear that information and entertainment are not mutually exclusive categories. A large part of the matter which appears in newspapers and news magazines today is not published or read for the value or importance of the information it conveys. Some readers are attracted by shocking news. Others are titillated by sex in the news. Still others are entertained by news which has an incongruous or ironic aspect. Much news is in various ways amusing and for that reason of special interest to many people. Few newspapers or news magazines would long survive if they did not publish a substantial amount of news on the basis of entertainment value of one kind or another. This may be a disturbing commentary upon our civilization, but it is nonetheless a realistic picture of society which courts shaping new juristic concepts must take into account. In brief, once the character of an item as news is established, it is neither feasible nor desirable for a court to make a distinction between news for information and news for entertainment in determining the extent to which publication is privileged (footnotes omitted).

Jenkins v. Dell Pub. Co., 251 F.2d 447, 451 (3d Cir. 1958). The contrast to the top-down determination of the public interest implicit in Google Spain, as well as the Working Party's guidelines, could not be clearer.

337. Shulman, 955 P.2d at 485; see Diane Zimmerman, Requiem for a Heavyweight: $A$ Farewell to Warren and Brandeis's Privacy Tort, 68 CORNELL L. REV.291, 350-62 (1983).

338. See Harry Kalven, Jr., Privacy in Tort Law-Were Warren and Brandeis Wrong?, 31 L. \& CONTEMP. Probs. 326, 336 (1966). For a well-crafted argument that this judgment is unwarranted when the press fails to make expert judgments about what the public ought to know, see generally Erin C. Carroll, Making News: Balancing Newsworthiness and Privacy in the Age of Algorithms, GEO. L.J. (forthcoming). But see supra note 335. 
"Is the term 'newsworthy' a descriptive predicate, intended to refer to the fact there is widespread public interest? Or is it a value predicate, intended to indicate that the publication is a meritorious contribution and that the public's interest is praiseworthy?" A position at either extreme has unpalatable consequences. If "newsworthiness" is completely descriptive - if all coverage that sells papers or boosts ratings is deemed newsworthy -it would seem to swallow the publication of private facts tort, for "it would be difficult to suppose that publishers were in the habit of reporting occurrences of little interest." At the other extreme, if newsworthiness is viewed as a purely normative concept, the courts could become to an unacceptable degree editors of the news and self-appointed guardians of public taste...

The analysis of newsworthiness does involve courts to some degree in a normative assessment of the 'social value' of a publication. ${ }^{339}$

Because American courts lack authority to decree what the public should be interested in knowing, they tend to disguise judgments about "the 'social value' of a publication" by blending the criterion of newsworthiness with that of offensiveness. ${ }^{340}$ In the words of the Restatement (Second) of Torts:

In determining what is a matter of legitimate public interest, account must be taken of the customs and conventions of the community; and in the last analysis what is proper becomes a matter of community mores. The line is to be drawn when the publicity ceases to be the giving of information to which the public is entitled, and become a morbid and sensational prying into private lives for its own sake, with which a reasonable member of the public, with decent standards, would say that he had no concern. The limitations, in other words, are those of common decency, having due regard to the freedom of the press and its reasonable leeway to choose what it will tell the public,

339. Shulman, 955 P.2d at 481, 483-84 (citation omitted). Because of First Amendment concerns, Shulman was later reversed "at least with respect to information a publisher obtains from public (i.e. not sealed) official records of judicial proceedings." Gates v. Discovery Commc'ns, 101 P.3d 552, 554-55 (Cal. 2004). On the normative presuppositions underlying judgments of newsworthiness, see Daniel J. Solove, The Virtues of Knowing Less: Justifying Privacy Protections Against Disclosure, 53 DUKE L.J. 967, 1025 (2003).

340. "The two criteria, offensiveness and newsworthiness, are related. An individual, and more pertinently perhaps the community, is most offended by the publication of intimate personal facts when the community has no interest in them beyond the voyeuristic thrill of penetrating the wall of privacy that surrounds a stranger." Haynes v. Alfred A. Knopf, Inc., 8 F.3d 1222, 1232 (7th Cir. 1993). Contrast the reasoning of the Working Party, see supra note 320 , which jettisons any normative concept of harm and seeks to rely exclusively on a data subject's extensive loss of "control" over personal data and on official determinations of legitimate public interest. 
but also due regard to the feelings of the individual and the harm that will be done to him by the exposure. ${ }^{341}$

The difference between the right to be forgotten in the United States and the right to be forgotten in other legal systems is that American courts adopt an exceptionally strong presumption in favor of allowing publication. The United States is a uniquely heterogeneous and divided nation, ${ }^{342}$ perennially at odds with its own government. ${ }^{343}$ Its law extravagantly protects public discourse in the hope that unfettered public discussion may legitimize a vulnerable state in a diverse society with weak elites. ${ }^{344}$

Because American courts lack robust authority to determine what constitutes "legitimate" contributions to public discourse and to impose elite values on a mass public, they characteristically regard "the interest of the public in the free dissemination of the truth and unimpeded access to news" as "so broad, so difficult to define and so dangerous to circumscribe," that they "have been reluctant to make ... factually accurate public disclosures tortious, except where the lack of any meritorious public interest in the disclosure is very clear and its offensiveness to ordinary sensibilities is equally clear." ${ }^{345}$ This is enough to make the right to be forgotten a much diminished tort in the

341. Restatement (SECOND) OF TORTS $\$ 652 \mathrm{D} \mathrm{cmt.} \mathrm{h} \mathrm{(AM.} \mathrm{LAw} \mathrm{InST.} \mathrm{1977).} \mathrm{A} \mathrm{typical}$ judicial formulation is that:

[i]n determining whether a particular incident is 'newsworthy' and thus whether the privilege shields its truthful publication from liability, the courts consider a variety of factors, including the social value of the facts published, the depth of the article's intrusion into ostensibly private affairs, and the extent to which the party voluntarily acceded to a position of public notoriety.

Kapellas v. Kofman, 540 P.2d 912, 922 (Cal. 1969).

342. In a nation as diverse as the United States, "what is 'private' so as to make its publication offensive likely differs among communities, between generations, and among ethnic, religious, or other social groups, as well as among individuals. Likewise, one reader's or viewer's 'news' is another's tedium or trivia." Anderson v. Fisher Broad. Cos., 712 P.2d 803, 809 (Or. 1986).

343. One implication of heterogeneity in the United States is that our public sphere is the site of continual contest about the appropriate norms that should define privacy. Those who live in mansions and those who live in boarding houses differ on this question, see supra notes 240-46 and accompanying text, so American courts have tended to interpret our First Amendment to require neutrality in this "marketplace of communities." Post, supra note 113, at 632. Sometimes when upholding freedom of speech, European courts will also adopt this kind of pluralist idiom. See, e.g., Kaperzyński v, Poland, App. No. $43206 / 07$ (Eur. Cl. H.R. Apr. 3, 2012), http:/ hudoc.echr.coe.int/eng?i=001-110171 [https://perma.cc/M3CW-77AF]. But for the most part European courts have much less difficulty subordinating the public sphere to community norms that they regard as authoritative. See infra note 350.

344. Post, supra note 106, at 989-90.

345. Jenkins v. Dell Pub. Co., 251 F.2d 447, 450 (3d Cir. 1958). 
United States, ${ }^{346}$ surfacing only in "extreme cases" 347 as measured by the extraordinary offensiveness of a publication. ${ }^{348}$ It is possible that the tort may not even survive under current First Amendment doctrine. ${ }^{349}$

Other legal systems construct this balance between privacy and freedom of public discussion differently. They are far less deferential

346. Samantha Barbas, The Death of the Public Disclosure Tort: A Historical Perspective, 22 YAlE J.L. \& HuM. 171, 172-73 (2010); Linda N. Woito \& Patrick McNulty, The Privacy Disclosure Tort and the First Amendment: Should the Community Decide Newsworthiness, 64 IOWA L. REV. 185, 186 (1979). The American press "is freer to invade personal privacy than perhaps any other in the world." Samantha Barbas, The Sidis Case and the Origins of Modern Privacy Law, 36 COLUM. J.L. \& ARTS 21, 22 (2012); Neil Richards, The Limits of Tort Privacy, 9 J. TeleCOMm. \& High TECH. L. 357, 378-79, 382 (2011). But see Amy Gajda, Judging Journalism: The Turn Towards Privacy and Judicial Regulation of the Press, 97 CALIF. L. REv. 1039, 1041-42 (2009) (purporting to find a modern trend to hold journalists accountable).

347. Shulman v. Grp. W. Prods., Inc., 955 P.2d 469, 485 (Cal. 1998); see Bennett, supra note 39 , at 171 .

348. So, for example, in the recent and much publicized case of Bollea v. Gawker, $913 \mathrm{~F}$. Supp. 2d 1325 (M.D. Fla. 2012), in which professional wrestler Hulk Hogan sued for invasion of privacy because of Gawker's airing of a video of him having sex with a friend's wife, see Complaint at 12 13, Bollea v. Gawker, 913 F. Supp. 2d (M.D. Fla. 2012) (No. 12012447-CI-011), a major defense witness was forced to concede that elements of the story were not newsworthy. See Letitia Stein, Gawker Editor Admits Limit to News Value at Hulk Hogan Sex-Tape Trial, REUTERs (Mar. 14, 2016), http://www.reuters.com/article/us-people-hulkhogan-idUSKCN0WG1A5 [https://perma. cc/C47A-J5E2]. The ultimate verdict of approximately $\$ 140$ million drove Gawker into bankruptcy. See Paul Farhi, Gawker Files for Chapter 11 Bankruptcy Protection, WASH. PoST (June 10, 2016), https://www.washingtonpost.com/lifestyle/style/gawker-files-for-chapter-11bankruptcy-protection/2016/06/10/45ef7420-2f2e-11e6-9b37-42985f6a265c_story.html

[https://perma.cc/HML7-JC25]; Nick Madigan, Jury Tacks on \$25 Million to Gawker's Bill in Hulk Hogan Case, N.Y. Times (Mar. 21, 2016), http:/www.nytimes.com/2016/03/22/business/ media/hulk-hogan-damages-25-million-gawker-case.html?_r=0 [https://perma.cc/X3ZH-9E97]; Peter Sterne, Jury Awards Hulk Hogan $\$ 115$ Million as Gawker Looks To Appeal, PoLITICO (Mar. 18, 2016), http:/www.politico.com/media/story/2016/03/jury-awards-hulk-hogan-115million-as-gawker-looks-to-appeal-004433 [https://perma.cc/7WGQ-QLDC].

349. See Gates v. Discovery Commc'ns, 101 P.3d 552, 554-55 (Cal. 2004). But see Wolfe v. Schaefer, 619 F.3d 782, 785-86 (7th Cir. 2010); Amy Gajda, The Present of Newsworthiness, 50 N.E. L. REV. 145 (2016) $(147,163)$ (noting a trend in modern jurisprudence to hold journalists accountable); Amy Gajda, Privacy, Press, and a Right To Be Forgotten in the United States (May 29, 2017) (unpublished manuscript) (on file with the Duke Law Journal). I should note that the U.S. Supreme Court has been surprisingly careful to impose First Amendment restraints on privacy protections in a manner that more or less resolves each case only as it arises "in a discrete factual context." Florida Star v. B.J.F., 491 U.S. 524, 530 (1989); see Bartnicki v. Vopper, 532 U.S. 514, 524-33 (2001); Smith v. Daily Mail Pub. Co., 443 U.S. 97, 104-05 (1979) (holding that the press cannot be held liable for publishing the identity of a juvenile defendant when that identity has been "lawfully obtained, ... except when necessary to further an interest more substantial than is present here."); Cox Broad. Corp. v. Cohn, 420 U.S. 469, 491 (1975) ("Rather than address the broader question whether truthful publications may ever be subjected to civil or criminal liability consistently with the First and Fourteenth Amendments ... it is appropriate to focus on the narrower interface between press and privacy that this case presents."). 
to the curiosity of the public ${ }^{350}$ and far more sympathetic to the value of privacy. ${ }^{351}$ It is not now my concern to determine a single, correct solution to this balance. My effort is instead to explore how the normative logic presupposed by the right to be forgotten should have been applied in Google Spain if the CJEU had been committed to balancing Costeja's privacy interests against the value of public discourse. I am interested in how Google Spain might have interpreted the right to be forgotten if it had not been mesmerized by some ambiguous combination of the RTBF and the right to be forgotten.

Unlike the RTBF, the right to be forgotten applies strictly to communicative acts, and the communicative act at issue in Google Spain was the link to the La Vanguardia website. At the simplest level, therefore, the CJEU should have asked, first, whether the publication of the Google link was harmful and offensive. If the answer to this question was affirmative, the CJEU should have asked, second, whether the Google link was of legitimate concern to the public. This is a pretty flat-footed formulation of the issues underlying the right to be forgotten, but it is sufficient to illustrate that the first question is all but unintelligible. Google aspires to make all websites available to every reader. Any given link is accordingly stripped of the narrative properties, the human meaning, that might render it either offensive or inoffensive. ${ }^{352}$ To take offense at a Google link is like being outraged

350. See, e.g., Case of Aleksey Ovchinnikov v. Russia, App. No. 24061/04, para. 50 (Eur. Ct. H.R. Dec. 16, 2010), http://hudoc.echr.coe.int/eng?i=001-102322 [https:/perma.cc/8WMX-4R5V] ("The Court reiterates in this connection that in cases of publications relating the details of an individual's private life with the sole purpose of satisfying the curiosity of a particular readership, the individual's right to the effective protection of his or her private life prevails over the journalist's freedom of expression. The Court must therefore determine whether the articles authored by the applicant made a contribution to a debate of general interest to society."); Von Hannover v. Germany, 2004-VI Eur. Ct. H.R. paras. 41, 70 ("[T] publication of the photos and articles in question, the sole purpose of which was to satisfy the curiosity of a particular readership regarding the details of the applicant's private life, cannot be deemed to contribute to any debate of general interest to society despite the applicant being known to the public."); A\&B v. Ediciones El País SL, S.T.S., Oct. 15, 2015 (R.J., No. 545, 16 ) (Spain) (distinguishing between curiosity justified by public interest and curiosity aroused by "el gusto por el cotilleo y la maledicencia [gossip and evil-speaking]").

351. Case of Biriuk v. Lithuania, App No. 23373/03, para. 38 (Eur. Ct. H.R. Nov. 25, 2008), http:/hudoc.echr.coe.int/eng?i=001-89827 [https:/perma.cc/G7LL-3735]; Tammer v. Estonia, 2001-I Eur. Ct. H.R. paras. 263, 280-81. On the confidence of European courts to balance dignity and privacy against freedom of speech, see Ronald J. Krotoszynski, Jr., Reconciling Privacy and Speech in the Era of Big Data: A Comparative Analysis, 56 WM. \& MARY L. REV. 1279, 1314-26 (2015).

352. There may be a possible exception in terms of the order in which the link appears in response to a Google search. The order may carry narrative meaning, because items that appear near the top of the search results may be taken to be more significant. The logic I am advancing 
by the vacuum cleaner that sweeps up a lost earring.

The second question seems equally vacuous. Insofar as newsworthiness is determined by the "customs and conventions of the community," Google links seem merely blank. ${ }^{353}$ They are neither more nor less "morbid or sensational" than a library card that refers to a morbid and sensational novel. If Google links are of legitimate concern to the public, it is because of the systemic properties of the Google search engine, which, like the media or the press, brings news to the contemporary reader.

By contrast, no such difficulties apply to the La Vanguardia website, which contains an article whose propriety and newsworthiness can be assessed in the usual manner. It is intelligible to ask whether the website offends propriety by continuing to publish the announcement of Costeja's attachment proceedings more than a decade after they had transpired. It is intelligible to ask whether the La Vanguardia website is about a matter that is now newsworthy or of legitimate concern to the public. We may differ in our answers to these inquiries, but at least we share some idea what the questions mean.

The logic of social norms thus points toward evaluating the legality of the Google link in light of the propriety of the La Vanguardia website. $^{354}$ The primary source of legal dignitary harm is the $L a$ Vanguardia website, and therefore legal attention ought primarily be directed to that website. ${ }^{355}$ If it were to be found that the website violated the right to be forgotten, remedies might include anonymization. ${ }^{356}$ This seems to be the approach of the Belgium Court of Cassation, which in April 2016 decided that the RTBF required the anonymization of an article in the archives of Le Soir that had been

in text may also not apply when Google distributes images rather than text. Images may carry a far thicker narrative meaning than a link.

353. Again, this reasoning may not apply in the case of Google's distribution of images, as distinct from simple links. See supra note 352.

354. Google Spain, supra note 12, paras. 82-83; see Juliane Kokott \& Christoph Sobotta, The Distinction Between Privacy and Data Protection in the Jurisprudence of the ECJ and the ECtHR, in DATA PROTECTION ANNO 2014: HOW TO RESTORE TRUST?: CONTRIBUTIONS IN HONOUR OF PETER HustinX 90, 93 (Hielke Hijmans \& Herke Kraneborg eds., 2014) ("[A]ny potential interference with the right to privacy would not result from Google's service, but from publication of the information by the newspaper.").

355. Thus, in the wake of Google Spain, European Data Protection Agencies, "as well as the Council of Europe, suggest approaching the source as a useful first step in practice." Aleksandra Kuczerawy \& Jef Ausloos, From Notice-and-Takedown to Notice-and-Delist: Implementing Google Spain, 14 COL. TECH. L.J. 219, 237 (2016); see supra JoNES, note 43, at 151-52.

356. See, e.g., Briscoe v. Reader's Digest Ass'n, 483 P.2d 34, 41 (Cal. 1971). 
digitized and placed online. ${ }^{357}$ Remedies might also include the mandatory use of robots exclusion standards to prevent search engines from indexing a website. Thus the Spanish Supreme Court implemented the RTBF established by Google Spain by requiring Spain's national newspaper to use such standards to prevent online search engines from indexing an article discussing two individuals' participation in drug crimes during the 1980 s. ${ }^{358}$

If it were to be found that the La Vanguardia website did not violate the right to be forgotten, we should ask whether a Google link to the website might nevertheless independently violate the right to be forgotten. Google Spain seemingly adopts this option. It does so on the ground that a Google link makes access to the underlying website "appreciably easier for any internet user making a search in respect of the person concerned" and that it therefore "may play a decisive role in the dissemination of that information" and "constitute a more significant interference with the data subject's fundamental right to privacy than the publication on the web page." 359

Essentially, the CJEU argues that Costeja was more significantly harmed because the Google link more widely circulated the $L a$ Vanguardia website. But this reasoning makes sense only if we

357. Hugh Tomlinson, Case Law, Belgium: Olivier G v Le Soir. "Right To Be Forgotten" Requires Anonymisation of Online Newspaper Archive, INFORRM's BLOG, https:// inforrm. wordpress.com/2016/07/19/case-law-belgium-olivier-g-v-le-soir-right-to-be-forgotten-requiresanonymisation-of-online-newspaper-archive-hugh-tomlinson-qc [https://perma.cc/MH9AVQAW]. I use the term RTBF rather than "right to be forgotten" because the case was decided under Article 8 of the Charter. This has very troubling implications. Although both the Directive and the GDPR contain exceptions for journalistic purposes, Article 8 contains no such exemption. This cleanly illustrates the contrast between the right to be forgotten and the RTBF. Because the RTBF applies to data processing, it equally encompasses newspaper filing systems and newspaper digital publications. But because the logic of social norms applies to communication rather than to information, the right to be forgotten applies only to newspaper communications. The potential application of the fair information practices of Article 8 to newspaper filing systems is a truly fearsome possibility.

358. A\&B v. Ediciones El País SL, S.T.S., Oct. 15, 2015 (R.J., No. 545) (Spain); see PHAEDRA II, The SPANISH SuPREME COURT ReQuires THE SCOPE OF THE "RIGHT TO OBLIVION" AGAINST THE MEDIA (2015), http://www.phaedra-project.eu/wp-content/uploads/ PHAEDRA-II_SP_AEPD_Right-to-be-forgotten_UJI_November2015.pdf [https://perma.cc/ W7SQ-5VQ3]; Hugh Tomlinson, Case Law, Spain: A and B v Ediciones El País, Newspaper Archive To Be Hidden from Internet Searches but No "Re-Writing of History," INFORRM'S BLOG, https:/inforrm.wordpress.com/2015/11/19/case-law-spain-a-and-b-v-ediciones-el-paisnewspaper-archive-to-be-hidden-from-internet-searches-but-no-re-writing-of-history-hughtomlinson-qc [https://perma.cc/6U4K-Y2BU]. El Pats was not required to remove the articles from its own internal archive nor to de-index them from their own website's internal search engine.

359. Google Spain, supra note 12, para. 87. 
presuppose that the La Vanguardia website itself inflicts a legally cognizable dignitary harm, which is contrary to our original assumption. No doubt if the La Vanguardia website does inflict a legally cognizable harm, we would be justified in curtailing its distribution by Google, although a full and complete remedy ought to be addressed to the website itself. But if we assume that the website does not independently inflict a legally cognizable harm, there is no justification for curtailing its circulation by requiring Google to delist it. ${ }^{360}$

Under the logic of social norms, moreover, it seems highly unlikely that the Google link will be found to violate the right to be forgotten independently of the La Vanguardia website. Both the Google link and the La Vanguardia website contain the same information. Each offers that information to the "indefinite number of people" 361 that constitute the general public in the context of the Internet. Each is of exactly the same concern to the public. The very blankness of a Google link means that it will almost always assume the normative coloring of the website to which it points. If it makes any sense at all to characterize the Google link as an inappropriate communication, it must stand or fall together with the La Vanguardia website.

The logic of social norms thus suggests that Google Spain was misguided in seeking to separate the Google link from the $L a$

360. It might be argued that the Google link enables the La Vanguardia website to meet the "publicity" condition enunciated by the Second Restatement. RESTATEMENT (SECOND) OF TORTS $\S 652 \mathrm{D} \mathrm{cmt.} \mathrm{h} \mathrm{(AM.} \mathrm{LAW} \mathrm{INST.} \mathrm{1977).} \mathrm{Unlike} \mathrm{the} \mathrm{much} \mathrm{older} \mathrm{torts} \mathrm{of} \mathrm{libel} \mathrm{and} \mathrm{slander,} \mathrm{the}$ tort of invasion of privacy developed-at least in the United States - in response to the intrusions of the mass media. As a consequence, the tort imposes liability only when someone gives "publicity" to private facts. There is no liability if private information is communicated only to small numbers of people. The best explanation for the publicity requirement is that the law aims to impose civility within the public sphere without dampening the spontaneous and affective communication characteristic of the private sphere. See Post, supra note 106, at $987-95$ (discussing the publicity requirement and the cases that have applied it). It might be argued that whereas a Google link "publicizes" a website, the La Vanguardia website by itself cannot "publicize" personal data about Costeja. It would follow from this argument that Google can be required to erase the link to the La Vanguardia website, but that the La Vanguardia website need not be removed from the Internet. The difficulty with this argument, however, is that there is no doubt that under any contemporary understanding of the tort, the La Vanguardia website already gives "publicity" to Costeja's personal data. It is addressed to the public sphere, just as Google is addressed to the public sphere. Moreover, using the "publicity requirement" to distinguish between Google and the La Vanguardia website does not accomplish the underlying normative purpose of the requirement. There is no expectation that insulating the La Vanguardia from the reach of tort liability will preserve a realm of spontaneous and affective communication.

361. Case C-101/01, Criminal Proceedings Against Bodil Lindqvist, 2003 E.C.R. I-12971 to I13014, para. 47 (2003). 
Vanguardia website. If the latter violates the right to be forgotten, the cleanest and most appropriate remedy is to address the website itself. ${ }^{362}$ But if the La Vanguardia website does not violate the right to be forgotten, the Google link ought not be liable, and it does not matter whether it increases the circulation of the La Vanguardia website. The wide circulation of the Google link is irrelevant if the link is deemed newsworthy and not offensive, as ought to be the case if the $L a$ Vanguardia website is found to be newsworthy and not offensive.

The CJEU's effort to separate the Google link from the $L a$ Vanguardia website causes important and undesirable consequences. As a result of Google Spain, members of the public can still learn about what happened to Costeja, but they must pay a much greater price to do so. Google Spain essentially increases the cost of accessing information about Costeja's financial difficulties. Although members of the public can no longer search on Costeja's name, they can still learn about his attachment proceedings if they search public records, or creatively design new forms of Google searches that do not use his name, or inspect printed copies of La Vanguardia's archive. ${ }^{363}$ All this costs extra time and money.

The architecture created by Google Spain thus skews the distribution of information toward those with resources to spend on information acquisition. ${ }^{364}$ This is surely an odd consequence for a society that celebrates open and equal access to information. ${ }^{365} \mathrm{It}$ is one thing for a legal system to decide that certain information should not be made publicly available; it is quite another deliberately to create a system in which that same information is made available only to those wealthy enough to obtain it. ${ }^{366}$ Google Spain does not withdraw

362. Of course, anonymizing the original website may have more drastic informational effects than merely delisting it, but this simply makes apparent the stakes in the decision to delist, because "if certain search results are hidden or removed from search results, this has much the same effect as deleting the original content." Letter from Gerald Leitner, Secretary-General of International Federation of Library Associations and Institutions, on Application of Right To Be Forgotten Rulings: The Library Viewpoint (Oct. 24, 2016), http:/www.ifla.org/files/assets/faife/statements/ 161024_ifla_on_rtbf_case_in_france.pdf [https://perma.cc/AY2A-UQHA].

363. Hoffman et al., supra note 98 , at 458 ("The result is . . much more about obscurity than it is about a right to be forgotten. The ruling has the effect of obscuring information from searches solely based on a name....").

364. See Pablo Salvador Coderch, Entre Recordar y Olvidar [In Between Remembering and Forgetting], EL PAÍs (June 1, 2011), http://elpais.com/diario/2011/06/01/opinion/1306879205_85 0215.html [https://perma.cc/36ZF-M3NB].

365. See supra note 307.

366. I am reminded of the opposition of John Imray of Aberdeen to the creation of a public library service in Great Britain on the ground that it would raise "the lower classes too highly by 
personal data from the public sphere; it taxes those who wish to access that data in the public sphere.

By separating the status of the Google link from that of the $L a$ Vanguardia website, the CJEU also creates an additional and serious problem of institutional design. As best I can make out, the CJEU believed that it could enforce the RTBF on the cheap by giving data subjects the right to demand from Google as a data controller "the rectification, erasure or blocking of data the processing of which does not comply with the provisions of [the Directive]." 367 The CJEU apparently believed that a large and wealthy corporation like Google could bear the cost of creating the procedures necessary to resolve the hundreds of thousands of predictable RTBF claims. ${ }^{368}$

The CJEU was correct in its expectations insofar as the vast majority of RTBF complaints are presently pending before Google itself. But it has been widely observed that this structure of enforcement is deeply flawed because it leaves important decisions about freedom of expression in the hands of an unaccountable private company with strong financial incentives to err on the side of censorship. ${ }^{369}$ If the legal status of Google links were tied to the

giving them information and that it is better to keep them without it." MURISON, supra note 301, at 16.

367. Google Spain, supra note 12, para. 70; see Factsheet on the "Right to be Forgotten" Ruling (C-131/12), supra note 62.

368. The structure of the system created by Google Spain is in some ways analogous to the notice and take-down provisions established by the E-Commerce Directive. Council Directive 2000/31EC, 2000 O.J. (L 178), http://eur-lex.europa.eu/LexUriServ/LexUriServ.do? uri=CELEX: 32000L0031:en:HTML [https://perma.cc/4NF3-QBJF]; see Stefan Kulk \& Frederik Zuiderveen Borgesius, Google Spain v. González: Did the Court Forget About Freedom of Expression?, 5 EUR. J. RISK REG. 389, 492 (2014).

369. Bougiakiotis, supra note 323, at 322-24; LoCascio, supra note 41; Daphne Keller, The Final Draft of Europe's "Right to be Forgotten" Law, CrR. FOR INTERNET \& SOC'Y (Dec. 17, 2015), http://cyberlaw.stanford.edu/blog/2015/12/final-draft-europes-right-be-forgotten-law [https://perma.cc/4TVL-EF83] ("Intermediaries that do not honor RTBF requests risk crippling fines. There are no legal consequences for 'over-removing' content targeted by invalid RTBF requests."). Commentators have noted that:

the court's guidance in that case is so vague that it leaves much room for interpretation about which types of removal requests should be granted, and which should not. This puts a heavy responsibility on the companies affected by the ruling to exercise careful and difficult balancing acts between one person's privacy rights and the rights of others to receive and impart information. Companies face pressures to minimise costs and maximise revenues, and there is a powerful incentive to accommodate too many requests, removing too much content, rather than taking on costly and risky lawsuits and legal challenges.

Jens-Henrik Jeppesen \& Emma Llans6, EU's "Right to be Forgotten" Policy Sets Bad Precedent for Free Expression Worldwide, CDT (Feb. 11, 2016), https://cdt.org/blog/eus-right-to-be-forgot ten-policy-sets-bad-precedent-for-free-expression-worldwide/ [https://perma.cc/NS9K-5ZQT]. 
websites to which they refer, however, and if appropriate remedies were to be understood as primarily addressed to those websites, there would be no justification for privatizing the enforcement of the RTBF in this manner. This is because only a public legal system can possess the necessary authority to take down or modify original websites. ${ }^{370}$

There is no doubt that Google Spain did succeed in fashioning a powerful and effective instrument for controlling the circulation of information on the web. By targeting the search engines that serve as the gateways for that circulation, the CJEU has created a cheap and comprehensive method for dampening the flow of personal data. But it is not clear what the CJEU has accomplished by controlling the flow of data in this way. It has produced a remedy that is comprehensible neither within the instrumental logic of the Directive, which does not contain concepts of harm or of the public interest, nor within the normative logic of the right to be forgotten, which would not separate Google from its underlying websites. It is uncertain what the CJEU was striving to accomplish by the strange RTBF it has cobbled together.

By privatizing the enforcement of the RTBF through Google, moreover, the CJEU has virtually guaranteed that the axiological ambiguity will continue. We know that Google has set up a distinguished Advisory Council to propose guidelines for implementing the mandate of Google Spain, and we know that the Council has proposed an elaborate "balancing test to determine

On the substantial economic penalties imposed by the GDPR for non-compliance, see GDPR, supra note 17 , arts. 53,83 .

370. The Advocate General in Google Spain voiced this very concern, stating:

[I] would also discourage the Court from concluding that these conflicting interests could satisfactorily be balanced in individual cases on a case-by-case basis, with the judgment to be left to the internet search engine service provider. Such "notice and take down procedures", if required by the Court, are likely either to lead to the automatic withdrawal of links to any objected contents or to an unmanageable number of requests handled by the most popular and important internet search engine service providers. In this context it is necessary to recall that "notice and take down procedures" that appear in the ecommerce Directive 2000/31 relate to unlawful content, but in the context of the case at hand we are faced with a request for suppressing legitimate and legal information that has entered the public sphere.

In particular, internet search engine service providers should not be saddled with such an obligation. This would entail an interference with the freedom of expression of the publisher of the web page, who would not enjoy adequate legal protection in such a situation, any unregulated "notice and take down procedure" being a private matter between the data subject and the search engine service provider. It would amount to the censuring of his published content by a private party. It is a completely different thing that the States have positive obligations to provide an effective remedy against the publisher infringing the right to private life, which in the context of internet would concern the publisher of the web page.

See Opinion of Advocate General Jääskinen, Google Spain SL v. Agencia Española de Protección de Datos, 2013 E.C.R. 424, paras. 133, 134; JONES, supra note 43, at 179. 
whether the data protection rights of the data subject are outweighed by 'the preponderant interest of the general public in having, on account of inclusion in the list of results, access to the information in question." "'371 We know that Google Spain has encouraged massive numbers of requests for Google to delist links on the basis of the RTBF. ${ }^{372}$ But because Google's adjudicative processes remain behind closed doors, because we cannot ascertain what tests Google is actually applying to what circumstances and in what ways, ${ }^{373}$ the actual values that underlie the RTBF created by Google Spain remain obscure. ${ }^{374}$

Eighty Internet scholars evaluating Google's implementation of the RTBF have concluded that "[b]eyond anecdote, we know very little about what kind and quantity of information is being delisted from search results, what sources are being delisted and on what scale, [and] what kinds of requests fail and in what proportion." ${ }^{375}$ The experts also

371. Luciano Floridi et al., Advisory COUNCIL TO GOOGLE ON THE Right TO BE FORGOTTEN 5-6 (Feb. 6, 2015) https:/static.googleusercontent.com/media/archive.google.com/ en//advisorycouncil/advisement/advisory-report.pdf [https://perma.cc/UT7Q-Y64V] .

372. See supra note 22.

373. Kuczerawy \& Ausloos, supra note 355, at 244-46.

374. Curiously, European data authorities seem intent to ensure that Google not routinely inform webmasters when pages from their sites are removed pursuant to take down requests under the Directive. The Working Party said:

No provision in EU data protection law obliges search engines to communicate to original webmasters that results relating to their content have been de-listed. Such a communication is in many cases a processing of personal data and, as such, requires a proper legal ground in order to be legitimate. No legal ground can be found in Article 7 of Directive $95 / 46 / \mathrm{EC}$ to routinely communicate de-listing decisions to primary controllers.

On the other hand, it may be legitimate for search engines to contact original publishers prior to any decision about a de-listing request, in particularly difficult cases, when it is necessary to get a fuller understanding about the circumstances of the case. In those cases, search engines should take all necessary measures to properly safeguard the rights of the affected data subject.

ARTICle 29 DATA PROT. WORKING PARTY, supra note 128, para. 23.

Google has even been penalized for notifying a webmaster about a delisting. See Agencia Española de Protección de Datos, Resolución: R/02232/2016, http:/www.agpd.es/portalweb AGPD/resoluciones/procedimientos_sancionadores/ps_2016/common/pdfs/PS-00149-2016_

Resolucion-de-fecha-14-09-2016_Art-ii-culo-10-16-LOPD.pdf [https://perma.cc/ZJ78-R866]. If delisted websites cannot know about Google's decision to delist them, and hence cannot appeal that decision, Google's application of its right to be forgotten policy will necessarily be skewed in lavor of delisting. The parameters of the policy will remain publicly uncontested and hence opaque. For a superb discussion of an appropriate procedural framework for RTBF requests under both the Directive and the GDPR, which takes account of Google's status as an intermediary, see Daphne Keller, The Right Tools: Europe's Intermediary Liability Laws and the 2016 General Data Protection Regulation, 31 BERKELEY TECH. L.J. (forthcoming 2018) (manuscript at 37-57), https://papers.ssrn.com/sol3/ papers.cfm?abstract_id=2914684 [https:// perma.cc/32WN-MRQP].

375. Jef Ausloos et al., Open Letter to Google from 80 Internet Scholars: Release RTBF 
worried that the public did not know "Google's guidelines in striking the balance between individual privacy and freedom of expression interests." $" 376$

Google Spain has thus stitched together a Frankenstein - a blind creation that interferes with the public sphere in unaccountable ways to unaccountable ends. It may dampen the circulation of personal data, but whether it serves defensible public purposes is an open question.

\section{CONCLUSION}

Facebook founder Mark Zuckerberg created a storm when he was understood to announce in 2010 "that privacy was no longer a 'social norm." "'377 What he actually said was far more reasonable: "People have really gotten comfortable not only sharing more information and different kinds, but more openly and with more people. That social norm is just something that has evolved over time." 378 What aroused anger and distrust was Facebook's considerable agency in affecting the evolution of privacy norms in directions that seem to correspond to Facebook's own financial interests. ${ }^{379}$

Privacy norms are in fact unstable and uncertain in a rapidly developing digital world. ${ }^{380}$ There is room for suspicion about how influential actors like Facebook seek to shape the development of these norms. But this suspicion ought not to blind us to the emergence of a virtual public sphere that is of enormous contemporary

Compliance Data, MEDIUM (May 13, 2015), https://medium.com/@ellgood/open-letter-to-googlefrom-80-internet-scholars-release-rtbf-compliance-data-cbfc6d59f1bd\#.2x79b0bs6

[https://perma.cc/T2L9-HXT5].

376. Id.

377. Bobbie Johnson, Privacy No Longer a Social Norm, Says Facebook Founder, GuARDIAN (Jan. 10, 2010), https:/www.theguardian.com/technology/2010/jan/11/faccbookprivacy [https://perma.cc/NMN3-SVYJ]; see, e.g., Marshall Kirkpatrick, Facebook's Zuckerburg Says the Age of Privacy is Over, READWRITE (Jan. 9, 2010), http://readwrite.com/2010/01/ 09/facebooks_zuckerberg_says_the_age_of_privacy_is_ov [https://perma.cc/B3K6-KR5U]. Facebook and Zuckerberg were eventually forced to beat a hasty retreat. See, e.g., Will Oremus, Facebook's Privacy Pivot, SLATE (July 25, 2014), http:/www.slate.com/articles/technology/ future_tense/2014/07/facebook_s_privacy_pivot_mark_zuckerberg_s_plan_to_win_back_trust.ht $\mathrm{ml}$ [https://perma.cc/T53R-Q6FT].

378. Ann Cavoukian, Privacy Is Still a Social Norm, Globe \& MAIL (Aug. 23, 2012), http:/www.theglobeandmail.com/opinion/privacy-is-still-a-social-norm/article1209523/ [https:/] perma.cc/3REL-K7DF].

379. Kirkpatrick, supra note 377 ("I don't buy Zuckerberg's argument that Facebook is now only reflecting the changes that society is undergoing. I think Facebook itself is a major agent of social change and by acting otherwise Zuckerberg is being arrogant and condescending.").

380. Schwartz, supra note 306 , at $1442-43$. 
significance and that is sustained by an infrastructure of search engines like Google. That Google is a profit-making corporation no more compromises its role in sustaining this public sphere than it compromised the role of profit-seeking, nineteenth-century newspapers.

The point is implicitly acknowledged by the CJEU in Google Spain. It seems to understand that the information which Google communicates to the public over the Internet cannot be completely dominated by instrumental logic, any more than can public discourse. And so the CJEU applies a balancing test to Google's links that it would not - and should not-apply to Google's processing of personal data gathered from its own customers. ${ }^{381}$

In applying this balancing test, however, the CJEU must navigate the Internet as a domain of actual human meaning. It must determine which links are offensive and which contribute to the public interest. The CJEU in Google Spain seems uncomfortable in this role. Its forays into the significance of communication on the Internet are tentative and uncertain. This is unfortunate: if a legal system cares about the free formation of public opinion, the curtailment of public discourse to achieve social goods, like public safety or public order, requires close judicial supervision.

This is no less true when the state seeks to suppress public discourse to achieve values that we associate with privacy. A state may well believe that public communications that disclose past criminal records should be prohibited to achieve the social objective of rehabilitation. ${ }^{382}$ Balancing the need for rehabilitation against freedom of expression requires a steady judicial hand. Different legal systems may reach different conclusions about how such a balance ought to be resolved, but what ought to be beyond controversy is that there can be no serious judicial review without a clear grasp of the ends that legal regulation seeks to achieve.

At the most fundamental level, what is missing from Google Spain is a firm awareness of the privacy values that the CJEU hopes to realize

381. See Google Spain, supra note 12, para. 81.

382. See, e.g., Charles Arthur, Wikipedia Sued by German Killers in Privacy Claim, GUARDIAN (Nov. 13, 2009), https://www.theguardian.com/technology/2009/nov/13/wikipediasued-privacy-claim [https://perma.cci7HKE-XXCF]; Jennifer Granick, Convicted Murder to Wikipedia: Shhh!, ElEC. FRONTEIR FOUND. (Nov. 10, 2009), https://www.eff.org/deeplinks/2009/ 11/murderer-wikipedia-shhh [https://perma.cc/BRE7-U5DB]; David Kravetz, Convicted Murder Sues Wikipedia, Demands Removal of His Name, WIRED (Nov. 11, 2009), https://www.wired. com/2009/11/wikipedia_murder [https://perma.cc/6RU7-QQK5]. 
by the RTBF it has cobbled together. Google Spain follows consistently neither the logic of bureaucratic rationality nor the logic of social norms. It is uncertain, therefore, what the remedy created by Google Spain is meant to accomplish. This ambiguity will likely be bequeathed to the far more comprehensive and detailed GDPR, whose enforcement is looming in the near future.

No doubt forcing the question of values to the surface will be controversial and difficult, but the responsible construction of public law cannot evade this responsibility. In the context of a decision like Google Spain, we must decide whether we seek to protect data privacy or dignitary privacy. We must create the doctrinal structure appropriate for whichever end we choose.

\section{APPENDIX}

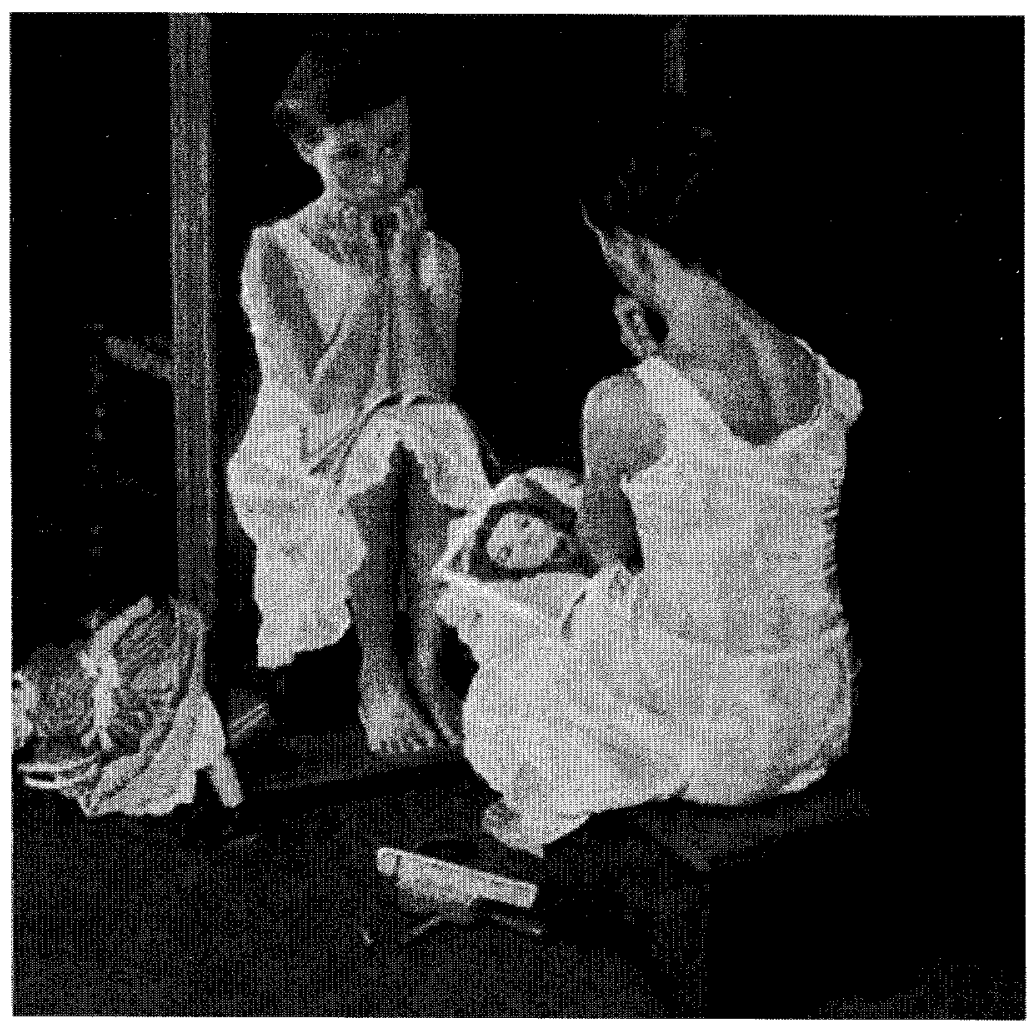

